\begin{abstract}
MANUEL MARTÍNEZ ARTEAGA
Licenciado en Negocios Internacionales e Integración por la Universidad Católica del Uruguay mmartinezarteaga@gmail.com ORCID ID: https://orcid.org/0000-0002-9319-7I2 6
\end{abstract}

Agustín MIMBACAS BLANCO Licenciado en Estudios Internacionales por la Universidad ORT (Uruguay)

agustinmimbacas@hotmail.com ORCID ID: https://orcid.org/0000-0002-6885-3734

Recibido: 25/I0/2021 - Aceptado: 10/1 I/2021

Para citar este artículo / To reference this article / Para citar este artigo Martínez Arteaga, M. y Mimbacas Blanco, A. (202I). Uruguay y la necesidad de modernizar su estructura institucional para desarrollar su estrategia de inserción comercial internacional. ¿Existe hoy una estructura institucional abocada a la inserción económica-comercial internacional del país?. Revista de Derecho, 20(40), 197-276. https://doi.org/l 0.47274/DERUM/40.8

\title{
Uruguay y la necesidad de modernizar su estructura institucional para desarrollar su estrategia de inserción comercial internacional. $¿$ Existe hoy una estructura institucional abocada a la inserción económica-comercial internacional del país? ${ }^{1}$
}

\begin{abstract}
Resumen: En Uruguay existe una estructura institucional dedicada a la inserción económica-comercial internacional, la cual ha estado, en los últimos 30 años, fuertemente influenciada por nuestra presencia en el Mercosur. El diseño institucional de la política comercial externa constituye uno de los pilares sobre los cuales se sostiene una estrategia de inserción internacional de un país. La política comercial externa no puede estar ajena a las instituciones y procesos que permiten darle forma. Importan los contenidos de una política, pero también los aspectos formales que permitan el fluir de esos contenidos. Para un país del tamaño de Uruguay, el desarrollo está íntimamente ligado a cómo se logre insertar en otros mercados.

Además, Uruguay necesita sustentar su inserción económica-comercial en base a acuerdos cuya naturaleza jurídica e institucional le permita desplegar una política comercial externa proactiva y dinámica que impacte, de manera positiva, en la competitividad.

A raíz de los magros resultados que ha obtenido el bloque regional a lo largo de su historia en materia de agenda comercial externa, $y$, a la luz, de un cambio de gobierno en el Uruguay, desde marzo de 2020, se percibe que el país se encuentra en un punto de quiebre que puede generar nuevas oportunidades. Es por eso que, en esta investigación, hemos decidido ahondar en cuál es la arquitectura institucional que tenemos y qué necesidad de modernización y adaptación requiere para poder ser eficientes, dinámicos, proactivos y lograr trabajar de manera coordinada.
\end{abstract}

Palabras clave: política comercial externa, diplomacia comercial, estructura institucional, apertura al mundo, Mercosur.

1 Tesis presentada el 26 de julio de 2021, correspondiente al Máster en Integración y Comercio Internacional (MICI) de la Universidad de Montevideo. Tutor: Embajador Dr. Agustín Espinosa Lloveras. Este artículo representa un extracto de la investigación. El trabajo completo se puede ver en el siguiente link. 


\title{
Uruguay and the need to modernise its institutional structure in order to develop its international trade integration strategy. Is there an institutional structure in place today that is dedicated to the country's international economic and trade integration?
}

\begin{abstract}
Uruguay has an institutional structure dedicated to international economic and trade integration, which has been strongly influenced by our presence in Mercosur over the last 30 years. The institutional design of foreign trade policy is one of the pillars on which a country's international insertion strategy is based. Foreign trade policy cannot be divorced from the institutions and processes that shape it. The contents of a policy are important, but so are the formal aspects that allow those contents to flow. For a country the size of Uruguay, development is closely linked to how it manages to insert itself into other markets.

In addition, Uruguay needs to sustain its economic and trade insertion based on agreements whose legal and institutional nature allows it to deploy a proactive and dynamic external trade policy that has a positive impact on competitiveness.

As a result of the poor results obtained by the regional trade bloc throughout its history in terms of its external trade agenda and considering a change of government in Uruguay in March 2020, it is perceived that the country is at a turning point that can generate new opportunities. That is why, in this research, we have decided to delve into what institutional architecture we have and what need for modernization and adaptation it requires to be efficient, dynamic, proactive, and able to work in a coordinated manner.
\end{abstract}

Key words: foreign trade policy, commercial diplomacy, institutional structure, openness to the world, Mercosur.

\section{Uruguai e a necessidade de modernizar a sua estrutura institucional para desenvolver a sua estratégia de integração comercial internacional. Existe hoje uma estrutura institucional orientada à integração económica e comercial internacional do país?}

Resumo: O Uruguai possui uma estrutura institucional dedicada à integração económica e comercial internacional, que tem sido fortemente influenciada pela nossa presença no Mercosul ao longo dos últimos 30 anos. O desenho institucional da política comercial externa constitui um dos pilares sobre os quais se sustenta uma estratégia de inserção internacional de um país. A política de comércio externo não pode estar alheia às instituições e processos que a moldam. Os conteúdos de uma política são importantes, mas também são importantes os aspectos formais, pois permitem a fluidez desses conteúdos. Para um país do tamanho do Uruguai, o desenvolvimento está diretamente ligado à forma como se consegue inserir em outros mercados.

Além disso, o Uruguai precisa sustentar sua inserção econômica e comercial com base em acordos, cuja natureza jurídica e institucional lhe permita desenvolver uma política comercial externa proativa e dinâmica que impacte, de maneira positiva, na competitividade.

Como consequência dos maus resultados obtidos pelo bloco regional ao longo de sua história em termos da agenda comercial externa, e à luz de uma mudança de governo no Uruguai em março de 2020, percebe-se que o país se encontra em um ponto de inflexão que pode gerar novas oportunidades. É por isso que, nesta pesquisa, decidimos aprofundar a arquitetura institucional que temos e a necessidade de modernização e adaptação requerida para ser eficiente, dinâmica, proativa e capaz de trabalhar de forma coordenada.

Palavras - chave: política comercial externa, diplomacia comercial, estrutura institucional, abertura ao mundo, Mercosul. 
“Tu tiempo es limitado, no lo malgastes viviendo la vida de alguien distinto. No te quedes atrapado en el dogma, eso es vivir como otros piensan que deberías vivir.

No dejes que los ruidos de las opiniones de los demás acallen tu propia voz interior. Y, lo que es más importante, ten el coraje para seguir a tu corazón y tu intuición.

Ellos ya saben de algún modo en qué quieres convertirte realmente."

Steve Jobs. Discurso en la Universidad de Stanford. 12 de junio de 2005.

\section{Introducción}

La pandemia Covid-19 ha venido a confirmar una tendencia que se venía observando en los últimos años, fundamentalmente luego de la crisis financiera global del 2008: nos encontramos en un mundo cada vez más interconectado, pero a la vez, con altos grados de incertidumbre e imprevisibilidad. El mundo experimenta un mayor nacionalismo o proteccionismo a nivel comercial, exacerbado por la profunda crisis que atraviesa el sistema multilateral de comercio.

El futuro del Uruguay está inequívocamente vinculado a cómo se logre insertar en el mundo. Desde nuestros inicios, aunque con distintos enfoques, se ha construido un modelo de crecimiento a través de las exportaciones. La apertura comercial de un país trae aparejado beneficios y desafíos que requieren una permanente adaptación para subsistir de forma competitiva. En términos generales, la literatura ha demostrado que los países que han transitado el camino de la apertura comercial han logrado mejores niveles de desarrollo comparativamente; no niega que se deban enfrentar costos económicos en el corto plazo, pero el resultado tiende a ser siempre positivo, mejor que un camino de proteccionismo comercial. Por otra parte, la apertura comercial per se no logra el desarrollo; es un medio que contribuye al logro de una estrategia más amplia de desarrollo nacional. Y por eso, no se la puede ver como algo aislado, requiere, necesariamente, de otras reformas que acompañen ese proceso de abrirse al mundo.

La aparente falta de consenso que puede percibirse entre los distintos actores nacionales (y a nivel Mercosur) acerca del camino a seguir, en un momento caracterizado por la polarización en distintos temas de la agenda política, dificulta el diseño de una estrategia de inserción económica-comercial que contribuya, positivamente, al desarrollo. La presente investigación pretende contribuir al debate colocando el foco en un área que no ha sido desarrollada en profundidad hasta el momento. Nos referimos al diseño institucional desde el cual se formula e implementa la política pública que implica la inserción internacional. Uruguay ingresó al Mercosur con la firma del Tratado de Asunción en 1991, y desde ahí, fue desarrollando su estrategia. Habiendo cumplido 30 años, el bloque regional tiene la necesidad, una vez más, de relanzarse, sincerarse y flexibilizarse. Se puede hablar de un tiempo "perdido", pero creemos que es mejor considerarlo como un proceso de experiencia acumulada; aprendizaje adquirido que nos permite, hoy, pensar mejor el camino a seguir en el futuro. 
La convicción que nos ha movido a la realización de esta investigación radica en la necesidad de sustentar la inserción económica-comercial del Uruguay en base a acuerdos cuya naturaleza jurídica e institucional permitan desplegar una política comercial externa proactiva y dinámica que impacte positivamente en la competitividad del país. Percibimos, además, que el país se encuentra en un punto de quiebre que genera oportunidades, pero también la necesidad de estar atento a nuevos desafíos. El "desorden mundial comercial" requiere de un análisis profundo que nos prepare para obtener ciertas seguridades que permitan al Uruguay continuar colocando su oferta exportable. El camino iniciado en 1991, del regionalismo abierto, parece haber cambiado de dirección y dado lugar a la bilateralización de las relaciones económicas como fuente de estabilidad.

El diseño institucional de la política comercial externa es uno de los pilares sobre los cuales se sostiene la estrategia de inserción económica-comercial de un país. Abordar un tema de esta naturaleza no resulta sencillo en un país como Uruguay; cuesta mirar en perspectiva y más allá de las personas que hoy ocupan los cargos. Sin embargo, las estructuras impactan en la eficiencia, dinamismo, proactividad y coordinación de las políticas; como sucede en una pequeña empresa, sucede también a nivel de gobierno. Es un gran desafío que requiere de competencias y liderazgos claves. Pensar el diseño institucional debe hacerse dentro del proceso de definición de la estrategia.

Desde el punto de vista metodológico, la investigación la hemos desarrollado en base a dos fuentes específicas de información. Por un lado, hemos realizado un estudio de la bibliografía existente que nos ha permitido desarrollar el marco teórico que presentamos, clarificando conceptos que son el eje del trabajo: i) la política comercial y la visión desde su formulación como política pública; ii) el concepto de estrategia como principio rector de cualquier inserción económica-comercial de un país; iii) la diplomacia económica-comercial como una arista para ejercer esta función en el relacionamiento con otros Estados (y el rol de la diplomacia digital en este momento actual); y iv) el diseño institucional que sostiene la estrategia de la política comercial externa. Sobre estos cuatro ejes desarrollamos el presente trabajo. Por otro lado, hemos complementado esté análisis con entrevistas a distintos actores que son parte, o han sido parte, de la cadena institucional directamente relacionada con la inserción económica-comercial del Uruguay. La experiencia, sus problemáticas, sus planteamientos son una fuente de información imprescindible a la hora de proponer una modernización institucional.

Esta investigación, por tanto, pretende contribuir a la mejora de la estrategia de inserción internacional del Uruguay mediante el análisis y reformulación de su estructura institucional. Se busca que la misma sea capaz de facilitar los procesos de integración comercial, acceso a mercados y atracción de flujos de inversión.

\section{Alcance de la investigación}

Para poder cumplir con el objetivo propuesto, hemos distribuido el trabajo en capítulos que van ofreciendo distintas perspectivas y comprensión del objeto de estudio, hasta llegar a las conclusiones y recomendaciones.

En el capítulo 1, a través del Marco Teórico, situamos el problema de investigación planteado introduciendo una serie de conceptos que acompañan el desarrollo de la 
tesis. Son cuatro ejes que están relacionados entre sí y se vinculan al área del comercio internacional y la formulación de estrategia de inserción económico-comercial.

El capítulo 2 pretende, a través de una mirada histórica, dar un contexto adecuado $\mathrm{y}$ entender los principales acontecimientos y decisiones que Uruguay fue tomando en su constante búsqueda de la mejor estrategia que le permita estar integrado al mundo, ofreciendo su oferta exportable competitiva y de calidad y recibiendo los flujos de inversión que contribuyan al desarrollo. No pretende ser un análisis exhaustivo de la historia puesto que no es el objetivo de la tesis, pero sí es necesario conocer los principales acontecimientos para seguir construyendo un futuro posible.

El capítulo 3 ha sido destinado al análisis de la política comercial externa vigente. Marcada, claramente, por la pertenencia del Uruguay al Mercosur, como la principal plataforma de inserción extracontinental, exploramos el estado de situación actual y cómo no se está cumpliendo los objetivos para los cuales fue creado y se ha convertido, en los últimos años, en una limitante de nuestra apertura comercial sólida, a través de la firma de acuerdos que son verdaderas agendas de desarrollo.

En el capítulo 4 presentamos la estructura institucional vigente en el Uruguay en materia de inserción económica comercial. ¿Cuáles son los organismos que la integran? ¿Qué tareas cumplen? ¿Cómo es la coordinación entre ellos? A su vez, realizamos el análisis de nuestra estructura a la luz del modelo presentado en el marco teórico, con cuatro dimensiones concretas que ayudan a tener una referencia sobre el actual diseño institucional de la política comercial externa.

Con ese mismo modelo, en el capítulo 5, miramos el mundo y la experiencia comparada de Nueva Zelanda y Chile. No fuimos en busca de recetas para replicar en Uruguay, sino para estudiar dos países que han logrado adaptarse, producto de su flexibilidad, a los desafíos que el mundo plantea, llevando adelante una política comercial proactiva, dinámica y con resultados favorables. Ponemos el foco en las claves institucionales que les permitieron llevar adelante esos procesos.

Con toda esta información acumulada, sobre el final del trabajo presentamos nuestras conclusiones, recomendaciones y reflexiones finales buscando dar respuesta a las preguntas que orientan esta investigación y al título de este trabajo que pretende ofrecer un modelo moderno de institucionalidad para llevar adelante la estrategia de inserción económica-comercial que mejor se adapte a la realidad del Uruguay.

NOTA: Luego de haber presentado y defendido esta investigación (en julio de 2021), el Presidente de la República, Dr. Luis Lacalle Pou, anunció en conferencia de prensa ${ }^{2}$ haber recibido un planteo formal por parte de la República Popular China para iniciar un estudio de prefactibilidad como un paso previo al análisis y negociación de un tratado de libre comercio. Esta noticia, a nuestro juicio, viene a reforzar la idea de la necesaria modernización y adaptación de la estructura institucional para poder enfrentar los nuevos desafíos y nuevas oportunidades que se le pueden presentar al Uruguay, al adoptar una estrategia de inserción internacional con carácter más aperturista y flexible.

2 Uruguay Presidencia (2021) Uruguay recibió planteo formal de China para avanzar en la firma de un tratado de libre comercio. Visto en: https://www.gub.uy/presidencia/comunicacion/noticias/uruguay-recibio-planteo-formal-china-para-avanzar-firmatratado-libre (03/10/2021) 


\section{Capítulo 1. Marco teórico}

"El que aprende y aprende y no practica lo que sabe es como el que ara y ara y no siembra."

Platón

Habiendo estudiado y analizado la literatura existente, en el marco teórico de la investigación presentamos cuatro grandes ejes sobre los cuales asentamos el trabajo. Son conceptos relacionados entre sí y se vinculan con el área del comercio internacional y la formulación de la estrategia de inserción económica-comercial internacional, poniendo particular atención en el diseño institucional de la Política Comercial Externa.

Los cuatro ejes son:

a. La política comercial como una política pública;

b. La estrategia como principio rector de una inserción económica-comercial;

c. La diplomacia económica-comercial y el rol de la diplomacia digital; y

d. El diseño institucional como pilar de una estrategia de política comercial externa.

Por un tema de extensión del documento que aquí presentamos, y con el fin de priorizar el objetivo central de la investigación, desarrollaremos únicamente el eje referido a la institucionalidad de la PCE (Política Comercial Externa). En base a este modelo hemos realizado el análisis de la arquitectura institucional vigente en el Uruguay y el análisis de la experiencia comparada en los países seleccionados: Chile y Nueva Zelanda. Antes de ingresar en este cuarto eje, de manera sucinta, queremos presentar los otros tres puntos utilizados en el marco teórico, que podrán ser ampliados en la lectura del trabajo completo.

\subsection{La política comercial como política pública}

Iniciamos nuestra investigación ubicando a la PCE en el ámbito de una política pública que busca responder a la problemática de la inserción económica-comercial del Uruguay.

El avance de la globalización ha generado una cercanía cada vez mayor entre distintas esferas de la gestión pública que anteriormente se abordaban de manera independiente. Esta creciente interdependencia ha complejizado el cumplimiento de responsabilidades por parte de los Estados e incrementado la presión por llevar adelante una gestión eficiente por parte de la administración pública. La necesidad por mayores grados de planificación y coordinación ha generado que rara vez el accionar del Estado se rija por acciones que no formen parte de una estrategia previamente definida. José Luis Aguilar señala:

“...lo específico y peculiar de la política pública consiste en ser un conjunto de acciones intencionales y causales, orientadas a la realización de un objetivo de interés/beneficio público, cuyos lineamientos de acción, agentes, instrumentos, procedimientos y recursos se reproducen en el tiempo de manera constante y coherente. La estructura estable de sus acciones durante un cierto tiempo es formalmente lo específico y lo distintivo de ese conjunto de acciones de gobierno que llamamos política pública." (Aguilar, 2012, p.17) 
El diseño de la política comercial corre por las mismas vías que cualquier otra política pública, sin embargo, es de notar que tanto el diseño como la implementación se verán limitadas por obligaciones asumidas en el ámbito multilateral, regional y bilateral. Las tendencias a nivel multilateral y regional llevan a que la política comercial se trata de una política progresiva, con poco margen para retroceder en cuanto a la liberalización llevada adelante.

Hoy por hoy la política comercial de un país ya no es determinada solamente por cuestiones arancelarias, sino que gira en torno a una plétora de distintas disciplinas, con creciente relevancia de temáticas no arancelarias (UNCTAD, 2018). La ampliación en el número de temáticas abordadas en negociaciones comerciales, así como el creciente número de actores afectados ha generado que el horizonte institucional se amplíe cada vez más.

Ninguna política comercial que no se encuentre basada en un consenso nacional será sustentable en el tiempo. De ahí la importancia de que el gobierno, pero también los distintos actores tengan claros sus intereses y objetivos, de manera de poder diseñar la estrategia y la política comercial externa a llevar adelante. La institucionalidad que el país tenga para poder facilitar este proceso es fundamental.

Como consecuencia de la creciente interdependencia entre políticas estatales, la política comercial se encuentra entrelazada con varias esferas de la administración pública, así como con la estrategia de desarrollo nacional; los puntos de contacto y el solapamiento entre política comercial, política económica, política exterior, política industrial, y política ambiental -entre otras- generan una necesidad adicional de que haya coherencia y coordinación entre todas.

Desde sus orígenes hasta su implementación, la política comercial cumple con todas las características de una política pública. Nace como respuesta a una problemática y en su abordaje influyen tanto factores técnicos como políticos. En el equilibrio entre intereses particulares y pragmatismo es que se encuentran las políticas comerciales exitosas que hacen la diferencia en el desarrollo a largo plazo de un país.

\subsection{La estrategia dentro de la inserción internacional}

La estrategia, a la hora de planificar y diseñar una política comercial externa que favorezca la inserción económica-comercial internacional de un país, se ha tornado, cada vez más, en un punto importante a tener en cuenta. Algunos autores que se dedican a la investigación de estos temas lo han señalado: “...antes de salir al mundo, debemos definir nuestra estrategia país y darnos cuenta del potencial que tenemos - más allá de las dimensiones de nuestro mercado- para insertarnos internacionalmente de forma dinámica e inteligente. Y no titubeante" (Albertoni, 2019, p.29).

El filósofo y político Séneca decía "cuando no sabes hacia donde navegas, ningún viento es favorable". La estrategia busca contribuir a descubrir los mejores vientos que ayuden a llegar a buen puerto. ¿Cuáles son las fortalezas que tiene Uruguay para lograr una inserción comercial internacional exitosa? ¿Cuáles son las debilidades que limitan lograr que esa inserción internacional sea exitosa? ¿Qué entendemos aquí por inserción comercial exitosa? ¿Cómo puede la nación, aportar un valor añadido que sea percibido 
como diferente por nuestros competidores? ¿Qué camino debería transitar el Uruguay para que la apertura comercial genere el tan deseado desarrollo del país?

Desde 1985 a la fecha, cada cinco años, el primero de marzo, el Presidente de la República recién asumido en funciones realiza un discurso ante la Asamblea General del Uruguay ${ }^{3}$. Se trata de un mensaje que ha sido usado de diversas maneras por cada uno de los seis presidentes -aunque ocho fueron las instancias, ya que dos repitieronelegidos desde la restauración democrática, pero que, en el fondo, todos transmiten sus líneas orientadoras para su período de gobierno. Si uno analiza estos discursos podrá observar los distintos enfoques, acentos e importancia que se le fue dedicando al tema de la inserción económica-comercial.

En el siguiente cuadro, se presentan algunas líneas de los discursos presidenciales con relación a la inserción internacional del Uruguay.

Julio María Sanguinetti

(1985-1990)

Luis Alberto Lacalle (1990-1995)

Julio María Sanguinetti (1995-2000)

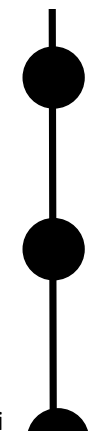

"Este país que fundamentalmente ha crecido siempre, a lo largo de su historia, a través de sus exportaciones y de su búsqueda de mercados internacionales-eso es lo que ha ocurrido en el siglo y medio de su vida independiente-, debe volver a hacerlo con redobladas energías."

Jorge Batlle Ibañez (2000-2005) (2005-2010)

José Mujica (2010-2015)

Tabaré Vázquez (2015-2020)

Luis Lacalle Pou (2020-2025)
"Adecuada respuesta en nuestro entorno a ese tiempo nuevo debe ser la articulación más profunda de la Cuenca del Plata como entidad geopolitica en la cual la coordinación de esfuerzos en emprendimientos de importancia den noticia al mundo de que en esta región se comienza también una transformación y un despertar."

"El proceso de integración, el proceso del Mercosur, impone al Uruguay, precisamente, la búsqueda de espacios de mercado para todos aquellos sectores que han demostrado las mayores capacidades (...) tenemos que actuar con instituciones que tengan la flexibilidad suficiente, la eficacia necesaria para poder acompañar ese proceso con agilidad."

"El Uruguay, país abierto y de vocación internacional, respetuoso de las leyes y de las libertades, no podía menos que integrar desde el primer día-como su Constitución lo establece-el Tratado de Asunción. Hemos crecido en el Mercosur; aspiramos a seguir creciendo en el Mercosur."

"El compromiso con el Mercosur y el carácter prioritario del proceso de integración como proyecto político estratégico en la agenda internacional del Uruguay. (...) el Gobierno que hoy asume quiere más y mejor Mercosur; un Mercosur ampliado, redimensionado y fortalecido."

"Solo déjenme afirmar que, para nosotros, el Mercosur es "hasta que la muerte nos separe" y que esperamos una actitud recíproca de nuestros socios mayores."

"La defensa de la soberanía de los pueblos hará que Artigas, sin caer en un peligroso aislacionismo, sea particularmente cuidadoso y firme en su relación con las potencias de la época."

"Queremos un Mercosur que se plantee objetivos y acuerdos viables (...) que rompa con el encierro." (Rodolfo Nin Novoa al asumir funciones en el Ministerio de Relaciones Exteriores el 2 de marzo de 2015)

"Hay que fortalecer la región, el Mercosur y, al mismo tiempo, lograr flexibilizar el bloque para que cada socio pueda avanzar en procesos bilaterales con otros países.

3 Parlamento Nacional. Asamblea General. Documentos y Leyes. Discursos de Presidentes de la República y Presidentes del Consejo Nacional de Gobierno. https:/ / parlamento.gub.uy/documentosyleyes/discursos/presidentes-rou 
En 1991, Uruguay, al decidir ingresar al Mercosur, tomo una decisión sobre cuál sería la estrategia que quería seguir: un regionalismo abierto que le sirviera de plataforma para insertarse al mundo, siendo parte de un bloque regional con un alto grado de potencialidad. Sin embargo, 30 años más tarde, los resultados no hay sido los esperados y se torna imperioso la revisión de las decisiones tomadas, ahora con una experiencia adquirida que permite realizar una evaluación en base a la evidencia. Y hoy, en varios sectores de la sociedad se observa una mayor conciencia de la importancia que tiene este tema para el desarrollo del país y la necesidad que existe de transformarla. Apertura comercial lleva consigo crecimiento económico y, por lo tanto, posibilidades de desarrollo. Con menos de un año para poder definir su camino estratégico muchas reflexiones y necesarios debates quedaron sin respuestas. No hubo tiempo y se consideró más peligroso quedar fuera (Albertoni, 2019, p.90).

\subsubsection{El modelo de regionalismo abierto}

El concepto regionalismo abierto, si bien se originó en la década de 1970 en el contexto de la cooperación económica de Asia Pacífico, tuvo su auge en los '90 cuando la Comisión Económica para América Latina y el Caribe (CEPAL) lo impulsó. Busca la combinación de una estrategia de liberalización comercial, pero asociada a una integración regional. En un documento elaborado por la CEPAL en 1994 y titulado, `El regionalismo abierto en América Latina y el Caribe: La integración económica al servicio de la transformación productiva con equidad', define al regionalismo abierto como:

"un proceso de creciente interdependencia económica a nivel regional, impulsado tanto por acuerdos preferenciales de integración como por otras políticas en un contexto de apertura y desreglamentación, con el objetivo de aumentar la competitividad de los países de la región y de constituir, en lo posible, un cimiento para una economía internacional más abierta y transparente." (CEPAL, 1994, p.8).

El Dr. Fernández Reyes, en su libro Curso de Derecho de la Integración, estudia el tema del regionalismo y señala:

"Se ha significado como elemento caracterizante, que la apertura y promoción del comercio al nivel del esquema de integración no discrimine el comercio (no se produzca "desviación de comercio" o se construya una "fortaleza comercial"), sino que el acuerdo refleje "lo preferencial", producto de la cercanía geográfica y en ocasiones cultural y social, pero no descuide las realidades internacionales del mercado mundial." (Fernández Reyes, 2013, p.89)

Algunos elementos que el Dr. Fernández Reyes (2013) establece como determinantes para la configuración del "regionalismo abierto" en los procesos de integración:

a. La consagración en los acuerdos -conceptual e instrumentalmente- de una liberalización amplia de mercados que abarque todos los sectores. Vinculo de negociaciones de índole comercial de bienes, con otros temas: servicios, propiedad intelectual, inversión extranjera, medio ambiente, comercio digital, trabajo, entre otros. 
b. La liberalización de los mercados en forma amplia en términos de países, admitiendo la adhesión de otros países en igualdad de condiciones, sin cláusulas arbitrarias, e independientemente de la continuidad geográfica u otro tipo de afinidades.

c. La existencia de normas comerciales estables, previsibles y transparentes, siguiendo las disciplinas comerciales de la Organización Mundial del Comercio-OMC- antes Acuerdo General sobre Comercio y Aranceles (GATT por su sigla en inglés).

d. La admisión de la heterogeneidad, pero sobre la base de la reciprocidad de derechos y obligaciones, sin perjuicio de liberaciones comerciales unilaterales realizadas por algunos países en materia arancelaria o desgravaciones automáticas, por lo que son otros los temas importantes en el contenido del Acuerdo (obstáculos técnicos al comercio, medidas sanitarias y fitosanitarias, por ejemplo).

e. La adopción de las reglas internacionales, dentro de las posibilidades del esquema de integración y según el grado de profundidad y las asimetrías existentes.

El Mercosur es considerado como un seguidor de esta visión de regionalismo abierto: aumentar la competitividad y eficiencia interna como región para lograr una mayor integración con el resto del mundo. Lamentablemente no con los resultados esperados. A 30 años de su nacimiento, donde la ambición fue más grande y la realidad se impuso, y dónde el mundo cambió, Uruguay debería tomar una hoja en blanco y transformar su estrategia para que se adapte a las necesidades del Uruguay de hoy y del futuro. La idea sobre la integración regional planteada por Vachino no se ha llevado a la práctica en forma concreta. Decía:

“[la integración regional] debería llegar a ser el banco de pruebas, y el terreno de experimentación en el camino del aprendizaje y de la práctica, que conduzca a una creciente eficiencia y una mayor flexibilidad para una inserción más plena en el mercado mundial" (Vachino, 1989, p.82)

Al Mercosur le ha costado adaptarse. Hoy, el camino apunta hacia acuerdos comerciales más flexibles (zonas de libre comercio) y no a la lógica de integración profunda (unión aduanera o mercado común). Hoy los tratados de libre comercio son verdaderos acuerdos o agendas para el desarrollo. Van mucho más allá de reducción de aranceles para bienes o servicios, incorporando una cantidad de temas nuevos y muy diversos entre sí: inversiones, propiedad intelectual, pequeñas y medianas empresas (PYMES), regulación laboral, género, compras públicas, ambiente, e-commerce, agricultura, servicios financieros, servicios.

\subsubsection{El camino del regionalismo cruzado}

No se debe asumir que las estrategias de inserción económica internacional sean exitosas solo porque existen (Grugel y Hout, 1999, p.12). Es necesario analizar su desempeño y para eso es importante contar con indicadores claros. Un trabajo realizado por Garzón y Prieto en 2017, ‘Estrategias de inserción económica internacional de Colombia y Brasil: regionalismo cruzado y estrategia de tamaño', incorpora el concepto de regionalismo cruzado. Es el instrumento de política económica exterior más extendido en el mundo en los años recientes. Este concepto desafía la visión tradicional de que la integración 
solo puede darse a nivel regional o a nivel global. "El regionalismo cruzado es un tipo de política económica exterior perseguida por Estados soberanos individuales, los cuales sellan alianzas comerciales bilaterales con otros Estados soberanos situados en diferentes regiones del mundo." (Garzón y Prieto, 2017, p.121). Es una estrategia muy atractiva para países en desarrollo. Permite alcanzar, al menos, 4 objetivos estratégicos que contribuyan a incrementar el bienestar y la autonomía política o soberana en las relaciones internacionales:

- Asegurar acceso a los mercados mundiales;

- Reducir la dependencia económica de un solo socio comercial (diversificación);

- Ganar más control sobre el proceso de liberalización y, por ende, sobre los costos domésticos de ajuste estructural;

- Incrementar el atractivo del país como destino de Inversión Extranjera Directa (IED).

Se trata de una estrategia que está directamente relacionada con la actual situación multipolar del mundo. Existe hoy una heterogeneidad de polos económicos que habilita al país que define la estrategia, mediante una diplomacia económica-comercial proactiva, realizar una selección de países con los que desea ejecutar un acuerdo. La clave pasa por pensar en términos de complementariedad y evitar inconvenientes como los que, por ejemplo, pueden observarse en la negociación con la Unión Europea en materia de agricultura.

El regionalismo abierto se ha convertido en una estrategia que se debilita constantemente porque:

“debería servir para mejorar la posición negociadora de los países miembros y permitirles alcanzar TLC más favorables con otros países y bloques regionales. Sin embargo, las iniciativas del Mercado Común del Sur en el ámbito comercial han sido tímidas y los resultados muy magros." (Garzón y Prieto, 2017, p.129)

Uruguay, no puede desconocer el Mercosur, pero debe evitar continuar enredándose con él, "sin darle la espalda a la región, le permita proyectar sus propios objetivos nacionales sin la necesidad de esperar a que sus vecinos tomen la iniciativa" (Albertoni, 2019, p.31). Recuperar soberanía para poder marcar las direcciones que queramos darle a nuestra estrategia. Sergio Bitar (2016), en un trabajo publicado por la CEPAL y titulado 'Las tendencias mundiales y el futuro de América Latina', habla de la necesidad de buscar una buena combinación de iniciativas. De aquí que resulte fundamental asociar la estrategia a la realidad actual del Uruguay, sus desafíos y su oferta exportable. Qué tenemos para vender, bajo qué calidad y en cuánta cantidad resulta imprescindible conocer para poder realizar esa combinación. Incluso, yendo más allá de los bienes, pensar en términos de infraestructura, tecnología, educación, ambiente, energía.

\subsection{La Diplomacia Comercial para insertarnos en el mundo}

En el proceso constante que llevan adelante los Estados para adaptarse a las nuevas formas de relacionamiento externo que les permita actuar en forma global con el fin de conseguir sus objetivos y defender sus intereses previamente establecidos, el concepto de diplomacia ha ido transformándose y especializándose en determinadas áreas. 
Si bien solemos asociar a la diplomacia directamente al vínculo con el exterior, a las relaciones exteriores -lo cual es cierto-, es una actividad íntimamente ligada a la política interna. Poder llevarla adelante con éxito requiere de conocer los objetivos que persigue el gobierno, la política comercial y estratégica definida, la oferta exportable del país y los intereses de otros actores en el mercado de destino.

A fines del siglo XIX, en un contexto de rivalidades imperiales, la diplomacia económica comenzó a imponerse como un instrumento de política exterior para la proyección de intereses nacionales hacia el mundo. La diplomacia económica es parte de la diplomacia tradicional y ha adquirido una relevancia tan importante, que se ha tornado inseparable. El foco de la diplomacia económica pasa a estar en el comercio internacional, la promoción de las exportaciones y la atracción de inversiones. En un Estado Moderno, ya no se concibe que los países no tengan una estrategia que permita desarrollar también una diplomacia económica.

\subsubsection{Diplomacia Comercial}

Una de las aristas de la diplomacia económica, es la diplomacia comercial. Sin ser lo mismo, son altamente complementarias. Olivier Naray, define la diplomacia comercial como "una actividad desarrollada por representantes de un Estado con status diplomático con el objetivo de promover los negocios entre su país y el país de destino" (Naray, 2008, p.1). Es decir, los gobiernos a través de sus representaciones diplomáticas en los distintos Estados receptor donde se encuentren realizan tareas de promoción del comercio (exportaciones e importaciones) y la búsqueda de inversión extranjera directa para realizar en el Estado acreditante.

La presencia de un cuerpo diplomático profesional y con preparación en el área económico-comercial que sirva de apoyo al sector privado y los intereses del país resulta significativo. Una adecuada coordinación y consenso en la política comercial del Uruguay y su estrategia resulta no solo importante, sino urgente de definir. La calidad de la diplomacia comercial tiene una incidencia directa en la eficacia de una estrategia de inserción internacional de un país.

\subsubsection{Diplomacia Digital}

Vivimos en un mundo hiperconectado. Los procesos vinculados al mundo digital se han fortalecido y, en muchos casos, ha acelerado el uso de este para poder seguir respondiendo a los desafíos y responsabilidades presentes.

La última década del Siglo XX introdujo una verdadera revolución digital. La globalización, no solo económica y política, también se da en el ámbito tecnológico, en la comunicación y la información. Eso ha implicado que todos, incluido los Estados, debieran iniciar procesos de adaptación en las nuevas formas de relacionamiento exterior. Las relaciones internacionales no fueron ajenas a esta nueva realidad naciente y la diplomacia tradicional debió comenzar a ajustarse al nuevo contexto digital.

Es difícil encontrar una definición única de diplomacia digital que sea ampliamente aceptada. Al menos dos son las vías posibles por las que puede ser abordada la diplomacia digital. Por un lado, por la vía de la institucionalidad del Estado, es decir, "en los diferentes usos que los encargados de la política exterior y la diplomacia de este pueden 
hacer de las TICs con el fin de cumplir sus objetivos." Y, por otro lado, desde el punto de vista de la sociedad civil: "las implicaciones que pueden generar sobre la política exterior y el ejercicio de la diplomacia la apropiación social de estas temáticas, a través de las diferentes TICs." (González Parias, 2019, p.10)

La diplomacia digital es uno de los elementos fundamentales para poder comprender la transformación de la diplomacia contemporánea. Existe una clara convicción de que la diplomacia digital sugiere la idea de un trabajo en redes en la que intervienen actores estatales y no estatales, lo que habilita e implica un trabajo más coordinado, necesitado de mayor articulación y más desafiante dado que ha aumentado la disponibilidad de información y se actúa en un entorno de mayor velocidad. Procesar, analizar y lograr una rápida y eficaz respuesta parece ser la combinación perfecta para moverse en este nuevo mundo de la diplomacia digital. Para Uruguay, la diplomacia digital se en convierte en un reto y una oportunidad en materia de política exterior. Es un rato en cuanto debe tomar consciencia sobre la importancia de una buena gestión de toda la información que hoy circula. Pero es una oportunidad, dado su tamaño, para incorporar tecnología de punta que reduzca la distancia entre el ejercicio diplomático y la ciudadanía interesada.

Tres principios rigen la diplomacia digital: flexibilidad, escalabilidad y supervivencia.

“La flexibilidad consiste en la capacidad de conseguir unos objetivos de política exterior mediante el uso de instrumentos no convencionales y la interconexión con otros participantes de la denominada diplomacia en red. La escalabilidad se manifiesta en la capacidad de crecer en forma exponencial sin incrementar los costes de producción, esto es, los recursos destinados a la consecución de los objetivos de política exterior. Por eso, la diplomacia en red necesita la contribución y la cooperación de terceros. La supervivencia pasa por la habilidad de reconfigurarse, buscar aliados y encontrar puntos de encuentros." (Manfredi, 2014, p.347)

\subsection{La estructura institucional de la política comercial externa}

Este cuarto punto es el eje central de nuestro marco teórico, el objeto de estudio de esta investigación. Es aquí donde este trabajo se propone realizar una contribución. El diseño institucional de la política comercial externa es un pilar clave a la hora de pensar en la estrategia de inserción económica-comercial internacional.

Las estructuras formuladoras de políticas públicas que componen la administración pública son producto de un conjunto de normas y reglas que existen en todas las sociedades del mundo. Las instituciones, se caracterizan por determinar el funcionamiento de una sociedad, así como el comportamiento de sus integrantes y varían enormemente de país en país. Según Douglass North, premio Nobel de Economía y uno de los principales proponentes del institucionalismo:

“...las instituciones son las reglas de juego de una sociedad, o más formalmente, son las limitaciones ideadas por el hombre que dan forma a la interacción humana. Por consiguiente, estructuran incentivos en el intercambio humano, sea político, social o económico." (North,1990, p.13). 
Más allá de los resultados diferentes que pueden ocasionar unas u otras instituciones, al igual que las políticas públicas, estas no pueden trasplantarse y aplicarse de manera universal. El éxito de la corriente institucionalista dentro de las ciencias sociales yace en la manera en que han podido vincular a instituciones sólidas, eficientes, y capaces de adaptarse a coyunturas cambiantes, con desarrollo económico y estrategias de desarrollo exitosas.

El continente latinoamericano es un claro ejemplo de cómo instituciones pueden favorecer o condenar determinadas estructuras institucionales, así como políticas públicas. A lo largo de la historia de la región, se ha buscado implementar soluciones "talle universal", sea en el ámbito económico, político o social. Esto no significa que al igual que con las políticas públicas no se pueda aprender de experiencias exitosas, sino que se debe ampliar el abanico de variables al momento de armar un esquema organizacional o diseñar una política.

El éxito relativo propiciado por diferentes estructuras institucionales de la política comercial externa se ha intentado medir mediante distintas metodologías de análisis comparados: algunos estudios se enfocan en una sola variable, mientras que otros son multidimensionales. Entre los primeros se encuentran: Sáez (2005) con `Trade Policy Making in Latin America: A Compared Analysis'; Ehrlich (2007) con 'Access to Protection: Domestic Institutions and Trade Policy in Democracies'; y por ultimo, Mansfield, Milner y Pevehouse (2012) con 'Vetoing Co-operation: The Impact of Veto Players on Preferential Trading Arrangements'.

Entre aquellos con un enfoque multidimensional se encuentra 'Diseños Institucionales y Gestión de la Política Comercial Externa en América Latina' de Jordana y Ramió (2012); 'Anatomía de las Instituciones de la Política Comercial Externa' de Zelicovich (2020); y 'Evaluación Institucional de la Política Comercial Externa' de Roberto Bouzas (2020).

Todas estas investigaciones deciden abordar la institucionalidad mediante distintas variables, algunas macroscópicas, y otras haciendo hincapié en elementos más puntuales. Sin embargo, el punto en común entre todas es que hay un verdadero interés académico por detrás de la formulación de la política comercial, y particularmente, en qué tipo de arreglos institucionales son los que demuestran tener mayor éxito.

La variable institucional es un aspecto más a tener en cuenta. Per se no garantiza el éxito de una política comercial externa, pero si las características del proceso y, por tanto, los procedimientos establecidos para gestionar y administrar, afecta los resultados. Sí hemos notado que, a pesar de la literatura existente y el verdadero interés que ha despertado, desde el punto de vista académico, no se le ha prestado la suficiente atención en Uruguay. De hecho, en algunas entrevistas que realizamos se nos llegó a señalar que este no era un aspecto problemático, y, al consultar sobre las variables que consideran importantes para éxito el de una política comercial, ninguno de los entrevistados señaló el aspecto institucional.

\subsubsection{El modelo de análisis de la Política Comercial Externa que seguiremos}

Habiendo evaluado los distintos modelos presentados, en nuestra investigación optamos por seguir la metodología que presenta Roberto Bouzas (2020), complementada 
en algún punto con la implementación que ha realizado la Dra. Zelicovich (2020) en algún estudio de caso.

Antes de presentar la metodología, queremos aportar la definición de política comercial externa que plantea Bouzas:

“El conjunto de normas y prácticas que tienen como objeto primario afectar el intercambio internacional de bienes y servicios. De este modo, el estudio del proceso de formulación e implementación de la PCE se abordará a través del análisis de las reglas del funcionamiento del complejo institucional encargado de formular e implementar las prioridades, estrategias y acciones en materia de impuestos a la exportación/ importación, cuotas y licencias de importación/exportación, procedimientos aduaneros, medidas de defensa comercial, incentivos y medidas de promoción y otras regulaciones internas que afectan el movimiento internacional de bienes y servicios (como las normas y los estándares). El desarrollo de las negociaciones internacionales que resultan en modificaciones de estas prácticas también se incluirá como parte del complejo de formulación e implementación de la PCE." (Bouzas, 2020, p.4)

Esta visión de Bouzas, a nuestro juicio, se complementa muy bien con la presentada por Zelicovich (2020):

el ejercicio de la capacidad de formulación de las prioridades, estrategias y acciones sobre estos temas (aquellos que se tienen incidencia en el comercio exterior y la inserción económica-comercial de un país); en el desarrollo de las negociaciones internacionales -tanto multilaterales como regionales y bilaterales-; en la implementación de los instrumentos y decisiones que resulten de las dos anteriores; y en las acciones de promoción del comercio exteriores y de las inversiones extranjeras directas (IED) (p.8).

'Distribución de competencias y organización institucional: normas y prácticas', así se titula la metodología que presenta Bouzas y que pretende lograr que el investigador identifique los principales rasgos de la organización y de la gestión de la política comercial externa en el caso de estudio que esté realizando. Para ello, propone el siguiente abordaje:

a. Distribución de competencias entre los distintos poderes del Estado;

b. Ubicación, formato institucional y características de la autoridad principal (o "líder") en el espacio político pertinente;

c. Las agencias públicas subsidiarias que participan en ese espacio de política; así como la modalidad de coordinación/interacción que predomina;

d. Modalidad de participación/intervención de los actores privados relevantes (organizaciones empresarias, sindicatos, organizaciones de la sociedad civil, academia) en el proceso de formulación e implementación de la política comercial externa. Esto incluye la transparencia y los mecanismos de consulta.

La distribución de atribuciones entre los poderes del Estado, así como los mecanismos de cesión, transferencia y/o coordinación de las competencias, principalmente entre el Poder Ejecutivo y el Poder Legislativo constituye una variable de enorme relevancia tomando en cuenta la democratización relativa al diseño de la política comercial. 
Zelicovich (2020) menciona que "el rol del Legislativo puede ampliar o restringir los márgenes de maniobra" del Poder Ejecutivo, así como "habilitar canales de acción para actores no estatales" (p.10). De la misma manera, el Poder Legislativo suele contar con la competencia básica de aprobar y promulgar o no un acuerdo, poseyendo poder de veto sobre cualquier compromiso comercial negociado.

Por su parte, dentro del Poder Ejecutivo, puede haber una concentración o descentralización de atribuciones. Por lo general, existe una autoridad principal o "líder" quien, por mandato legal o constitucional, es el encargado de llevar adelante los principales procesos dentro de la política comercial; sin embargo, esta agencia no trabaja de manera unitaria, sino que depende de otras agencias y actores.

Dependiendo del grado de fragmentación del liderazgo de la política comercial externa, Bouzas señala que las estructuras pueden tener "competencias concentradas" (existencia de un ministerio "líder"), "competencias modulares" (liderazgo compartido entre dos ministerios), o "competencias dispersas" (política comercial coordinada entre más de dos ministerios). La fragmentación institucional no es sinónimo de ineficacia, sino más bien la demanda de coordinación y articulación.

En este punto, es importante destacar las agencias de promoción de exportaciones y las inversiones. Es necesario identificar el formato jurídico y la distribución entre las agencias responsables. Un primer aspecto será considerar si las dos funciones se encuentran agregadas en una misma agencia o no. Y un segundo aspecto, referido al formato jurídico-administrativo, distingue tres modelos alternativos: i) la "dependencia ministerial" (los programas de promoción se gestionan desde una o más unidades de uno o más ministerios); ii) la "agencia estatal autárquica" (las tareas de promoción se llevan adelante en el marco de una o más agencias independientes con autonomía); y iii) la "agencia mixta público-privada" (el gobierno y el financiamiento de la o las agencias son compartidos por el sector público y privado). Para Bouzas, identificar cuál es el modelo que predomina es importante porque tiene implicancias en la organización y el funcionamiento de las agencias.

En cuanto a los esquemas de coordinación, el proceso de diseño, decisión, comunicación, implementación, y monitoreo de cualquier política pública está sujeto a una determinada estructura institucional compuesta por un mayor o menor número de actores; las relaciones que estos actores tienen entre sí sean gubernamentales o de la sociedad civil, es lo que definirá en gran medida el éxito de la política elaborada. Hoy en día la coordinación y cooperación entre agencias es un elemento esencial para evitar asimetrías de información, así como para reducir la duplicación de funciones y contribuir a la generación de consensos en torno a la política pública en cuestión.

Diseños institucionales con ámbitos definidos de coordinación, sean formales o informales, son determinantes para cualquier política. La metodología de Bouzas, basándose en Peters (2018, p.11-12) identifica tres posibles esquemas de relacionamiento y coordinación: "jerárquica", "colaborativa", y de "redes", dependiendo de la rigidez y formalidad de las normas que vinculan a los actores involucrados. La modalidad "jerárquica" cuenta con instrumentos como los procesos presupuestarios, los comités interministeriales y las figuras como los "superministros". El modelo "colaborativo", se apoya en la capacidad de las agencias involucradas para brindar una mirada compartida 
sobre los problemas a resolver. Demanda tiempo para construir un entendimiento común e identificar cómo resolver los posibles conflictos emergentes de distintos intereses, perspectivas y tradiciones institucionales. Por último, la coordinación por "redes", se da a través de la interacción entre funcionarios de manera informal, buscando resolver los problemas con cierto nivel de coordinación, pero sin contar con los canales establecidos o, aún establecidos, sin un funcionamiento adecuado.

Al igual que para cualquier política pública, la política comercial necesita tener la mayor base de apoyo posible en todos los sectores de la sociedad al ser esta la principalmente afectada por cualquier negociación que suceda. Para esto, es necesario que haya una comunicación extensiva y que existan mecanismos de acceso por parte de actores de la sociedad civil, tanto a la información, como al proceso de deliberación. Un aspecto muy importante aquí es, producto del avance de los acuerdos profundos, que involucran cada vez más temáticas y, por tanto, más actores, el grado de transparencia y acceso oportuno a la información sobre el proceso de formulación e implementación de políticas que faciliten las agencias de gobierno.

Según Bouzas, la participación de actores no estatales dependerá tanto del grado de organización e injerencia que tengan estos, así como el grado de apertura a su participación existente dentro del arreglo institucional de la política comercial externa. Apoyándose en la taxonomía propuesta por Hoking (2004), señala la existencia de tres posibilidades: formato de "club" (participación informal y marginal de actores no estatales, adoptando el formato tradicional de lobby); formato de "club adaptado" (se amplía la participación hacia sectores privados cuyo apoyo e información es imprescindible debido al déficit de conocimiento e información del sector público, continuando siendo un número "exclusivo" de actores. Se puede dar mediante mecanismos formales e informales); y modelo de "multistakeholders" (participación ampliada de actores no estatales en búsqueda de consensos. Aunque normalmente se acompaña de un mayor grado de formalización, no necesariamente precisa ser a través de mecanismos formales). 


\title{
Capítulo 2. Una aproximación a la inserción comercial internacional del Uruguay desde una perspectiva histórica
}

\author{
"Mirar el pasado es necesario. \\ Construir para el futuro es la tarea."
}

Carlos Quijano

La historia de un país cumple un rol fundamental que contribuye a comprender de dónde se viene, cómo se ha llegado al presente y, sobre todo, nos permite ser capaces de saber a dónde vamos y qué futuro queremos y podemos construir. Conocer la historia del Uruguay, y particularmente en este caso, su relacionamiento con el resto del mundo es importante para seguir construyendo hacia adelante. Fuimos a la historia para rescatar ese carácter aperturista que nos caracterizó desde los inicios y marcó nuestro destino. No se trata de un análisis exhaustivo sino de buscar criterios sólidos y fundados para tomar las mejores decisiones de cara al futuro.

Independientemente del momento histórico en el que uno se ubique, la inserción económica-comercial del Uruguay siempre ha estado condicionada por una serie de elementos inamovibles que la han acompañado desde antes de su nacimiento como Estado soberano. Se tratan de circunstancias atemporales que en mayor o menor medida han incidido en los caminos recorridos a nivel de nuestra política comercial, yendo desde nuestra posición geográfica, hasta el número de habitantes por kilómetro cuadrado.

\subsection{Ante de ser un Estado-Nación independiente}

El proceso que culminó con la primera Constitución de la República Oriental del Uruguay en 1830 estuvo precedido de años de revolución, luchas por el dominio de la zona y deseos de autonomía o independencia. La figura de José Gervasio Artigas emerge hacia fines del siglo XVIII como un líder militar y político. Es difícil situarlo con un pensamiento económico propio. Al decir de Ramón Díaz, en su libro Historia Económica de Uruguay, "...testimonian más que nada su herencia cultural prácticamente incontaminada, encarnada además en un temperamento concordantemente apasionado, y la raigambre popular, o populista, de su orientación política." (Díaz, 2003, p.71)

Ya erigido como jefe de los orientales, en 1815, Artigas dicta el Reglamento General de Aduanas según el cual reduce la tarifa de importación para productos de consumo popular -tabaco negro y azúcar- y para los rubros considerados imprescindibles en la época. A su vez, el Reglamento subía a 40\% la tarifa de los bienes que competían con la industria local como el calzado o la ropa confeccionada. Con este Reglamento General de Aduanas, Artigas, sentó las bases de lo que fue una política comercial externa de la época. En base al contexto en el que se encontraba, su estrategia -o la que imponía la tradición española en ese tiempo- fue la promoción del mercantilismo.

Otro suceso de esta época fue en julio de 1817 cuando Artigas inició tratativas con los representantes de Su Majestad Británica, para acordar un tratado de comercio. El tratado fue firmado el 2 de agosto de 1817 -a menos de un mes de haber iniciado las negociaciones- y suscrito por los ingleses el día 8 de agosto. Constaba de 6 artículos, bajo 
tres principios claros: la libre navegación de los ríos; la libertad de comercio y la seguridad de las personas y de sus propiedades en los territorios y puertos que reconocían la jefatura de José Artigas, Protector de los Pueblos Libres. Este Convenio, que fue ratificado 18 días después, firmado por el comodoro William Bowles, es conocido como el Convenio de Purificación, y marcó el inicio de las relaciones con otros pueblos de América y de Europa. La firma de este convenio es considerada hoy como el primer tratado de libre comercio que firmó Uruguay. Generó, además, que Estados Unidos le pidiese al jefe de los Orientales, igual trato que con los ingleses.

\subsection{El Uruguay naciente a la vida independiente}

En 1828 se firma la Convención Preliminar de Paz entre el Imperio de Brasil y las Provincias Unidas del Río de la Plata. Allí se acordó, en forma definitiva, la independencia de la Banda Oriental y el surgimiento de un nuevo Estado, el Estado Oriental del Uruguay -que luego pasaría a ser la República Oriental del Uruguay-. Este nuevo país que nace trae consigo una historia y una gestación compleja y, cuyo proceso de maduración, es muy posterior a su nacimiento, incluso, podríamos señalar que se continúa construyendo hoy en día.

El Uruguay nació a la vida independiente como una nación con una marcada vocación internacional. No porque se haya planificado de esa manera, sino porque la viabilidad del territorio como país independiente así lo exigía. A diferencia de nuestros vecinos, el mercado nacional jamás fue suficiente para un desarrollo económico sostenible a largo plazo, y así se demostró con el fallido ciclo de sustitución de importaciones. Nuestro país fue, es y siempre será una economía pequeña, y como consecuencia de esto, un tomador de precios a nivel mundial.

Estos primeros años de formación, todavía están caracterizados por una debilidad externa como país, producto de su inestabilidad interna y porque sus vecinos aún no aceptaban el nuevo estatus de país independiente. Es a partir de 1865, que el Uruguay comienza a procesar "los cambios económicos, sociales, politicos y culturales, que le significan abandonar estructuras arcaicas y asumir la modernidad (...) el Uruguay fue capaz de desligarse del entramado regional y asumir su propia historia y su propio destino." (Arteaga, 2018, p.73)

\subsection{Entre la modernización, las reformas y las guerras mundiales:} 1870-1945

La década de 1870 es el inicio de una época en la que Gran Bretaña adquiere una relevancia importante dentro del sistema económico internacional. La Dra. Clemente (2005) señala que la inserción internacional de Uruguay a partir de esa fecha se caracterizó por: i) una dependencia casi exclusiva del mercado británico para las exportaciones de Uruguay; ii) endeudamiento externo; y iii) en relación con la región se comienza a aplicar la llamada diplomacia pendular.

El Uruguay que nace al siglo XX implica un punto de inflexión. Se terminan las guerras civiles que habían caracterizado al siglo anterior y se comienza a construir una república más pacífica, caracterizada por el respeto a la Constitución y las leyes. Sin embargo, "...desgraciada -y una vez más- sorprendentemente, la paz interna y externa de que 
la República disfrutó en lo sucesivo no desembocó en una fase más dinámica de la economía." (Díaz, 2018, p.252)

En materia de política internacional, los comienzos del nuevo siglo registran una política exterior del Uruguay más proactiva. La estabilidad institucional permitió llevar adelante un conjunto de reformas en el Estado que sustentaron la posibilidad de pensar una política exterior dinámica y propositiva. Uruguay ingresa al concierto internacional y se inserta en foros multilaterales mundiales y continentales. Seguramente consciente de su tamaño pequeño, pero sin complejos, Uruguay inicia una larga tradición en la práctica de la política exterior y un principio fundamental y básico de la vida diplomática: estar presente en los lugares que hay que estar.

En 1912, Luis Alberto de Herrera publica su famosa obra El Uruguay Internacional. En ella expresa sus principales líneas de pensamiento. Uruguay como un país pequeño, limitando con dos potencias: "Grábese en su pensamiento la convicción de que la República, por ser pequeña está abocada a riesgos permanente; que esos riesgos aumentan si se piensa que enormes limitrofes la oprimen" (Herrera, 1912, p.9), en donde el interés de los vecinos está lejos de coincidir con los intereses de nuestro país. Para Herrera, era indispensable que, a la base de una correcta política externa, existiese unidad nacional al interior del país, "sin armonía doméstica será estéril el ensayo de una gran política internacional." (Herrera, 1912 , p.10) Uruguay debía contar con una diplomacia sólida y con una política exterior de país, que mirara más allá en el horizonte.

La década de 1920, que culmina con la crisis de 1929, conocida como la Gran Depresión, fue una década de prosperidad mundial bastante generalizada que Uruguay supo utilizar a su favor. El Uruguay "pequeño país modelo", al decir de Batlle Ordoñez, vivía un tiempo de paz. Se había logrado llevar adelante transformaciones que solamente fueron posibles por el período de modernización y prosperidad, que se había intensificado a partir de 1876.

Al cumplirse los cien años de la primera Constitución de la República, el país se encontraba con una política económica opuesta al paradigma liberal que había dominado gran parte del siglo XIX, lo cual repercutió en la política comercial externa del Uruguay. Un nuevo orden económico internacional emergía luego de la crisis de 1929. Hubo un claro retorno del proteccionismo, la política monetaria era inestable y las grandes potencias contribuían a crear un clima de incertidumbre. Tanto fue así que, 10 años más tarde, el mundo estaba, nuevamente sumergido en una Guerra Mundial. En América Latina, la política comercial externa se caracterizó por la sustitución de importaciones y la búsqueda de nuevos mercados para diversificar las relaciones exteriores.

En Uruguay, el control de cambios aparece en mayo de 1931 como manera de defender el valor del peso y evitar la salida de divisas. Progresivamente irá ampliando su injerencia en la economía hasta convertirse en una herramienta trascendental para el impulso del nuevo modelo de desarrollo estatocentrico. Las políticas cambiaria y comercial quedan definitivamente ligadas como un medio para el desarrollo económico del país. Se busca la generación de superávits en la balanza comercial para generar productos con mayor valor agregado y mayor contenido industrial. Esta lógica de restar las exportaciones e importaciones y presentar como un logro cuando el saldo de la balanza comercial es mayor a cero, implicó un cambio de mentalidad dañino para el Uruguay. El comercio 
exterior en su totalidad es fundamental para un desarrollo económico sostenible, no solamente las exportaciones.

En 1939 estalla la Segunda Guerra Mundial. La política exterior del Uruguay pone el foco en los temas de seguridad y defensa, máxime cuando hubo un episodio en la costa uruguaya cuando el acorazado alemán Admiral Graff Spee se enfrentó a tres cruceros británicos. Para Uruguay, país productor de alimentos, la Segunda Guerra Mundial implicó abastecer, sobre todo al Imperio Británico.

Terminada la Segunda Guerra Mundial, en 1945, el hecho más significativo fue la creación de la Organización de las Naciones Unidas en la Conferencia de San Francisco. El Uruguay, que se había mostrado con una política nítidamente pro-aliada, sufrió el ocaso del imperio británico, reflejado en el Convenio de Pagos de 1947 con "...el retiro de sus inversiones y el abandono de sus empresas (agua corriente, transporte tranviario y ferrocarril). El vacío que dejó la decadencia británica fue sustituido por el ascenso de Estados Unidos como potencia hegemónica de Occidente." (Arteaga, 2018, p.169).

En materia institucional, se comienza a percibir una de la de las grandes dificultades que es posible percibir incluso en nuestros días. Nos referimos a lo que la Dra. Clemente (2005) menciona como el proceso de toma de decisiones en materia de inserción internacional:

El proceso de toma de decisiones adquirió complejidad creciente con la participación de entidades diferentes al Ministerio de Relaciones Exteriores: el Banco de la República y el Ministerio de Hacienda asumieron un rol protagónico en las negociaciones comerciales y en los acuerdos sobre deuda externa. Por otra parte, se registró la irrupción de múltiples actores de la sociedad civil, muchos de los cuales contaban con niveles altos de calidad de información, con proyectos para incidir en la formulación de políticas de parte del gobierno y con capacidad relativa de incidencia ( $p .29)$

\subsection{Uruguay entre la Segunda Guerra Mundial y la creación del Mercosur}

Terminó la Segunda Guerra Mundial y el mundo cambió. Nos movimos hacia un mundo bipolar con dos grandes bloques que tuvieron como eje la guerra fría. A nivel comercial, en 1947, se creó el GATT (Acuerdo General sobre Aranceles y Comercio), el cual rigió el comercio internacional hasta la creación de la OMC (Organización Mundial del Comercio) al cierre de la Ronda Uruguay, en 1995. Uruguay, fiel a su tradición de apostar por un sistema multilateral sólido, se incorporó formalmente al GATT en 1953, y a su vez, había sido firmante de la Carta de la Habana en 1948 que promovió la creación de una Organización Internacional de Comercio. A nivel regional en 1960 se crea la Asociación Latinoamericana de Libre Comercio (ALALC). La ambición de este proyecto, que pretendía crear un mercado común en diez años, sumado a la inestabilidad política generalizada, hizo que fracasara y tuviera que firmarse un nuevo Tratado de Montevideo, en 1980, que creó la Asociación Latinoamericana de Integración (ALADI) con un enfoque más pragmático y acorde a la coyuntura regional. 
Durante la presidencia de Luis Batlle Berres se produjo el mayor crecimiento de las industrias dinámicas, producto de la política proteccionista que se llevó adelante. La estrategia que se utilizó comprendía tres tipos de normas:

las que otorgaban exenciones o disminuciones tributarias a la importación de la maquinaria industrial (para la ampliación o modernización de equipos) o de materia prima; las que restringían o prohibían el ingreso de productos extranjeros competitivos; y la política de subsidios a través de primas de producción o por mecanismos de cambios múltiples (Arteaga, 2018, p.174).

En paralelo, se produjo un estancamiento en el sector agrícola-ganadero. El proteccionismo aplicado en el mundo, luego de la Segunda Guerra Mundial, permitió que Estados Unidos lograra una gran expansión agrícola y Europa se recuperara. Esto perjudicó directamente a países, como Uruguay, que son productores de materias primas y alimentos.

Con la llegada del Partido Nacional al poder, en 1959, se intenta dar un giro liberal a nivel de política económica y comercial del país mediante la Reforma Cambiaria y Monetaria ideada por el Cr. Juan Azzini, entonces ministro de Hacienda. El Contralor de Exportaciones y el control de cambios son suprimidos al tratarse de dos mecanismos, que a lo largo de sus décadas de existencia, funcionaron semi-exitosamente en una parcial industrialización de nuestra matriz económica, pero generando amplias distorsiones a nivel de inventivos de los agentes económicos.

Así como la década de 1870 había significado el comienzo del Uruguay moderno y próspero, cien años más tarde, la década de 1970 registra la época más oscura de la historia reciente del Uruguay. Luego de años caracterizados por agitación social, agresión al Estado por parte de grupos de guerrilla urbana, en 1973 se produce un quiebre institucional, con la disolución de las cámaras del Poder Legislativo. Le siguen al país doce años de un período de dictadura cívico-militar.

El año 1974 también estuvo marcado por la negociación y firma del Convenio Argentino-Uruguayo de Cooperación Económica (CAUCE). Tiempo más tarde, Uruguay firmó el Protocolo de Expansión Comercial (PEC), con la República Federativa del Brasil. La firma de estos dos acuerdos con Argentina y Brasil, son considerados como un antecedente directo de la creación del Mercosur. Argentina y Brasil iniciaron un proceso de acercamiento que, para Uruguay, eran un llamado de atención.

La década siguiente -1980-, marca política e institucionalmente, el comienzo del fin del período dictatorial tanto en Uruguay como en los demás países de cono sur. Uruguay necesitaba recuperar su prestigio en las relaciones internacionales y esa fue la tarea del entonces Presidente de la República Julio María Sanguinetti y el Ministro de Relaciones Exteriores, Cr. Enrique Iglesias. La política exterior que allí comenzaba a desarrollarse se construía sobre la base de un consenso entre todos los partidos políticos que tenían representación parlamentaria, lo que constituyó una verdadera política exterior de Estado. Tal vez, la única que se haya conformado con éxito desde el retorno de la democracia en 1985. Se afianzaba la participación de otros actores gubernamentales y no gubernamentales. Desde el punto de vista económico-comercial, la política exterior 
de Uruguay observaba los pasos concretos que Argentina y Brasil daban, ahora sí, en forma decidida, en busca de una mayor integración bilateral. Pero, al mismo tiempo, respondiendo a su tradición, en el sistema multilateral de comercio trabajaba por un comercio libre, que dejara a un lado las discriminaciones y subsidios, sobre todo agrícolas, que el mundo desarrollado adoptaba. No fue menor para el Uruguay, que la última ronda del GATT se iniciará, en 1986 en Punta del Este. El primer gobierno que nació al nuevo Uruguay democrático buscó crear espacios para que el exportador pudiera desarrollar su actividad. El pragmatismo del Canciller Iglesias hizo que, el Uruguay, tuviese en esos años, una estrategia de apertura comercial sin restricciones.

En materia institucional, se produjo una reestructura en el Ministerio de Relaciones Exteriores con la creación de Direcciones Regionales y la reorganización de las Direcciones Generales para Asuntos Económicos, Políticos y Culturales. A su vez, la estructura orgánica se complementa con la Dirección de Organismos Internacionales y la de Asuntos Limítrofes, Marítimos y Fronterizos.

\subsection{Los primeros años del Mercosur}

El 26 de marzo de 2021, el Mercosur cumplió treinta años. Un tiempo prudencial para evaluar el camino recorrido y repensar y redefinir nuestra estrategia de inserción internacional, ahora con experiencia acumulada. Está claro que los resultados que se esperaban no se han concretado. Y en particular, en lo que refiere a la agenda externa del Mercosur pocos e insignificantes avances se han logrado para el beneficio del Uruguay.

Albertoni, en su último libro 'Uruguay como solución. Su inserción internacional: cuando lo importante se transforma en urgente', analiza a Uruguay y su estado actual de inserción internacional. Pero es interesante, un capítulo previo en el que analiza los tiempos inmediatamente anteriores al ingreso del país al Mercosur. Allí, consultado el Embajador Arteaga sobre este punto, le señaló:

El ingreso [de Uruguay] al Mercosur lo convirtió en prisionero del sistema regenteado por los dos socios grandes. Fue algo no previsto, pero si se estudiara mejor la historia de Brasil no nos hubiera resultado extraño. La historia de la política exterior de Uruguay nos enseña las debilidades y fortalezas del país. Una de sus principales fortalezas es el apego del Uruguay al derecho internacional y a los acuerdos pactados. Eso lo hizo un país serio y confiable. Sin embargo, en el Mercosur eso no fue suficiente. En algún momento Uruguay se sintió avasallado, lo que le permitió desarrollar una gran capacidad de resistencia. El hecho es que Uruguay está llegando muy tarde a encauzar su necesario proceso de inserción comercial y hoy día se encuentra muy solo en la región latinoamericana o sudamericana. El pasado nos enseña que hay que tejer nuevas relaciones cuanto antes, sea por el camino bilateral o multilateral (Arteaga, 2018, p.87)

La incorporación de Uruguay al Mercosur, sin duda, constituyó el tema de política exterior más relevante del período de Luis Alberto Lacalle. Representó un cambio radical en su política comercial. Y, seguramente, haya sido la decisión de inserción económicacomercial más importante desde que nació como país independiente. Lo que no existió en Uruguay fue la posibilidad de debate y análisis más profundo sobre la decisión de ingresar al Mercosur. Es cierto, contó con un respaldo casi unánime en el Parlamento 
Nacional. Solo un legislador del Frente Amplio, de los 130 que conforman ambas cámaras, voto en contra. Lo cierto es que parecía bastante claro que este proyecto era el único camino posible para la inserción internacional del Uruguay.

En entrevista realizada al Ec. Hodara (2021), quien fuera Director General de Comercio de 1985 a 1990, al consultarlo sobre el ingreso al Mercosur, nos señaló:

Lo que se estaba poniendo a votación (del Parlamento) era si íbamos a entrar a una Unión Aduanera con Argentina y Brasil como socios, sabiendo que muchas veces no han cumplido sus promesas. ¿Cómo se llegó a tal grado de acuerdo? Había intereses dispares que miraban al Mercosur con esperanza por aspiraciones diferentes: el sector industrial de Uruguay, por ejemplo, veía como en la economía los aranceles bajaban y por miedo a que siguieran bajando, se vieron motivados a apoyar el ingreso al bloque. Otros señalaban que había que entrar porque esto iba a ser la reforma que nos iba a obligar a cambiar todo lo que tenemos mal. Nos va a obligar a cambiar el Estado, la Seguridad Social, la Educación. Eso hizo que los números de aprobación fueran unánimes. Y terminó opacando cualquier gran discusión.

El comercio es un verdadero vaso-comunicante entre los países. Como vimos con anterioridad, Uruguay tomó decisiones que lo llevaron a aislarse del resto del mundo durante el período 1931-1974. Luego, también por decisiones propias decidió abrir nuevamente su economía. Ingresar al Mercosur fue optar por una apertura selectiva con Argentina, Brasil y Paraguay. El deseo era que fuese una plataforma para acercarse al mundo en conjunto. Sin embargo, el tiempo ha mostrado lo contrario y la distancia de Uruguay con el mundo, en tiempos de hiperconexión, a nivel comercial, parece ser cada vez más distante.

Ingresar al Mercosur también implicó un cambio en la estructura institucional que buscó crear canales para que distintos sectores puedan expresar sus demandas. Se crea un grupo de trabajo integrado por técnicos del Ministerio de Economía y Finanzas, Relaciones Exteriores, Ministerio de Ganadería, Agricultura y Pesca y Ministerio de Industria, Energía y Minería y el sector privado. El gobierno jerarquizó organismos vinculados a sectores como lácteos, granos y arroz. Dentro del organigrama del Poder Ejecutivo se observaron modificaciones.

Uno de sus asesores [del Presidente] pasó a encargarse de la problemática de la integración y la Oficina de Planeamiento y Presupuesto comenzó a tener rango ministerial, incluyendo en una de sus direcciones la Política de Integración. A la vez, el Ministerio de Industria, y el de Ganadería, Agricultura y Pesca jerarquizan direcciones de su estructura vinculada al proceso (Fernández Luzuriaga y Ferro Clérico, 2004, p.9).

Wilson Fernández Luzuriaga, en su trabajo `Los inicios de la Política Exterior en la Actual Administración', referida al segundo gobierno del Dr. Julio María Sanguinetti, señala que:

Actualmente dentro del propio Poder Ejecutivo, un número creciente de ministerios, agencias, comisiones con carácter permanente, comisiones "ad hoc" y otras entidades buscan influir en el terreno internacional, coexistiendo con la propia Cancillería. En este sentido los ministerios de economía y los bancos centrales han adquirido un rol 
tan trascendente en la negociación que algunos autores mencionan la existencia de diplomacias paralelas en el plano económico. Esto último hace que, muchas veces, se perciban diferencias en los enfoques de relacionamiento exterior entre el sector económico del gobierno y el Ministerio de Relaciones Exteriores (Fernández Luzuriaga 1998, p.7).

A nivel del MRREE (Ministerio de Relaciones Exteriores), durante este período de gobierno 1995-2000, se concretó la creación de la Dirección General de Integración y Mercosur (vigente hoy en día) y la Dirección de Promoción Comercial, creada a partir de la unidad que llevaba ese nombre. Su objetivo principal era constituirse en un canal de inserción para empresarios y/o exportadores nacionales. Esto coincide, además, con el asumir un rol más "comercial" por parte de las Embajadas.

La constante mirada hacia el exterior ha llevado a que el comercio internacional siempre fuera un elemento fundamental de la estrategia de desarrollo nacional a largo plazo. El acceso a mercados ha sido, y continúa siendo, un constante desafío para las autoridades gubernamentales y el sector exportador del país. La contracara lógica de ser un país exportador de bienes intensivos en recursos naturales es que Uruguay ha dependido del comercio para la compra de bienes intensivos en factores productivos carentes a nivel nacional: capital y mano de obra.

Uruguay también ha sido "prisionero" de su posición geográfica. Esta ha condicionado nuestra visión del mundo, así como con quiénes y de qué manera interactuamos. Encontrarnos entre dos mercados exponencialmente mayores al nuestro ha generado que históricamente nuestro mercado natural sea la región. Es lógico que Uruguay haya decidido acoplarse a las dos principales economías del Cono Sur, pero no ha sido un proceso lo suficientemente fluido como debía y se esperaba que fuese. A partir de la creación del Mercosur, una tendencia innegable ha sido el constreñimiento del bloque para con nuestra inserción extrarregional. 


\section{Capítulo 3. Política comercial externa del Uruguay}

"No existe la prosperidad garantizada. Nada es para siempre. El futuro no es una proyección del pasado. El hecho de que nos haya ido bien en el pasado no nos garantiza ni tampoco nos da el "derecho" de que nos vaya bien en el futuro."

Enrique Baliño, "No más pálidas"

Si tomamos como punto de partida el desarrollo histórico previamente descrito, y la relevancia que ha tenido, y se le ha asignado al comercio internacional en el imaginario colectivo de nuestro país, parece paradójico el estado de situación actual en material de acuerdos internacionales firmados por Uruguay, así como el rezago existente respecto a sus principales competidores en los principales destinos complementarios a nuestra producción.

Como señalamos en el marco teórico, la política comercial involucra a la estrategia y la generación de los mecanismos necesarios para poder impulsar procesos de integración económica-comercial de un país, proponiéndose generar flujos de comercio e inversión entre ese país con el resto de la comunidad internacional. Uno de los objetivos a perseguir es la negociación de acuerdos con terceros que eliminen barreras arancelarias de acceso a mercados, estimulen la inversión y contribuyan a la reasignación de recursos hacia actividades más productivas que agreguen valor. En ese sentido, tanto la cantidad como la calidad y relevancia de los acuerdos negociados no parecen estar a la altura de las necesidades actuales de nuestro país. A esto debe sumársele el estado de situación actual de nuestra principal plataforma de inserción extracontinental, el Mercosur.

Mientras que el siglo XXI ha traído consigo alteraciones significativas en materia de nuestros principales destinos de exportación, así como en cuanto a nuestra oferta exportable, no ha habido los avances correspondientes en cuanto a acuerdos negociados si se toma en cuenta el crecimiento exponencial que han tenido los tratados de libre comercio mundialmente. Al 20 de mayo del 2021 han sido notificados en la OMC 349 acuerdos comerciales regionales (OMC, 2020), una cifra contundente si consideramos que a principios de este siglo estaban vigentes menos de 100 acuerdos. Las uniones aduaneras son una ínfima parte de estos 349 acuerdos. Hoy en día, existen solamente 18 acuerdos notificados como unión aduanera, siendo la Unión Europea el ejemplo más exitoso (Borchert \& Magntorn, 2018). Todo pareciera indicar que el Mercosur -y por tanto Uruguay- caminan en una dirección que no es a la cual se dirige el resto del mundo.

Es un hecho que Uruguay ha obtenido avances en la diversificación y la calidad de su matriz productiva. Pero también es un hecho que esa diversificación no ha sido acompañada de ventajas competitivas en materia de acceso a mercados. Según datos de Trademap, en relación con la diversificación, en el año 2001 Uruguay exportaba a 122 destinos, mientras que en 2019 exportó a 164 destinos. Esto significó un aumento del $34.43 \%$ en términos absolutos y de un $1.74 \%$ de crecimiento anual en número de socios comerciales (Trade Map, 2021). 
Este capítulo pretende formular una descripción del contenido y las principales características de la política de inserción económica-comercial del Uruguay, señalando los acuerdos vigentes en materia de bienes, servicios, e inversiones, así como ahondando en las condiciones de acceso a nuestros principales mercados de exportación.

\subsection{Evolución reciente del comercio exterior}

Haciendo una breve recapitulación de la evolución reciente de nuestro comercio exterior, el 2020 significó la interrupción de 17 años consecutivos de crecimiento económico para nuestro país. Durante este período, el sector agroexportador y la inversión extranjera directa jugaron un rol fundamental, generándose transformaciones significativas a nivel de nuestra matriz productiva y oferta exportable.

Sostenida por un clima regulatorio estable y políticas de Estado iniciadas en las dos últimas décadas del siglo $\mathrm{XX}$, la economía uruguaya vio tasas de crecimiento sin precedentes. Algunas de las transformaciones observadas fueron la diversificación de la oferta exportable, con la aparición de la intensificación del cultivo de soja y la celulosa, y la diversificación de destinos de exportación como ya se ha mencionado. Tanto el alza en los precios de los commodities, como la llegada de inversión extranjera directa a la región, fueron elementos coyunturales que permitieron un crecimiento anual promedio del 3,89\% (Banco Mundial, 2021).

En esta línea, parte de los 30 años que cumplió el Mercosur el 26 de marzo de 2021, se dieron en este marco de transformaciones a nivel de la inserción económica-comercial de nuestro país. La estructura de nuestra matriz exportadora, nuestros principales destinos y productos de exportación, e incluso la relevancia del bloque como socio comercial han visto modificaciones, en algunos casos, significativas.

Tomaremos como puntos de referencia los años 1991, 2001, 2011 y 2019, es decir, el año de creación del Mercosur, y después lapsos de diez años con excepción del 2019 al tratarse del último año prepandemia, para realizar un breve recorrido por la evolución de nuestro comercio exterior a nivel de matriz exportadora, socios comerciales, y oferta exportable

\subsubsection{Oferta exportable}

Acorde a datos de la OMC (2021), a nivel de nuestra oferta exportable en materia de bienes, la economía uruguaya ha atravesado un proceso de concentración de su matriz exportadora. Tomando 1991 como punto de partida, en dicho año las exportaciones de nuestro país eran un 59\% agrícolas, $40 \%$ manufacturas, y $1 \%$ combustibles y minerales; analizando el 2019, la incidencia de las exportaciones agrícolas llega al $80 \%$, con manufacturas en un $18 \%$, y $2 \%$ combustibles y minerales.

Nuestro ingreso al Mercosur afectó de manera importante ciertas industrias de larga trayectoria en nuestro país como la textil y vestimenta que pasaron de USD 247 millones en exportaciones en 1991 a USD 36 millones 2019 (OMC, 2021). Asimismo, con el alza en los precios de los commodities, a nivel de incentivos, las inversiones también fueron redirigidas hacia el sector agroexportador donde existían mayores utilidades. A este aspecto coyuntural, debe sumársele la creciente competencia de manufacturas chinas 
que afectaron la industria nacional. Por otra parte, cabe destacar el crecimiento que tuvo el sector farmacéutico, químico y de autopartes, casi inexistentes al momento de la creación del Mercosur.

Mucho se discute acerca de si esto implica una primarización de nuestra oferta exportable. En términos industriales, puede decirse que sí; nuestros principales productos de exportación poseen menor contenido industrial que hace 30 años, sin embargo, si tomamos en cuenta su contenido tecnológico, esto ha crecido considerablemente (Labraga, 2014, p.4). Tanto la producción ganadera como agrícola, inversión extranjera y políticas gubernamentales mediante, vieron incrementado su contenido de innovación y desarrollo, sea a nivel de la genética utilizada, maquinaria o técnicas implementadas. Para nuestro país esto no es un fenómeno aislado, ya que las principales innovaciones técnicas siempre se han derivado a partir de nuestra apertura al mundo, tómese por ejemplo la revolución del lanar de la segunda mitad del siglo XIX. Hasta el 2001, la lana continuaba siendo uno de nuestros principales tres productos de exportación.

Tabla I - Ranking de los tres principales productos de exportación I99|-2019

\begin{tabular}{|c|c|c|c|}
\hline 199I & 2001 & 2011 & 2019 \\
\hline Lana & Carne bovina & Carne bovina & Carne bovina \\
\hline Carne bovina & Cueros & Soja & Celulosa \\
\hline Arroz & Lana & Arroz & Soja \\
\hline
\end{tabular}

Fuente: CEPAL/Uruguay XXI

Respecto a este último punto, en los últimos 30 años nuestros principales productos de exportación también han tenido cierta transformación; mientras que la carne bovina se ha mantenido siempre dentro de los tres principales productos exportados, los restantes dos integrantes de este podio han variado. La celulosa y soja suelen estar presentes, pero dependiendo de fenómenos climatológicos o de precios internacionales, el arroz y los lácteos pueden llegar a tener presencia. Lo que sí es claro es que productos de exportación históricos como lanas y cueros han quedado relegados en el ranking. De acuerdo al Informe de Comercio Exterior realizado por Uruguay XXI, a 2019, la lana ocupaba el decimosegundo lugar con el 2\% (USD $186 \mathrm{M}$ ) del total exportado y los cueros el decimocuarto lugar (USD 155 M) con el 2\% (Uruguay XXI, 2019, p.4).

Mención especial merece la exportación de servicios, y en particular, la de servicios no tradicionales. De acuerdo con el Informe de Servicios Globales de Uruguay XXI (2020):

...si bien las exportaciones de servicios son la tercera parte del total exportado (bienes y servicios), hubo un cambio radical en los tipos de servicios exportados (...), el turismo pasó de representar el 54\% de las exportaciones de servicios en 2001 a ser el 33\% en 2019. (...) por su parte, los servicios no tradicionales en 2001 eran menos de $20 \%$ y en 2019 representan el 35\% de las exportaciones de servicios (p.10).

Sumando las actividades de intermediación comercial, estas "juntas explican casi el 60\% de las exportaciones totales de servicios del país" (Uruguay XXI, 2020, p.10). 


\subsubsection{Socios comerciales}

Tomando el 2019 como referencia, último año prepandemia, el Informe de Comercio Exterior de Uruguay XXI, señala que las exportaciones uruguayas de bienes, incluyendo desde zonas francas, ascendieron a 9.230 millones de dólares. A nivel de socios comerciales, China aglomeró el 31\% de las exportaciones, seguido por la Unión Europea con el 17\%, y Brasil con el 13\% del total (Uruguay XXI, 2019, p.4). Más allá de haberse convertido, a partir del 2013, en nuestro principal socio comercial en términos de valores exportados, China también suele ser el principal destino de exportación respecto a nuestros principales productos de exportación como la carne bovina, soja y celulosa.

\begin{tabular}{|c|c|c|c|}
\hline \multicolumn{4}{|c|}{ Tabla 2 - Evolución de socios comerciales (Exportaciones) } \\
\hline I99|149 & 2001 & 201 I & 2019 \\
\hline Brasil (24\%) & Brasil (2I\%) & Brasil (20\%) & China (31\%) \\
\hline U.E. (24\%) & U.E. (19\%) & U.E. (20\%) & U.E. (I7\%) \\
\hline Argentina (II\%) & Argentina (6\%) & China (8\%) & Brasil (13\%) \\
\hline
\end{tabular}

Fuente: Mordechi, Piaggio / Uruguay XXI

La Unión Europea por su parte, en todos los años de referencia, siempre se ha encontrado entre los primeros tres destinos de exportación, siendo una tendencia inamovible; sin embargo, donde sí ha habido alteraciones es respecto a la incidencia del Mercosur y los países miembro, tanto a nivel de exportaciones como de importaciones.

\begin{tabular}{|c|c|c|c|c|}
\hline \multicolumn{5}{|c|}{ Tabla 3 - Evolución incidencia Mercosur } \\
sobre Exportaciones e Importaciones nacionales \\
\hline & 1991 & 2001 & 2011 & 2019 \\
\hline Exportaciones & $36 \%{ }^{150}$ & $41 \%$ & $29 \%$ & $19 \%$ \\
\hline Importaciones & $42 \%{ }^{151}$ & $47 \%$ & $41 \%$ & $37 \%$ \\
\hline
\end{tabular}

Fuente: OMC / Masi; Bittencourt / Uruguay XXI

Desde su creación hasta el año 2001, hubo un crecimiento en el intercambio comercial con el bloque; se crece de un $36 \%$ a un $41 \%$ en exportaciones, y del $42 \%$ al $47 \%$ en cuanto a importaciones. Sin embargo, teniendo como disparadores las crisis económicas de la región a finales de los noventa y a principios de los 2000, y con ellas, el estancamiento del bloque a nivel comercial, para nuestro país la incidencia del bloque ha disminuido significativamente a nivel de exportaciones. Del 2001 al 2019 las exportaciones hacia el Mercosur disminuyeron en un $22 \%$ y respecto a importaciones en un $5 \%$.

Algunos de los determinantes por parte de esta disminución son el surgimiento de China como principal socio comercial; la desindustrialización de nuestra oferta exportable que previamente tenía a Argentina como destino de exportación; y el surgimiento de barreras no arancelarias en el mercado argentino (y en alguna oportunidad más limitada en Brasil). Se menciona doblemente a Argentina porque es el país cuya incidencia más ha caído; mientras que en el 2001 representaba el 15\% del total de exportaciones, en el 2019 había caído al 4,8\%. 
A nivel del Mercosur como proveedor, el porcentaje de participación de Brasil ha sido relativamente estable en el período 2001-2019, con un promedio del $19,69 \%$ siempre contando con aproximadamente $20 \%$ del mercado uruguayo; Argentina ha contado con el $18,6 \%$ del mercado en el mismo período, pero sin la estabilidad de Brasil. Contando con períodos de elevada relevancia, pero decayendo en más del 10\% de 2001 a 2019 (Uruguay XXI, 2021).

Las consideraciones anteriores fueron realizadas a nivel de bienes, si tomamos en cuenta los servicios, a nivel de servicios tradicionales (turismo y transporte), el Mercosur recobra relevancia. A cifras del 2019, los países miembros del bloque representaban el $71 \%$ del total de turismo receptivo (Ministerio de Turismo, 2019, p.7), la principal actividad económica generadora de divisas de nuestro país (Uruguay XXI, 2017, p3). Por su parte, en términos de turismo emisivo, en el mismo año el bloque aglomeró el $87,9 \%$ del total (Ministerio de Turismo, 2019). En ambos casos Argentina es el principal socio comercial de nuestro país.

El año 2020, estuvo fuertemente marcado por la crisis sanitaria del Covid-19. Eso repercutió en el comercio internacional del Uruguay (por eso, optamos por presentar como último año 2019). Sin embargo, en cuanto a los destinos de exportación, no existieron muchas modificaciones. Si bien China continuó ocupando el primer lugar, con el 27\% de las exportaciones de bienes, Brasil ocupó el segundo lugar (15\%) y la Unión Europea pasó al tercer lugar con el 14\% (Uruguay XXI, 2021, p.6).

Donde tampoco se produjo variación fue en el podio de los tres principales productos exportados: carne bovina (20\%), celulosa $(14 \%)$ y soja $(9 \%)$. Ninguno de estos tres productos, ocupan el podio de los productos exportados al Brasil y, sin embargo, si son los tres principales productos exportados a China (Uruguay XXI, 2020, p.4).

\subsubsection{Condiciones de acceso de los principales bienes exportados por Uruguay}

Es un hecho que desde la firma del GATT en 1947 ha existido una reducción significativa de aranceles, así como la arancelización de medidas no arancelarias a derechos de aduana. Sin embargo, para países con una matriz exportadora netamente agroindustrial, los aranceles continúan siendo un obstáculo importante, y hasta prohibitivo, a nivel de acceso a mercados.

Uruguay cuenta con un acceso preferencial a países de América Latina, pero en términos de mercados que ofrecen mejores precios para productos tales como la carne, lácteos, cítricos, o arroz, los aranceles y cuotas continúan obstaculizando nuestra inserción comercial internacional. En 2019, último año previo a la pandemia Covid-19, según cálculos de la Asesoría de Política Comercial del Ministerio de Economía y Finanzas, Uruguay tuvo que pagar aproximadamente USD 337 millones en aranceles (Uruguay XXI, 2020, p.5).

Estos USD 337 millones se distribuyeron en un $80 \%$ entre China, Estados Unidos y la Unión Europea, donde China aglomero un 55\%, la Unión Europea un 18\% y Estados Unidos un lejano $7 \%$. En total, el arancel promedio pago fue del $4 \%$ ad valorem, con máximos de $27 \%$ para el caso del mercado japonés, y mínimos del $1 \%$. Más allá de que se haya abierto el mercado de la carne para Japón, los aranceles pagos son una 
clara demostración que, entre apertura de mercado y acceso a mercado en condiciones preferenciales, hay una brecha importante.

Si todos los competidores de Uruguay pagaran los mismos aranceles, este asunto no tendría relevancia, pero cuando se entra en detalle de las condiciones de acceso con las que cuentan países como Nueva Zelanda o Australia, es que verdaderamente se puede visualizar las condiciones competitivas desfavorables de nuestro país en algunos productos. Para el caso de la carne bovina y el mercado chino, Uruguay no cuenta con preferencias arancelarias mientras que la carne neozelandesa entra con $0 \%$ arancel y la australiana con un $4,8 \%$ comparado con el $12 \%$ uruguayo.

\subsection{Mercosur: estado de situación y desafios}

Hablar de la política comercial del Uruguay en materia de bienes es hablar del Mercosur y el entramado de acuerdos negociados tanto a nivel regional como por fuera del mismo. El Mercosur constituye un ejercicio permanente de negociación, pero por lo general estas negociaciones suelen darse entre miembros y no con terceros. Cuestiones tales como habilitaciones fitosanitarias, licencias de importación, y obstáculos técnicos al comercio son temas que a 30 años de la creación del bloque deberían estar saldados, pero no es así. Para una economía pequeña como la nuestra cualquiera de barreras puede afectar de manera importante a la industria nacional.

Salvo excepciones, la mayor parte de las preferencias arancelarias de las que goza nuestro país son producto de negociaciones llevadas adelante vía el Mercosur; de los 17 acuerdos firmados por Uruguay, solamente cinco fueron negociados de manera independiente por fuera del Mercosur. La naturaleza de unión aduanera del bloque así lo exige; habiendo una cesión de autonomía a nivel de política comercial de los países, en pos de lograr una mejor inserción, se negocia como bloque. Muchos se refieren a la Dec. 32/00, pero eso está plasmado en el propio Tratado de Asunción.

El Mercosur, hoy por hoy, se trata de un bloque que carece de un diálogo fluido entre sus principales economías, donde barreras no arancelarias para el comercio intrazona han aumentado, y en el que rige un Arancel Externo Común perforado, además de proteccionista. Asimismo, sigue encontrándose por fuera del acuerdo el principal intercambio comercial entre sus socios (vehículos y autopartes), y se observa una clara falta de continuidad en términos de negociaciones extrarregionalas (Bartesaghi, 2020).

La velocidad de la integración de los años `90, tan loada internacionalmente, se quedó en esa década, dando lugar a un siglo XXI en el que hubo un crecimiento institucional en todas las dimensiones salvo la comercial. Se concretaron acuerdos comerciales superficiales sin verdaderas implicancias económicas, y hubo un deterioro constante de su viabilidad como plataforma de Uruguay hacia una mejor inserción a mercados globales.

Es palpable como la consecución de los objetivos del Tratado de Asunción y posteriores protocolos quedaron íntimamente ligados a la voluntad política de los países miembro, en particular de Argentina y Brasil, quienes en pocas ocasiones pudieron, o quisieron, alejarse de sus trayectorias proteccionistas de larga data. Esto se dio de esta manera dada la naturaleza intergubernamental del bloque; al no existir un órgano supranacional, autónomo de intereses particulares de los Estados miembro, la velocidad de la integración quedó rehén a la voluntad de sus socios, y mucho más si consideramos la necesidad de 
consensos para la toma de decisiones. La reactivación de la agenda externa del Mercosur ha sido, y sigue siendo, una de las principales exigencias por nuestro país; reclamo que, de algún modo, fue mitigado con los avances obtenidos durante la confluencia de las presidencias de Mauricio Macri en Argentina y Jair Bolsonaro en Brasil.

A nivel de comercio intrazona, desde el 2018 en adelante se puede observar un retroceso generalizado de flujos comerciales, liderado por menores exportaciones e importaciones argentinas y brasileñas. Esta disminución del comercio ha sido de tal manera que para el 2019 las exportaciones hacia el bloque representaban el 11\% de las exportaciones totales del bloque, cifra más baja desde la crisis regional de 2001 y 2002. Para el caso de nuestro país, las exportaciones hacia el bloque disminuyeron en línea con las tendencias de los demás países; Brasil, como ya señalamos, continúa siendo nuestro principal destino de exportación en el bloque seguido por una distante Argentina (BID, 2020).

Observando los sucesos de los últimos cinco años, se puede observar que el Mercosur culminó negociaciones con la Unión Europea y con la Asociación Europea de Libre Comercio el mismo año (al 31 de octubre los mismos siguen sin ser firmados), generando las condiciones necesarias para estrechar una alianza intercontinental con enormes repercusiones para el comercio, el empleo y el crecimiento económico. De igual manera, se comenzaron negociaciones con Canadá, Singapur, Líbano y Corea del Sur, así como conversaciones exploratorias con Vietnam e Indonesia. Paralelamente, también se busca profundizar los acuerdos vigentes con Israel, India y la Alianza del Pacifico (MRREE, 2020). Lo que claramente evidencia el rol fundamental que cumple la voluntad política en la política comercial externa de un país.

Sin embargo, el cambio de signo político a nivel del gobierno argentino en 2019, a los pocos meses de haber asumido, ya generó corto circuitos a nivel de negociaciones extrazona, amagando la cancillería argentina a salir de las negociaciones con terceros, para posteriormente aclarar su postura y suspender las negociaciones en curso, pero permanecer en los acuerdos ya cerrados: Unión Europea (UE) y Asociación Europea de Libre Comercio (EFTA).

En este panorama de alta incertidumbre a nivel de negociaciones internacionales, acrecentado por la pandemia Covid-19 que ha confirmado una línea que se venía desarrollando de mayor proteccionismo a nivel de política exterior de los principales mercados del mundo, Uruguay debe hacer énfasis en mejorar el funcionamiento de la zona de libre comercio intrazona; abordando las crecientes medidas no arancelarias existentes. Una modernización del funcionamiento del bloque es lo que más le favorecería a nuestro país, considerando la posibilidad de negociaciones bilaterales con terceros, o por lo menos a distintas velocidades, pero sin la interrupción de estas (Palumbo, 2020). La única posibilidad de crecimiento que tiene el país es logrando colocar sus productos en el exterior al mejor precio y menor costo posible.

Respecto a esto último, en el marco de la cumbre de presidentes conmemorando los 30 años desde la firma del Tratado de Asunción que se llevó adelante en marzo 2021, la posición uruguaya, comunicada por el Presidente Lacalle $\mathrm{Pou}^{4}$, se centró en torno a la necesidad por un mayor grado de pragmatismo en el bloque, haciendo énfasis en "profundizar la zona de libre comercio y rever el arancel externo común" así como "insistió en 
avanzar en la flexibilización del Mercosur o apelar a distintas velocidades". Lacalle Pou afirmó que "...no hay tiempo para grandes diálogos o grandes comisiones, hay que actuar."

A fines de abril 2021, las palabras del presidente Lacalle Pou se vieron plasmadas en la propuesta presentada por Uruguay, con respaldo de Brasil, ante el Consejo del Mercado Común, abordando la necesidad por establecer un plan de negociaciones externas, evaluar la posibilidad de ofertas individuales, plazos diferenciales, o ritmos de negociación diferentes al momento de abordar negociaciones del bloque, y, por último, flexibilizar el arancel externo común. Luego de haber presentado y defendido esta investigación, el Presidente de la República, Dr. Luis Lacalle Pou, anunció en conferencia de prensa ${ }^{5}$ haber recibido un planteo formal por parte de la República Popular China para iniciar un estudio de prefactibilidad como un paso previo al análisis y negociación de un tratado de libre comercio. Esta noticia, a nuestro juicio, viene a reforzar la idea de la necesaria modernización y adaptación de la estructura institucional para poder enfrentar los nuevos desafíos y nuevas oportunidades que se le pueden presentar al Uruguay, al adoptar una estrategia de inserción internacional con carácter más aperturista y flexible.

\subsection{Inserción comercial por fuera del Mercosur: TLC con México y Chile, y el Sistema Generalizado de Preferencias}

El Tratado de Libre Comercio firmado entre Uruguay y México en el año 2003, vigente desde el 2004 y ampliado en repetidas ocasiones, fue el primer acuerdo de nueva generación negociado por nuestro país. Fue registrado como Acuerdo de Complementación Económica en el marco de la Asociación Latinoamericana de Integración (ALADI) y su negociación fue producto de una autorización expresa por parte de los demás miembros del Mercosur (sin la cual no podría haberse realizado). Es el único tratado de este tipo que Uruguay tiene por fuera del bloque (Labraga, 2014, p.2).

A 16 años del acuerdo, se puede observar que no se ha tratado de un acuerdo que ha revolucionado la política comercial de nuestro país. Más allá de tratarse de un TLC, el amplio número de excepciones destinadas a proteger los mercados internos de ambos socios no permitieron una creación o desviación de comercio significativa (Rosselli, 2017). A pesar de que hoy por hoy México sea nuestro sexto socio comercial en materia de exportaciones (Uruguay XXI, 2019, p. 5), misma posición que en el 2004, poco puede atribuirse este hecho al acuerdo. Sin embargo, más allá de no haber generado un intercambio comercial trascendental para nuestro país, significó un antes y un después en términos de validación de la capacidad negociadora de nuestro país y una confirmación del constante deseo de Uruguay de mirar más allá del barrio. Se trató del primer acuerdo negociado con estas características, y a su vez, con un interlocutor comercial que ha demostrado una amplia trayectoria a nivel de negociaciones de acuerdos de libre comercio. Permitió establecer un antecedente respecto a la negociación por parte de Uruguay de este tipo de acuerdos.

Por su parte, el TLC (Tratado de Libre Comercio) firmado con Chile en 2016 se trata de una ampliación del Acuerdo de Complementación Económica vigente entre el Mercosur

5 Uruguay Presidencia (2021) Uruguay recibió planteo formal de China para avanzar en la firma de un tratado de libre comercio. Visto en: https://www.gub.uy/presidencia/comunicacion/noticias/uruguay-recibio-planteo-formal-china-para-avanzar-firmatratado-libre $(03 / 10 / 2021)$ 
y Chile desde el año 1996. El acuerdo firmado significa la incorporación de nuevas disciplinas al relacionamiento comercial Uruguay-Chile tales como comercio electrónico, medio ambiente, género y comercio, legislación laboral, y propiedad intelectual. Hoy por hoy, se encuentra liberalizado en un $100 \%$ el comercio de bienes, existiendo de igual forma un acuerdo bilateral de protección y promoción de inversiones con Chile y un tratado de doble tributación. El valor diferencial del acuerdo pasa por profundizar el relacionamiento bilateral mediante las nuevas dimensiones incorporadas al acuerdo. Al igual que el TLC con México en su momento, la negociación del acuerdo significa otro hito para la diplomacia uruguaya al acordar disciplinas de última generación.

Por fuera de los acuerdos negociados por nuestro país, Uruguay también es beneficiario del Sistema Generalizado de Preferencias con el que obtiene condiciones de acceso preferenciales unilaterales a los mercados de Australia, Nueva Zelandia, Noruega, Suiza, y la Unión Económica Euroasiática (Federación Rusa, Bielorrusia, Kazajstán, Armenia, y Republica Kirguisa). Debe destacarse que, con anterioridad, Uruguay era beneficiario de preferencias unilaterales concedidas por Canadá, Estados Unidos, Japón, Turquía, y la Unión Europea, pero por motivos del crecimiento económico que nuestro país tuvo en las últimas dos décadas, ha perdido acceso a las mismas al considerarse un país de ingresos medios-altos. Al estar limitados, como ya hemos mencionado, en términos de negociación de preferencias arancelarias, la intención de Uruguay es de negociar el reingreso al Sistema Generalizado de Preferencias respecto a las condiciones favorables de las que gozábamos previamente con varios países desarrollados. Al respecto, el Dr. Marcel Vaillant (2021) opinó:

Uruguay debería dejar de insistir en el Sistema Generalizado de Preferencias como estrategia de inserción internacional. Es un instrumento del siglo XX. En cierta medida, nos van a renunciar los otros, dado que dejamos de calificar. Ningún país tiene una corriente de comercio exitosa y dinámica con un mecanismo no recíproco de preferencias arancelarias. 


\section{Capítulo 4. Los desafios de la institucionalidad en la política comercial externa del Uruguay}

"Un gran desafío une al equipo. Más aún, lo fusiona, porque lo convierte en algo que está más allá de los Individuos"

Gonzalo Noya, Algo + Grande

La institucionalidad por detrás de la formulación e implementación de la Política Comercial Externa de nuestro país no elude características generales atribuibles a otras esferas de la administración pública. Involucra actores principales y secundarios, estatales y no estatales, distintos poderes del Estado, así como instancias de articulación y coordinación interinstitucional.

Asimismo, y al igual que cualquier otra política pública, la misma debe enmarcarse en una visión estratégica de desarrollo económico sustentable a largo plazo, encontrándose entrelazada junto a una multitud de otras políticas gubernamentales. Además, una estructura institucional del siglo XXI debe tener la capacidad de ser dinámica, flexible y proactiva; capaz de generar información de calidad para tomar decisiones acertadas que permitan colocar nuestra oferta exportable de manera competitiva.

Antes de ingresar directamente al diseño institucional de la política comercial externa del Uruguay, cuando conversamos con los distintos actores a los que entrevistamos para esta investigación y los consultábamos acerca de las fortalezas de la institucionalidad del Uruguay, no dudaban en resaltar la solvencia de las instituciones, la calidad en cuanto a certidumbre y estabilidad de las reglas, la reputación sólida, tanto en términos diplomáticos como técnicos, la larga tradición de respeto por la ley y los compromisos asumidos, la seriedad de nuestra institucionalidad pública y la responsabilidad del sector privado. Efectivamente, nuestro apego a las normas, el respeto al derecho internacional, la confiabilidad jurídica, son activos a destacar a la hora de hablar de nuestra institucionalidad.

Como hemos ya mencionado, nuestro objetivo de investigación es el diseño institucional de la PCE. La formulación e implementación de esta es un proceso mediante el cual se toman decisiones y se efectúan acciones que involucran valores, prioridades e intereses que compiten entre sí (Cohen, Blecker \& Whitney, 2003). Bouzas (2020) ha señalado:

El formato institucional y los procedimientos a través de los cuales transcurre ese proceso influyen sobre la forma en que esos conflictos se gestionan y administran. Las intervenciones públicas en el campo de la PCE no deben ser vistas como un conjunto de acciones con resultados previsibles, sino como una colección de iniciativas cuyos resultados son afectados por las características del proceso a través del cual ellas se formulan e implementan (p.3).

Por institucionalidad entendemos a los arreglos y estructuras generadas en pos del abordaje de la problemática presentada por la inserción económica-comercial de nuestro país. Atañe a los actores involucrados y a cómo estos interactúan entre sí para formular una política comercial en línea con los intereses nacionales.

Corresponde mencionar que la institucionalidad de la política comercial externa, y su correcto funcionamiento, es un desafío al que se enfrentan todos los países del mundo, 
independientemente de su grado de desarrollo. Sin embargo, en base a la literatura existente, podemos señalar que no existen modelos institucionales superiores. De ahí la importancia para que cada país busque y construya aquello que mejor se adapte a su realidad y los desafíos que tiene por delante. La indefinición conceptual de la política comercial, ubicándose en un punto medio entre la política económica y la política exterior, pero también siendo influenciada por una plétora de otras políticas (por ejemplo, ambiental e industrial), genera que su abordaje no sea un fenómeno sencillo, y, por lo tanto, es frecuente, sobre todo en países que no tienen una institucionalidad estable, que existan pujas por su liderazgo.

Julieta Zelicovich (2020), en su trabajo `Anatomía de la Instituciones de la política comercial externa. Estudios de casos', destaca al menos cuatro fuentes de tensión en materia de PCE y los diseños institucionales:

a. La disputa entre las lógicas económicas y políticas a la hora de definir una política;

b. La falta de consensos en lo que es "la política comercia óptima";

c. La relación entre el comercio y otros aspectos de la economía;

d. La difusión de la autoridad según los distintos marcos normativos y procesos decisorios (Cohen, Blecker \& Whitney, 2003)

Uruguay es una república democrática, regida por un sistema presidencialista de gobierno. Está dividido en tres poderes independientes: Ejecutivo, Legislativo y Judicial.

La Constitución de la República vigente, aprobada en 1967, con algunas reformas posteriores -la última en 2004-, le confiere potestades específicas al Poder Ejecutivo y Poder Legislativo en materia de PCE. A nivel de Poder Ejecutivo, generalmente se ha señalado el artículo 168, numeral 20 de la Constitución, que refiere a la autoridad de "concluir y suscribir tratados, necesitando para ratificarlos la aprobación del Poder Legislativo." Sin embargo, a nuestro entender, porque hace al uso de los recursos humanos en materia institucional, creemos oportuno señalar también el numeral 12 del mismo artículo 168. Allí se expresa que, al Presidente de la República, ya sea actuando con el Ministro respectivo (en este caso el Ministro de Relaciones Exteriores) o con el Consejo de Ministros, le corresponde:

...nombrar el personal consular y diplomático, con obligación de solicitar el acuerdo de la Cámara de Senadores, o de la Comisión Permanente hallándose aquélla en receso, para los Jefes de Misión. Si la Cámara de Senadores o la Comisión Permanente no dictaran resolución dentro de los sesenta días el Poder Ejecutivo prescindirá de la venia solicitada.

Los cargos de Embajadores y Ministros del Servicio Exterior serán considerados de particular confianza del Poder Ejecutivo, salvo que la ley dictada con el voto conforme de la mayoría absoluta del total de componentes de cada Cámara disponga lo contrario.

Dentro del Poder Ejecutivo, a nivel de la inserción económica-comercial del Uruguay, la centralidad de la toma de decisiones gira en torno al eje Ministerio de Relaciones Exteriores-Ministerio de Economía y Finanzas. La interacción entre estas dos carteras determina la orientación de nuestra política comercial, generando la intervención de diferentes actores dependiendo de la idoneidad necesaria o los consensos políticos requeridos. La ejecución de la política comercial es un fenómeno tanto técnico, como político, siendo imposible su monopolio por parte de un solo actor. Sin embargo, como 
señalan Halle \& Wolf (2007), tanto el proceso como el contenido son importantes en el desarrollo de una política pública. Las instituciones nuclean preferencias; fortalecen a determinados actores a partir de darles acceso a la decisión; o bien, aíslan de tales presiones a los policymakers, dándoles mayor libertad de acción en el establecimiento de las políticas. Se trata de un proceso eminentemente político (Zelicovich, 2020, p.9) Ahora bien, como hemos señalado, para su ejecución, no puede quedarse allí y debe incorporar lo técnico.

En un plano secundario, pero igualmente relevante, se encuentran las divisiones de asuntos internacionales de otros ministerios como el de Ganadería, Agricultura y Pesca (MGAP), el de Industria, Energía y Minería (MIEM), el de Turismo (MINTUR), el recientemente creado de Ministerio de Ambiente (MA), y el de Salud Pública (MSP), que brindan su conocimiento técnico y experiencia al momento de abordar temáticas de su competencia. De la misma manera, en el ámbito estatal también se pueden encontrar organismos especializados tales como la Oficina de Planeamiento y Presupuesto (OPP), el Instituto Nacional de Carnes (INAC), el Instituto Nacional de la Leche (INALE), el Instituto Nacional de Vitivinicultura (INAVI), y Uruguay XXI.

Como organismo de articulación y coordinación interinstitucional se encuentra la Comisión Interministerial para Asuntos de Comercio Exterior, creada en el año 2006, cuya finalidad es servir de ámbito formulador y articulador entre los principales actores involucrados en la inserción económica-comercial de nuestro país. Siendo la CIACEX (Comisión Interministerial para Asuntos de Comercio Exterior) la principal instancia a nivel de ministros, la Sección Nacional se ubica como el principal escenario de articulación a nivel técnico.

Como último actor dentro del entramado público de sujetos participes en el armado y ejecución de la política comercial se encuentra al Poder Legislativo. Volviendo a la Constitución de la República, el artículo 85, señala que a la Asamblea General -Cámara de Senadores y Cámara de Representantes-, le compete:

decretar la guerra y aprobar o reprobar por mayoría absoluta de votos del total de componentes de cada cámara, los tratados de paz, alianza, comercio y los convenios o tratados de cualquier naturaleza que celebre el Poder Ejecutivo con potencias extranjeras (numeral 7).

Sin embargo, el Poder Legislativo tiene, además, según el numeral 3 de este mismo artículo 85, la posibilidad de expedir leyes relativas, entre otras cosas, al comercio exterior. Por tanto, es cierto que la mayoría de las veces se oye hacer referencia al rol de contralor de la política comercial con la posibilidad de veto que tiene el Poder Legislativo respecto a la aprobación o no de los acuerdos firmados por el Poder Ejecutivo, pero no menos cierto es que la Constitución le da el poder de iniciativa para formular leyes que pueden incidir en la política comercial externa. Para todo esto, tanto la Cámara de Senadores como la Cámara de Representantes cuentan con una Comisión de Asuntos Internacionales.

Por fuera de la esfera gubernamental, se encuentran actores no estatales relevantes y aglutinadores de distintos intereses sectoriales como la Unión de Exportadores del Uruguay (UEU), la Cámara de Industrias del Uruguay (CIU), la Cámara Nacional de Comercio y Servicios (CNCS), la Cámara Mercantil del Uruguay, la Cámara Uruguaya de Tecnologías de la Información (CUTI), la Asociación Rural del Uruguay (ARU), y el PIT-CNT. 
Ilustración 1 - Estructura de la institucionalidad de la política comercial externa del Uruguay en la actualidad (elaboración propia)
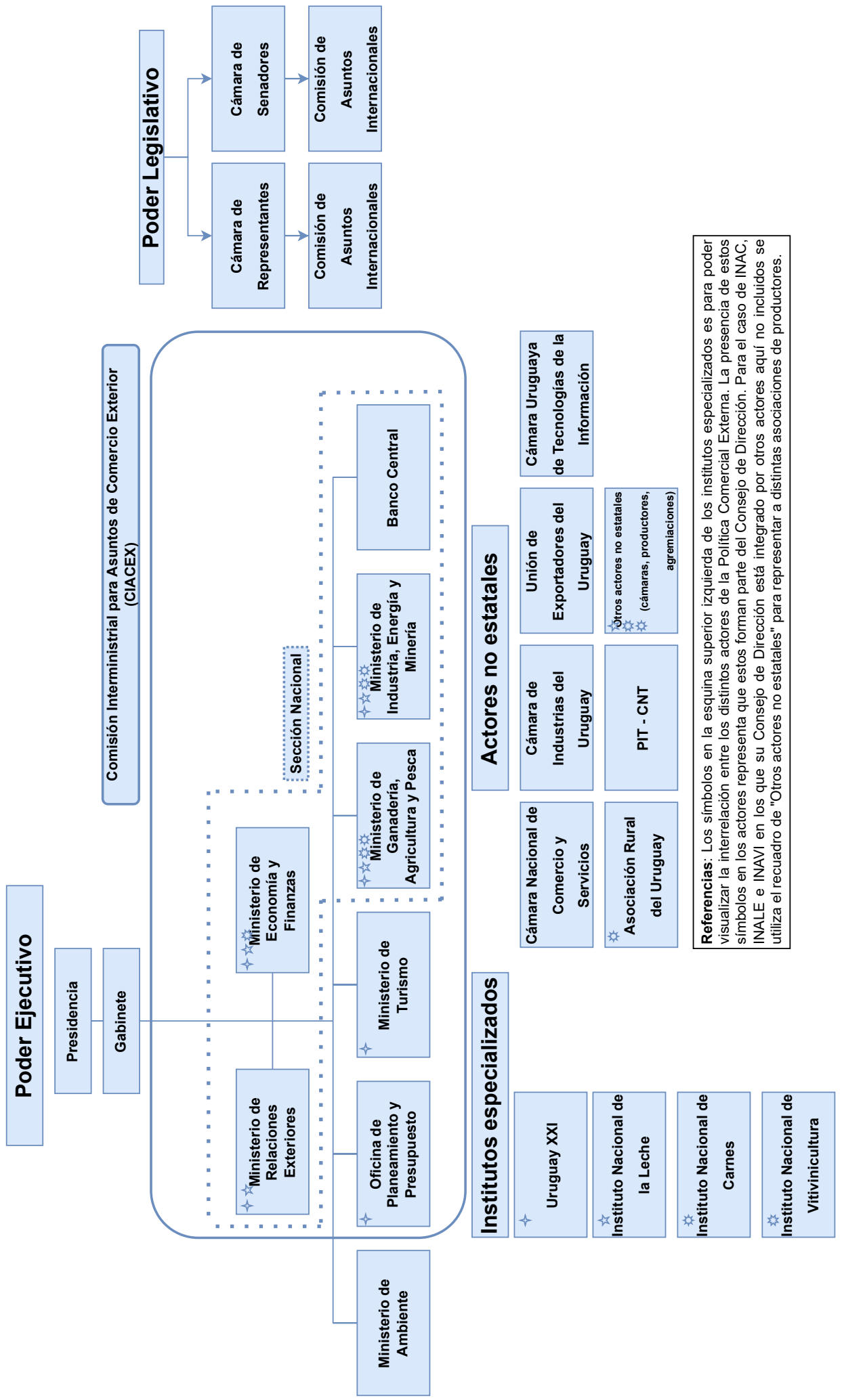
Dentro del marco jurídico vigente en Uruguay, no existe ninguna norma constitucional o legal que le asigne responsabilidad directa a ningún Ministerio para encargarse de la política comercial externa del país. Sin embargo, se puede afirmar que el liderazgo es de competencias modulares, compartido entre el Ministerio de Relaciones Exteriores y el Ministerio de Economía y Finanzas.

Creemos oportuno explicitar las competencias formales de estos dos principales organismos de la estructura institucional de la política comercial externa y su incidencia en la formulación de la misma. En el documento completo de la tesis, abordamos otros organismos estatales y no estatales que componen el complejo entramado de la arquitectura institucional vigente en el Uruguay.

\section{Ministerio de Relaciones Exteriores}

El Decreto 197/997, en su capítulo I señala que el MRREE “es el órgano políticoadministrativo del Estado encargado de planificar, dirigir, ejecutar y coordinar las relaciones del país con otros Estados y con los Organismos Internacionales, así como lo atinente a cuestiones internacionales en materias atribuidas a otros Ministerios." Las competencias están enfocadas a la política exterior de la República en toda materia. Y, específicamente referido a las negociaciones en el exterior, el decreto dice:

"Negociar, suscribir y ratificar tratados, convenciones, contratos y acuerdos entre la República y Estados o instituciones extranjeras o internacionales e intervenir en la negociación y suscripción de los celebrados por otros Organismos del Estado u Organismos Públicos Nacionales. Conducir las negociaciones comerciales internacionales en el marco de la política exterior."

Para llevar adelante sus cometidos, el MRREE, de acuerdo a la Constitución de la República -al igual que los demás Ministerios- se organiza en torno a un Ministro, un Subsecretario y una Dirección General de Secretaria, de la cual dependen las direcciones generales temáticas.

En la siguiente ilustración, presentamos la Estructura Organizativa del Ministerio de Relaciones Exteriores:

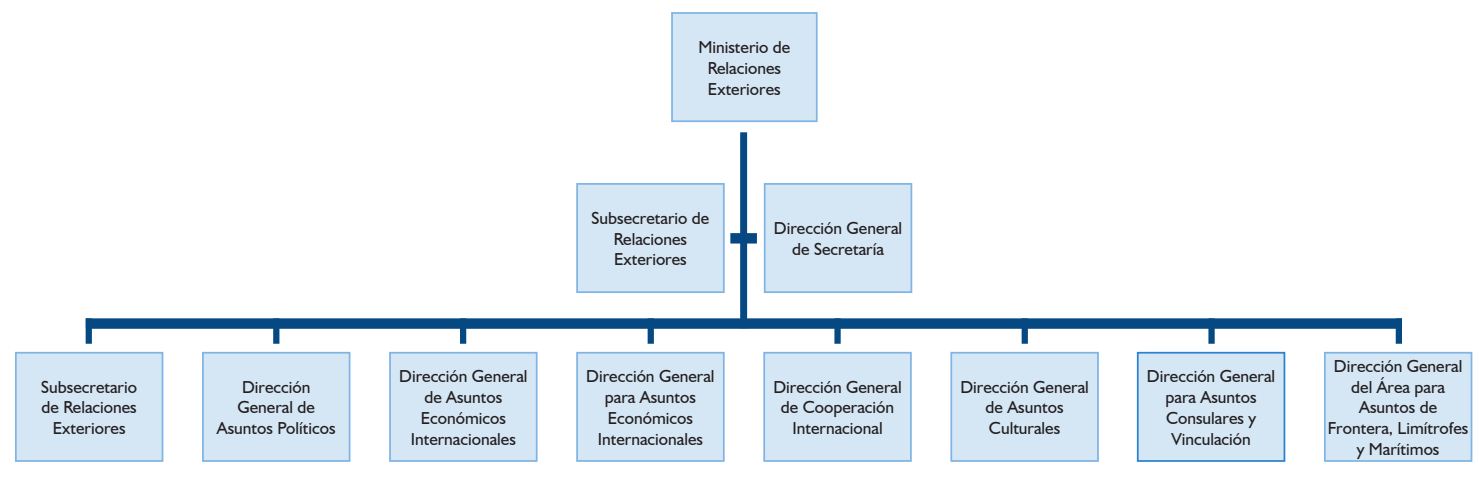


El Ministerio cuenta con un Gabinete Ministerial que, si bien no constituye una unidad organizativa, aparece como un espacio de coordinación a nivel de Cancillería. Lo convoca el Ministro y está integrado por el propio Ministro, el Sub-Secretario, el Jefe de Gabinete, los Directores Generales y el Director de Protocolo.

Por fuera de la estructura orgánica del Ministerio, es importante destacar el rol que cumplen las Misiones Diplomáticas y Oficinas Consulares en el exterior.

Del total de direcciones generales, dos tienen cometidos directos en relación a la política comercial externa: Dirección General para Asuntos Económicos Internacionales y Dirección General de Integración y Mercosur.

\section{Dirección General para Asuntos Económicos Internacionales}

A esta Dirección le corresponde:

Planificar y ejecutar en coordinación con los organismos nacionales competentes, las relaciones económicas internacionales a nivel bilateral y multilateral (a excepción de los cometidos específicamente asignados a la Dirección General para Asuntos de Integración y Mercosur, con la cual trabajará coordinadamente); intervenir en lo relacionado con la política del comercio internacional y su ejecución y obtener y brindar información y asistencia en esa materia a sectores públicos y privados interesados; formular las pautas de acción de los Agentes diplomáticos en sus funciones de carácter económico-comercial y el contralor de su ejecución; desarrollar la capacidad de análisis, iniciativa y formulación de propuestas para la conducción estratégica de la Cancillería en los temas de su competencia y dirigir las actividades vinculadas a la misma, coordinando esfuerzos con las demás Direcciones Generales (Artículo 88).

Para llevar adelante su funcionamiento, esta Dirección General se apoya en el trabajo de tres direcciones:

La Dirección de Asuntos Económicos Bilaterales tiene por atribuciones el estudio, seguimiento y preparación de documentos y asesoramiento en términos del relacionamiento económico bilateral con otros Estados a la Dirección General y ejecutar sus decisiones en los temas económicos vinculados con las relaciones internacionales del país. Prepara las instrucciones e información a las Misiones y Oficinas del Ministerio en dichas áreas. Participa en comisiones mixtas, misiones especiales y misiones ad-hoc y evalúa y realiza recomendaciones respecto a los planes de trabajo de las Misiones y Oficinas en el exterior, coordinando la posición del país con los demás órganos nacionales competentes en la materia.

La Dirección de Inteligencia y Promoción Comercial e Inversiones se encarga de la gestión de datos relativos a empresas extranjeras interesadas en la oferta exportable del Uruguay, la comunicación de dicha información al empresariado uruguayo así como demás instituciones interesadas, la organización de misiones empresariales al exterior y la elaboración de documentos informativos relativos a la inteligencia comercial, y la promoción de exportaciones e inversiones.

La Dirección de Organismos Internacionales Económicos tiene competencias en el análisis, la evaluación y el seguimiento de las actividades de los organismos 
internacionales de los que Uruguay forma parte o cuya actividad interese a éste en el área económico-comercial. Prepara documentos y asesora a la Dirección General y ejecuta sus decisiones en esta materia. Entiende todo lo relacionado con la organización y desarrollo de conferencias internacionales en las que intervenga la República o sean de interés para ésta. Debe informar e instruir a las misiones acreditadas ante dichos organismos.

\section{Dirección General para Asuntos de Integración y MERCOSUR}

A esta Dirección General le corresponde:

Estudiar, planificar y ejecutar la política nacional en todas las actividades tendientes a la consolidación y desarrollo del MERCOSUR, así como a sus relaciones externas en materia de integración; estudiar, planificar y ejecutar en lo pertinente las relaciones económicas dentro de los procesos de integración de ALADI y la Integración Hemisférica; informar e instruir a las Misiones y Oficinas del Ministerio en estas materias; coordinar su acción con las demás dependencias del Ministerio y con otros organismos del Estado; estudiar y hacer el seguimiento de todos los procesos de integración en diferentes partes del mundo; intervenir en todas las cuestiones atinentes a la integración en las zonas fronterizas; desarrollar la capacidad de análisis, iniciativa y formulación de propuestas para la conducción estratégica de la Cancillería en los temas de su competencia y dirigir las actividades vinculadas a la misma, coordinando esfuerzos con las demás Direcciones Generales (Artículo 94).

Esta Dirección General, se divide en dos direcciones:

La Dirección de Integración lleva adelante el estudio, seguimiento y asesoramiento de la Dirección en lo pertinente a las relaciones del Mercosur con otros procesos de integración a nivel regional, hemisférico y extrarregional, así como con otros Estados; informa e instruye a la Misiones acreditadas ante los países miembros de dichos procesos de integración; estudia, analiza y realiza el seguimiento de la actuación de la República en el marco de la ALADI. De la misma manera, realiza el seguimiento a sucesos relativos a procesos de integración y cooperación económica -formales e informales- que entren en los intereses estratégicos de nuestro país, así como las cuestiones referentes a la integración en las zonas fronterizas.

La Dirección Mercosur tiene por objeto el estudio, seguimiento y asesoramiento a la Dirección General en todo lo relativo al desarrollo y consolidación del Mercosur y su profundización. Prepara informes y recomendaciones en los temas de su competencia; informa e instruye a las Misiones acreditadas ante los países miembros. Esta dirección coordina el trabajo con los distintos órganos y espacios del Grupo Mercado Común (GMC) y la Comisión de Comercio del Mercosur (CCM).

\section{Ministerio de Economía y Finanzas}

El Ministerio de Economía y Finanzas tiene un rol fundamental como organismo encargado del rumbo general de la economía y las finanzas públicas. Participa también en la formulación e implementación de la política comercial externa. Tiene competencias específicas en materia de aduana, regímenes específicos de inversiones, doble tributación, 
tasas vinculadas al comercio exterior. En entrevista realizada al Ec. Hodara para esta investigación, nos señaló: “la política comercial externa es una faceta de la política económica. Tiene impacto sobre la asignación de recursos, sobre las políticas del desarrollo del país." (Hodara, 2021)

Dentro de los cometidos estratégicos, al MEF (Ministerio de Economía y Finanzas) le corresponde:

la conducción superior de la política nacional económica, financiera y comercial (...) Es rector de los sistemas de administración financiera, tributaria y aduanera y del sistema arancelario; coadyuva a potenciar la competitividad del país; promoviendo la inserción de sus productos y servicios en el exterior.

Existen dos asesorías que cumplen un papel importante en la formulación e implementación de la política comercial, dentro del MEF: la Asesoría de Política Comercial y la Asesoría Tributaria.

\section{Asesoría de Política Comercial}

La Asesoría de Política Comercial cumple un papel de asesoramiento, coordinación e intervención en las negociaciones comerciales vigentes de nuestro país; sus tareas son llevadas adelante en constante interacción con el MRREE. Dentro de sus principales cometidos, se encuentran: coordinación de las negociaciones del Mercosur (Mercado Común del Sur) competentes al MEF; asesorar en materia de política comercial y de negociaciones comerciales internacionales bilaterales, regionales y/o multilaterales; proponer las estrategias de negociaciones comerciales y participar en las mismas; intervenir en la ejecución de los Acuerdos y Convenios comerciales que celebre la República con otros países; administrar los regímenes de origen en los diferentes acuerdos preferenciales, incluyendo el Sistema Generalizado de Preferencias, entre otras.

La APC (Asesoría de Política Comercial) se compone de cuatro unidades operativas y dos unidades de información y evaluación. Las unidades cuatro unidades operativas son:

- Unidad de Administración de Instrumentos de Política Comercial: aplica y gestiona los distintos instrumentos de política comercial que utiliza nuestro país en el cumplimiento de obligaciones internacionales, la promoción de nuestra oferta exportable, y la defensa de la producción nacional.

- Unidad Negociaciones Comerciales: encargada de los preparativos y la puesta en práctica de negociaciones comerciales (bienes/servicios/inversiones).

- Unidad de Origen: gestión de regímenes de origen y certificado de origen digital.

- Unidad de Operaciones de Comercio Exterior: encargada de los regímenes aduaneros especiales y su incorporación a la Ventanilla Única de Comercio Exterior (VUCE). Es de su competencia la gestión del Sistema Generalizado de Preferencias.

- Unidad de Procesos del Comercio Exterior: responsable del uso e incorporación de herramientas digitales a los procedimientos de comercio exterior. También le compete los acuerdos de contratación pública. 
Por su parte, las unidades de asesoría y evaluación son:

- Unidad de Asesoramiento Jurídico en Política Comercial: responsable de la elaboración de la normativa jurídica (resoluciones ministeriales, decretos, leyes, etc.) que gobierna nuestra política comercial. También se encarga de la solución de controversias en el marco de acuerdos firmados.

- Unidad de Evaluación de Impacto: responsable de llevar adelante el análisis del potencial impacto de acuerdos comerciales negociados o en negociación. Estos suelen ser insumos para la discusión de la pertinencia de una negociación, así como para la ratificación de tratados en el parlamento.

\section{Asesoría Tributaria}

En el entramado de la política comercial, la Asesoría Tributaria parecería ser un organismo de poca relevancia, sin embargo, dada la estrategia respecto a la exportación de servicios no tradicionales y la atracción de inversiones llevada adelante por nuestro país en los últimos años, ha tenido un rol importante en la negociación de acuerdos de doble tributación y en acuerdos de protección de inversiones. Específicamente, la normativa le asigna:

"Colaborar con la autoridad competente en lo atinente al estudio y negociación de los convenios internacionales en materia tributaria, así como propender por su adecuada implantación y cumplimiento en coordinación con la División Grandes Contribuyentes."

\section{Dirección Nacional de Aduanas}

Al igual que en todo país del mundo, la verificación y control de la mercadería que ingresa y egresa del país es un asunto fundamental para que los flujos comerciales se realicen de manera ordenada, en cumplimiento de la normativa vigente nacional e internacional, y con el cobro de los aranceles/tasas correspondientes.

La Dirección Nacional de Aduanas depende del MEF, siendo el nombramiento de su Director competencia del Ministro de Economía y Finanzas. Las funciones de la DNA (Dirección Nacional de Aduanas) son estipuladas en el Código Aduanero (CAROU Ley 19.276). La DNA se trata de un actor fundamental al momento de la ejecución de la política comercial externa, en particular al momento de controlar las mercancías enviadas al exterior, y aquellas recibidas por nuestro país. Cumple un rol importante al momento de la implementación de normativa relativa a la facilitación de comercio, la elaboración de procedimientos de importación/exportación, la recolección de tributos aduaneros, la clasificación arancelaria de mercadería, la habilitación de áreas para operaciones aduaneras, y la elaboración de estadísticas a nivel del comercio exterior de bienes.

\section{Área Zonas Francas}

El Decreto N³09/018 es la más reciente reglamentación de la Ley de Zonas Francas, estableciendo que la supervisión y control de zonas francas, sean privadas o estatales, está a cargo del MEF, y en particular del Área Zonas Francas, dentro de la Dirección General de Comercio. 


\section{Uruguay XXI. Su rol como promotor de exportaciones y de inversiones en la política comercial externa}

Como hemos observado, el Ministerio de Relaciones Exteriores tiene una Dirección General de Inteligencia, Promoción Comercial e Inversiones. Además, en Uruguay existe Instituto de Promoción de las Inversiones y Exportaciones de Bienes y Servicios (Uruguay XXI) que fue creado en 1996 mediante la Ley de Presupuesto del segundo gobierno del Dr. Julio María Sanguinetti. Nace como una persona pública no estatal y cuenta con los siguientes cometidos: realizar acciones de promoción en pos de la atracción de inversiones y el fomento de exportaciones; prestar información a potenciales inversores y a exportadores; asesorar al sector público respecto a acciones de promoción comercial en el exterior; y controlar el funcionamiento de la Ventanilla Única de Comercio Exterior.

El objetivo de Uruguay XXI es buscar fortalecer la imagen de Uruguay en el mundo, lograr consolidar una estrategia eficaz en la atracción de inversiones -enfocada en aquellos sectores prioritarios de la economía-, y ofrecer un apoyo cualitativo a las pequeñas y medianas empresas de bienes y servicios que deciden internacionalizarse. Uruguay XXI no participa directamente en negociaciones internacionales, sino que es un actor relevante al momento del aprovechamiento posterior de las preferencias negociadas.

En esta línea, Uruguay XXI se trata de un actor fundamental, y reconocido por distintos actores entrevistados, en la promoción de la oferta exportable nacional mediante la elaboración de materiales promocionales, la participación en ferias internacionales de referencia, y la organización de misiones comerciales empresariales a la región y por fuera de ella. Tiene la potencialidad para ser un agente colaborador en el diálogo públicoprivado y en la cooperación técnica.

Si uno compara las competencias de Uruguay XXI y aquellas de la DIPCI (Dirección de Inteligencia, Promoción Comercial e Inversiones), del Ministerio de Relaciones Exteriores, puede observarse un potencial solapamiento de funciones. La diferencia fundamental yace en la intensidad de la vinculación que tiene la DIPCI con las misiones de Uruguay en el exterior de las que tiene Uruguay XXI. DIPCI actúa como actor centralizador de información relevada por Embajadas y Consulados para luego derivarla a los actores pertinentes (ej. cámaras empresariales); así como de intermediario en el contacto de Uruguay XXI con Embajadas y Consulados. Asimismo, Uruguay XXI tiene una actitud más proactiva respecto a la vinculación con el empresariado local, por lo menos en lo que concierne a la promoción comercial y la formación de MIPYMES. La promoción comercial, que es un eslabón posterior de la cadena de la política comercia externa, requiere de un trabajo en conjunto con Cancillería, buscando aunar esfuerzos y, sobre todo, recursos humanos capacitados, que suelen ser escasos.

La máxima autoridad del Instituto es el Consejo de Dirección, conformado por los Ministros del MRREE (preside), MEF, MGAP, MIEM, MINTUR, y un representante de la Oficina de Planeamiento y Presupuesto. Es menester destacar que el Consejo Directivo quedó conformado con los mismos integrantes de la CIACEX. La gestión del Instituto y el día a día es llevada adelante por la Dirección Ejecutiva, compuesta por un director y un vicedirector ejecutivos. El cargo de Director Ejecutivo es designado por el Poder Ejecutivo a propuesta conjunta del MRREE y el MEF. 
El funcionamiento del Instituto se lleva adelante mediante las siguientes gerencias:

- Gerencia de Promoción de Exportaciones

- Gerencia de Promoción de Inversiones \& Aftercare

- Gerencia de Inteligencia Competitiva

- Gerencia de Comunicación \& Marketing

- Gerencia de Administración y Finanzas

\subsection{Distribución de competencias y organización institucional de la Politica Comercial Externa del Uruguay}

En base a lo investigado, y luego de numerosas entrevistas realizadas a distintos actores que hoy son parte -o que en pasadas administraciones han sido parte- de la cadena institucional de la política comercial externo, y siguiendo el modelo presentado por Bouzas en el 2020, presentamos la clasificación de la arquitectura institucional del Uruguay siguiendo las cuatro dimensiones que propone la metodología.

\subsubsection{Distribución de competencias entre los distintos poderes del Estado}

La Constitución de la República le confiere potestades específicas al Poder Ejecutivo y Poder Legislativo en materia de política comercial externa. Es responsabilidad del Poder Ejecutivo, en forma prácticamente exclusiva, la formulación e implementación de la PCE, siendo competencia del Poder Legislativo, y en última instancia, del Poder Judicial, ejercer las tareas de contralor y supervisión correspondientes. El artículo 168, numeral 20, es que le otorga, la autoridad de "concluir y suscribir tratados, necesitando para ratificarlos de la aprobación del Poder Legislativo." Ciertamente, cuando nos referimos al Poder Ejecutivo, lo hacemos a nivel nacional. Los gobiernos departamentales llevan adelante algunas acciones en el marco de la política exterior (misiones comerciales, hermanamientos, etc.), pero en última instancia, la PCE recae en manos del gobierno nacional.

El papel del Poder Legislativo, como lo señala el artículo 85 de la Constitución, es de contralor de las acciones del Ejecutivo, y específicamente, la aprobación (o no) de los tratados firmados por este. Es imperioso recordar que el Poder Legislativo cuenta con poder de veto sobre los convenios internacionales, incluyendo los acuerdos comerciales, al ser necesaria su aprobación, para que el Ejecutivo pueda ratificarlo y entre en vigencia. Señalamos, además, al inicio, lo expresado en el numeral 3 de este mismo artículo, que le da la posibilidad, al Poder Legislativo, de presentar proyectos de ley referidas al comercio exterior.

Por otra parte, mediante la Comisión de Asuntos Internacionales de la Cámara de Representantes o la Comisión homónima de la Cámara de Senadores, el Poder Legislativo hace seguimiento al accionar del Ejecutivo, contando con la potestad de hacer solicitudes de información y llamados a sala. Como ya hemos expuesto anteriormente, desde el retorno de la democracia tanto el Ministro de Relaciones Exteriores como el Ministro de Economía y Finanzas, dos actores claves en la PCE, han sido de los más interpelados por el parlamento. 
En términos de la autonomía o discrecionalidad que posee cada Poder para formular propuestas en torno a la PCE, el Poder Ejecutivo es quien centraliza la mayor responsabilidad en cuanto a las iniciativas, sobre todo en lo que refiere a las negociaciones comerciales internacionales. Sin embargo, la posibilidad que le da la Constitución de la República al Poder Legislativo de presentar leyes referidas al comercio exterior nos lleva a considerar que, el Parlamento, cuenta, al menos a nivel formal con instancias para influir en la formulación de propuestas que hacen a la PCE. Ciertamente, el Presidente de la República, en este caso, es quien tiene la última palabra, pudiendo usar su poder de veto.

Creemos oportuno, a partir de lo investigado y conversado con distintos actores, generar un mecanismo de articulación fluida sobre la base del respeto a la separación de poderes consagrado en nuestra Constitución.

\subsubsection{Distribución de competencias a la interna del Poder Ejecutivo: identificación de la "agencia líder" de la Política Comercial Externa}

A nivel de liderazgo de la PCE, en ausencia de normativa específica, así como de un Ministerio de Comercio Exterior, basándonos en la investigación realizada y las entrevistas llevadas adelante, podemos concluir que existe una fragmentación del liderazgo, encontrándose la institucionalidad uruguaya en una modelo de "competencias modulares"; la estructura presenta un liderazgo compartido entre el MRREE y el MEF, exigiendo mayores grados de concentración que si se diera el liderazgo por parte de un solo actor.

En este liderazgo compartido, la intervención de uno u otro Ministerio responde en gran medida al ámbito geográfico de la cuestión: a nivel de negociaciones o interacción con otros Estados u organismos internacionales, el MRREE es quien lidera la instancia, mientras que, a nivel nacional, sea en la articulación con privados o la fijación de la posición nacional, el MEF vía la APC es quien toma preponderancia. Más allá de esta división a grandes rasgos, a lo largo de las entrevistas encontramos en reiteradas instancias que el mayor o menor liderazgo de uno u otro ministerio depende del ministro de turno en términos de la relevancia asignada a la PCE, así como el relacionamiento personal entre ministros. En algunos casos se nos mencionó el peso que puede tener el MEF, en cuanto a que es la autoridad encargada de elaborar el presupuesto. Y, por tanto, su opinión es importante a la hora de tomar una decisión. En otros casos, se nos señalaba la importancia de que quienes ocupen el cargo en estos ministerios sean del "riñón" del Presidente de la República, para que esa coordinación sea más fluida.

Respecto a la promoción de exportaciones y la atracción de inversiones, Uruguay cuenta con una única agencia que concentra ambas funciones. En términos de los modelos de Bouzas (2020), entendemos que Uruguay XXI no es 100\% ninguno de los tres modelos jurídicos-administrativos: dependencia ministerial; agencia estatal autárquica; o agencia mixta público-privada. A nuestro parecer, Uruguay XXI presenta elementos tanto de una agencia estatal autárquica como de una agencia mixta público privado.

Siendo una persona pública no estatal, la agencia no es una dependencia ministerial, acercándose al modelo de agencia estatal autárquica. Asimismo, goza de cierta autonomía respecto al MRREE (quien preside su Consejo Directivo), pero siempre actúa en coordinación y en línea con el Plan Estratégico previamente aprobado. En términos de su 
gobernanza, a partir de la Ley de Presupuesto de la vigente administración, el Consejo Directivo quedó compuesto $100 \%$ por actores estatales, siendo los actores privados relegados a una Consejo Asesor aún sin definir. Sin embargo, acercándose al modelo mixto público - privado, sus fuentes de financiación pueden ser mixtas y las políticas salariales y de contratación son independientes a las estatales.

También es cierto que, como señalamos anteriormente, el Ministerio de Relaciones Exteriores cuenta con una Dirección de Inteligencia, Promoción Comercial e Inversiones. Es este un espacio que necesita de diálogo y coordinación que aúne recursos y esfuerzos en la tarea fundamental que cumplen en materia de política comercial externa, fundamentalmente, en la etapa posterior a la firma de acuerdos comerciales o, en ausencia de ellos, al acceso a mercados.

\subsubsection{Agencias públicas subsidiarias que participan en ese espacio de política, así como la modalidad predominante de coordinación/interacción}

El carácter multidimensional que posee la PCE genera el involucramiento de actores gubernamentales vinculados a distintas políticas públicas en su formulación e implementación por fuera de sus principales articuladores, el eje MRREE-MEF. A nivel gubernamental en el apartado anterior hicimos referencia al MGAP, MIEM; MINTUR, Ministerio de Ambiente, OPP, INALE e INAC. Sin embargo, es menester destacar que existe una amplia gama de otros actores que también participan en cuestiones más bien sectoriales, pero por cuestiones de extensión de esta investigación nos hemos limitado a los actores previamente mencionados.

A nivel de coordinación gubernamental, independientemente de la temática en cuestión, la instancia máxima de coordinación es el Consejo de Ministros, momento en el que se reúne la totalidad del Poder Ejecutivo. En cuanto a la PCE, a pesar de su letargo, la CIACEX es la instancia de mayor importancia al reunir a todos los ministros involucrados en asuntos relativos a la inserción económica comercial de nuestro país. Siguiendo a la CIACEX, y en un menor nivel jerárquico, pero no de importancia, se encuentra la Sección Nacional, instancia técnica que reúne a casi todos los mismos integrantes de la CIACEX y que se creó para el abordaje de asuntos comerciales relativos al Mercosur.

Por fuera de estos dos ámbitos, pueden darse instancias de coordinación interministerial ad-hoc, en reuniones bilaterales o plurilaterales, así como instancias de articulación a nivel técnico para generar consensos sobre materias específicas como se da con las mesas sectoriales, y, con otro nivel de formalidad, mediante la creación de Procarnes y la potencial creación de Prolácteos.

Respecto a las tres posibilidades de modelos de articulación y coordinación entre agencias estatales que propones Bouzas (2020), a partir de las entrevistas realizadas, hemos podido constatar que, en la mayoría de ellas, se ha hecho particular hincapié en la escala de Uruguay como facilitador de la interacción entre actores involucrados de la PCE. Se entiende que la pequeñez de nuestro país, y la cercanía entre instituciones, por lo menos a nivel técnico, facilita la comunicación y compensa potenciales cortocircuitos a nivel de cúspides jerárquicas. En cierta medida, se destacaba la "informalidad" como una ventaja a la hora de coordinar. Tomando esto en cuenta, la institucionalidad uruguaya se encuentra en un punto medio entre una modalidad "colaborativa" y de "redes". Existe 
un grado de confianza que facilita la interacción, que se lleva adelante sobre todo de manera ad-hoc y no a través de instancias formales de coordinación. Esto, para algunos entrevistados, es un problema que tienen el Uruguay, por cuanto no ayuda a la creación de una memoria institucional que facilite los procesos en el largo plazo. Uno de ellos, expresaba con alarmismo, el uso que se le estaba dando al WhatsApp como herramienta de coordinación y consulta.

A nivel de promoción de exportaciones y atracción de inversiones, los modelos de articulación se asemejan a las instancias de la PCE en general. A nivel técnico existe un diálogo fluido, especialmente en lo que concierne a las instituciones involucradas en el ecosistema exportador, comenzando con Uruguay XXI y siguiendo por la Agencia Nacional de Desarrollo, la Agencia Nacional de Innovación, el Instituto Nacional de Empleo y Formación Profesional, el Laboratorio Tecnológico del Uruguay, entre otros. A nivel ministerial, la derogación de Transforma Uruguay, puede significar la pérdida de una instancia de articulación macro.

\subsubsection{Modalidad de participación/intervención de los actores privados relevantes en el proceso de formulación e implementación de la PCE, transparencia y mecanismos de consulta}

Dadas las dimensiones que hoy por hoy abarca la PCE, existen una plétora de actores no estatales que en mayor o menor medida se ven afectados por decisiones a nivel de la inserción económica comercial de nuestro país. En secciones anteriores hemos hecho referencia algunos que por su capacidad de influencia a nivel gubernamental entendíamos que era imprescindible incluirlos. Entendemos que, a nivel de la economía, así como a nivel de la sociedad civil, estos son los actores que articulan el interés de la mayor parte del sector productivo.

A nivel formal no hemos identificado una instancia de diálogo o articulación creada específicamente para que el gobierno releve los intereses de los principales interlocutores del sector privado o del sector sindical. No existe una "CIACEX ampliada" de la que participen tanto públicos como privados; lo más cercano a esto son los Consejos de Dirección de distintos Institutos como INAC, INALE e INAVI. Estas instancias son, por cierto, positivas, pero fragmentadas por sectores y no permiten ofrecer una mirada global sobre toda la política comercial externa del Uruguay. A modo de ejemplo, un elemento que ha llamado la atención es la articulación y coordinación de INAC, desarrollando incluso ellos, las tareas de promoción comercial.

Que no exista una instancia formal de coordinación, no significa que el gobierno no esté en constante interacción con el sector productivo y sindical. De hecho, se nos ha mencionado en diversas oportunidades, seguramente por eso idea de "Uruguay país pequeño en el que nos conocemos todos", que hay acceso a dialogar con un Ministro muy fácilmente. Lo que esto revela, simplemente, es la falta de una instancia específica, con reuniones periódicas, en las que estas puedan participar proactivamente, y de manera articulada, de la formulación e implementación de la PCE.

Las instancias de mayor diálogo se dan impulsadas por situaciones coyunturales, donde el sector privado transmite una preocupación directamente al gobierno, o por el ingreso de Uruguay a negociaciones, sean a nivel de Mercosur o bilateralmente en 
aspectos sanitarios, de inversiones o tributarios. El sector privado es tenido en cuenta, pero al igual que establecimos para la coordinación entre actores a nivel público, la interacción público-privada suele darse por vías informales.

A nivel de la sociedad civil, como ya se ha expuesto, en el año 2014, en la esfera del MRREE se crea el Sistema de Diálogo y Consulta (SDC) con el objetivo de democratizar el acceso a la información y generar instancias de intercambio respecto a la política exterior en general. Sin embargo, desde diciembre del 2019 no se cuenta con registro de actividades ni de noticias, por lo que se entiende que bajo la nueva administración este mecanismo no ha tenido continuidad.

En cuanto a la taxonomía propuesta en el trabajo de Bouzas (2020), el grado de involucramiento de actores no estatales en la PCE puede categorizarse como de "club adaptado"; la articulación se da entre un número reducido de actores donde las autoridades gubernamentales actúan de manera pragmática, buscando acotar las asimetrías de la información existentes en cuanto al sector productivo, sus necesidades y preocupaciones. Argumentos a favor de esta categorización también se encuentran respecto a las nulas instancias de intercambio de alto nivel establecidas formalmente. 


\title{
Capítulo 5. Estudio de otros diseños institucionales en la política comercial externa. Una experiencia comparada
}

\author{
“Todo el mundo tiene la fortuna entre las manos, \\ como un escultor que maneja el material que \\ transformará en una figura... Es necesario aprender \\ y cultivar atentamente la habilidad para moldear \\ el material y darle la forma que queramos."
}

Johann Wolfgang Von Goethe

\subsection{Introducción}

Cuando uno se plantea realizar un análisis comparado en un trabajo de investigación, inmediatamente se ve tentando a querer reproducir las recetas exitosas a su realidad, olvidándose del contexto particular de cada país los cuales, generalmente, son una condicionante. No es lo mismo la ubicación geográfica de Nueva Zelanda -una isla ubicada en el pacífico, muy cerca de los principales mercados que hoy demandan alimentos-, o la estrategia de apertura económica-comercial llevada adelante por Chile durante 30 años, que la realidad y el contexto en el que Uruguay desarrolla su estrategia de inserción. Somos un país ubicado entre las dos economías emergentes más proteccionistas (Argentina y Brasil) e inmersos en un bloque regional paralizado. Sin embargo, resulta indispensable realizar el ejercicio de salir de uno mismo, poder mirar más allá de la realidad coyuntural, tener la mente abierta, y con vocación de aprendizaje, conocer y reflexionar sobre los caminos que otros ya recorrieron y sobre los cuales la evidencia empírica muestra resultados satisfactorios.

En este capítulo, proponemos fijar la mirada en dos países: Nueza Zelanda y Chile. Dos países con sistema de gobierno diferentes y con distintos arreglos institucionales en su política comercial externa, pero, con un notorio desempeño positivo en materia de comercio internacional. En la última década, se ha escuchado con frecuencia que Uruguay debería seguir el modelo de uno u otro país. Nosotros, en las páginas siguientes proponemos analizar cómo estos países han diseñado su estructura institucional a la hora de planificar su política comercial externa.

\subsection{NUEVA ZELANDA: Una estructura orientada hacia la apertura al mundo}

En muchas ocasiones se han desarrollado diversos estudios comparativos entre Nueva Zelanda y Uruguay. El análisis comparado resulta muy atractivo para diversos especialistas e investigadores. Se han escrito artículos, pero también tesis doctorales e incluso libros. Los dos países están situados en una zona geográfica similar -ambos entre los paralelos 30 y 47-, y si bien Nueva Zelanda tiene mayor superficie $(267.710 \mathrm{~km} 2)$ y población (5.090.000) respecto a Uruguay (176.220 km2 y 3.461 .734 habitantes), comparten cierta similitud en las principales áreas productivas. Los dos países poseen un clima templado, gran cantidad de tierra con relación a la población y una fuerte influencia de la inmigración europea (Álvarez y Bértola, 2010). 
Nueva Zelanda es una economía pequeña y abierta que históricamente ha promovido el comercio exterior como motor de su economía. Su énfasis en la apertura comercial ha llevado a que en las últimas décadas haya logrado negociar acuerdos comerciales con sus principales socios comerciales y que tenga una apertura comercial del 96.2\%. De acuerdo a las últimas cifras conocidas, al 2018, las exportaciones de bienes y servicios representaban el $55,9 \%$ de su PBI.

\subsubsection{Estructura Institucional de la politica comercial externa de Nueva Zelanda}

\section{Distribución de competencias entre los distintos poderes del Estado}

Desde su independencia del Reino Unido en 1947, Nueva Zelanda, de manera semejante a Australia y Canadá, es una monarquía constitucional con un sistema parlamentario unicameral.

El principal representante de Nueva Zelanda en el mundo es el Primer Ministro, seguido por el Ministro de Relaciones Exteriores, responsable del Ministry of Foreign Affairs and Trade (MFAT por sus siglas en inglés). En sus tareas relativas al comercio internacional, el Ministro es apoyado por el Ministro de Comercio Internacional y Promoción de Exportaciones, también integrante del Ministry of Foreign Affairs and Trade.

En términos de la autonomía o discrecionalidad que posee cada Poder para formular propuestas relativas a la política comercial externa, el Poder Ejecutivo aglomera prácticamente todas las instancias de iniciativa, siendo clave la obtención de mandatos a nivel de gabinete para poder iniciar negociaciones internacionales. Cualquier Ministerio puede llevar adelante negociaciones, siempre con el MFAT coordinando esfuerzos. Por su parte, al igual que en la mayoría de los sistemas republicanos, el rol del poder legislativo es fundamental para la interiorización de los compromisos alcanzados, así como en el contralor de la política exterior.

\section{Ubicación, formato institucional y características de la "autoridad principal" (o líder) en el espacio de política pertinente}

Al momento de la formulación e implementación de la política comercial neozelandesa, el principal actor gubernamental, como ya se ha adelantado, es el Ministry of Foreign Affairs and Trade. El MFAT cuenta con cuatro principales áreas de acción para las que el gobierno designa un ministro: Foreign Affairs (Relaciones Exteriores); Trade and Export Growth (Comercio y Promoción de Exportaciones); Disarmament and Arms Control (Desarme y Control de Armas); y Climate Change (Cambio Climático). Los Ministros de Relaciones Exteriores y Comercio, y Promoción de Exportaciones son aquellos con mayor preponderancia a la interna del organismo.

A efectos de la metodología utilizada en esta investigación, Nueva Zelanda tiene un modelo de "competencias concentradas", estando el liderazgo de la política comercial externa centralizado en una sola cartera gubernamental; más allá de la coordinación lógica con otros actores del Estado.

Por fuera de las negociaciones, en el aprovechamiento de los acuerdos negociados, la agencia de promoción de exportaciones y atracción de inversiones neozelandesa juega un papel fundamental como aliado del empresariado exportador. Creada en el 2003, New Zealand Trade \& Enterprise es una Crown Entity cuya responsabilidad es del Ministro 
de Economía y Desarrollo Regional, así como del Ministro de Comercio y Promoción de Exportaciones.

Se trata de una "agencia estatal autárquica", es decir, una agencia independiente de jerarquía ministerial. Concentra en una sola entidad tanto la promoción de exportaciones como la atracción de inversiones que, hasta el momento de su creación, eran funciones llevadas adelante de manera independiente.

Agencias públicas subsidiarias que participan en ese espacio de política, así como la modalidad predominante de coordinación/interacción

Al igual que sucede en todos los países, las "agencias líderes" requieren de asesoramiento especializado para diversos asuntos abordados en negociaciones internacionales como propiedad intelectual, compras gubernamentales, asuntos sanitarios y fitosanitarios, etc. Nueva Zelanda no escapa de esta regla, apoyándose el MFAT en distintos ministerios y agencias gubernamentales como el Ministry of Business, Innovation \& Employment (MBIE - Ministerio de la empresa, innovación, y empleo), el Ministry for Primary Industries (MPI - Ministerio de Industrias Primarias), el New Zealand Treasury (Ministerio de Hacienda), el Ministry for the Environment (Ministerio de Medio Ambiente), y New Zealand Customs Service (aduana de Nueva Zelanda).

Más allá del gabinete reunido en su totalidad, el contralor y la toma de decisiones respecto a la política exterior y la política comercial de Nueva Zelanda es llevada adelante en el gabinete a través del External Relations and Security Committee así como en el Economic Development Committee; ambas instancias son gabinetes interministeriales con distintas configuraciones. Estas se tratan de instancias a nivel ministerial, por fuera de estas existen instancias paralelas de coordinación periódica por parte de técnicos y mandos medios.

De acuerdo con la metodología que expresamos en el marco teórico, y que venimos siguiendo en nuestro análisis, la modalidad de coordinación entre actores puede catalogarse como "jerárquica", existiendo una instancia suprema de coordinación entre ministros, que luego lleva a distintas acciones a nivel de la tecno burocracia neozelandesa.

\section{Modalidad de participación/intervención de los actores privados relevantes en el proceso de formulación e implementación de la PCE, transparencia y mecanismos de consulta.}

En búsqueda de mayor transparencia y apoyo popular para una política comercial externa verdaderamente inclusiva, en el 2018, el gobierno neozelandés estableció la Trade for All Advisory Board cuyo objetivo era conjugar en una misma instancia de intercambio, a distintos actores de la sociedad civil neozelandesa. El objetivo de esta entidad era la elaboración de un informe acerca del estado de situación actual de la política comercial de Nueva Zelanda en cuanto a su cercanía con la sociedad.

Específicamente tras el informe presentado por la Trade for All Advisory Board, el MFAT buscó profundizar las instancias de interacción con distintos componentes de la sociedad neozelandesa; en esta línea, el gobierno ha buscado tener una actitud proactiva en cuanto a la difusión de la mayor información posible respecto a negociaciones vigentes y potenciales, manteniendo la posibilidad de consultas abiertas durante todas las fases de negociación. Precisamente, es en estas instancias que grupos de interés domésticos como cámaras empresariales, sindicatos, organizaciones no gubernamentales, y como particularidad neozelandesa, el pueblo maorí, pueden transmitir sus preocupaciones. 
Dados los pasos que ha tomado Nueva Zelanda en los últimos años, la proactividad demostrada respecto a adelantarse a las preocupaciones que pueda llegar a tener la sociedad civil, la información que pone a disposición en todo momento, y los procesos de consulta existentes a nivel formal e informal, metodológicamente podemos catalogar al modelo de interacción con actores no estatales como "multistakeholder". Nueva Zelanda ha asumido el compromiso, y ha actuado conforme, a que la política comercial debería ser un desafío encarado con un enfoque inclusivo, haciendo hincapié en darle mayor lugar a actores previamente relegados como el pueblo maorí, las MIPYMEs, sindicatos, y mujeres.

\subsection{CHILE: Flexibilidad. Dinamismo. Proactividad}

La arquitectura institucional de Chile ha atravesado diversas y sustanciales transformaciones, que han sido producto del aumento constante de su volumen de actividades, como respuesta a la estrategia de apertura en su inserción económicacomercial. Al analizar el proceso de Chile, en materia económica-comercial, parece haber una constante: la búsqueda incesante de creación de instancias especializadas para fortalecer su accionar como respuesta a las nuevas dinámicas que se van produciendo en el mundo. Esto se puede lograr porque se parte de un consenso nacional sobre la política comercial de inserción en el mundo.

De acuerdo con lo publicado por la Subsecretaría de Relaciones Económicas Internacionales, a febrero de 2021, Chile cuenta con 30 acuerdos comerciales vigentes. Los 30 acuerdos implican a 65 economías, lo que representa el $88 \%$ del Producto Interno Bruto (PIB) mundial. Más aún, los productos de Chile llegan un mercado que contiene cerca del $70 \%$ de la población mundial. Es el país con la red de tratados de libre comercio con mayor acceso al PIB mundial, según datos de la OCDE. Además, a abril de 2021, tiene cuatro acuerdos ya suscritos que se encuentran a la espera de la firma o entrada en vigor; y ocho acuerdos en negociación, alguno de los cuales son de profundización o modernización de los ya existentes, como sucedió con el Tratado de Libre Comercio con Uruguay, ratificado en 2018.

\subsubsection{Estructura Institucional de la política comercial externa de Chile}

\section{Distribución de competencias entre los distintos poderes del Estado}

La Constitución que rige en la actualidad en Chile, es la aprobada en 1980. Tiene un régimen político republicano, democrático y representativo, con un gobierno de fuerte impronta presidencial. El Estado está dividido en tres poderes independientes: Ejecutivo, Legislativo y Judicial.

Dentro del Poder Ejecutivo, como se expresa en la reciente ley N 21.080 , aprobada en 2018, corresponde al Presidente de la República, en colaboración con el Ministerio de Relaciones Exteriores, la formulación e implementación de la política comercial externa. En efecto, así lo expresa el artículo $1^{\circ}$ de la mencionada ley: al Ministerio de Relaciones Exteriores le corresponde "colaborar con el Presidente de la República en el diseño, planificación, prospección, conducción, coordinación, ejecución, control e información de la política exterior que éste formule..." Este artículo, en conjunto con el $4^{\circ}$, claramente refleja la importancia del Presidente de la República en materia de política exterior, que como ya hemos visto, comprende a la política comercial.

Respecto al Poder Legislativo, Chile tiene una estructura bicameral, con atribuciones fiscalizadoras y colegisladoras, está compuesto por el Senado y la Cámara de Diputados. A 
su vez, cada una de las Cámaras tiene un sistema de trabajo por comisiones especializadas en los diversos temas que hacen a la agenda de políticas públicas. En materia de política exterior, el Senado cuenta con existencia de la Comisión de Relaciones Exteriores y en Diputados, la Comisión de Relaciones Exteriores, Asuntos Interparlamentarios e Integración Latinoamericana.

El papel del Congreso Nacional de Chile, en materia de política comercial, está limitado por el artículo 54, numeral primero de la Constitución de la República, a la aprobación o rechazo de los acuerdos internacionales que hayan sido firmados por el Gobierno Nacional. No existe el derecho a modificar su contenido. Una vez firmado el Tratado, el Presidente de la República envía un Mensaje al Congreso con el objetivo, contenido y beneficios del nuevo tratado. Una vez ingresado al Congreso, el tratamiento es el mismo que los proyectos de ley. Sin perjuicio de que no existe la posibilidad de modificación del contenido, es frecuente la participación del Ministro de Relaciones Exteriores o el Subsecretario de Relaciones Económicas Internacionales a las respectivas comisiones del Senado y/o de la Cámara de Diputados para exponer sobre determinados asuntos de interés en materia de política comercial externa. Ha existido siempre una preocupación, por parte de los gobiernos, sobre la viabilidad política interna de los tratados, y por eso, se procura interiorizar al Congreso durante el proceso de negociación para poder asegurar la aprobación futura.

\section{Ubicación, formato institucional y características de la "autoridad principal" (o líder) en el espacio de política pertinente}

El 20 de marzo de 2018 entró en vigor la Ley 21.080 que modifica diversos cuerpos legales con el propósito de modernizar el Ministerio de Relaciones Exteriores de Chile. Ha sido la última transformación realizada para establecer la estructura institucional vigente en materia de política comercial externa. Uno de los aspectos centrales de esta actualización, fue la creación de una Subsecretaría de Relaciones Económicas Internacionales, sucediendo a la Dirección General de Relaciones Económicas Internacionales (DIRECON).

El artículo 27 de la ley que moderniza el Ministerio de Relaciones Exteriores (Ley No21.080), define a la Subsecretaría de Relaciones Económicas Internacionales como "el órgano de colaboración inmediata del Ministro de Relaciones Exteriores en materia de relaciones económicas internacionales, al que le corresponderá la coordinación con los órganos de la Administración del Estado con competencia en dicha materia..." A partir del 1 de julio de 2019, esta Subsecretaría se convirtió, oficialmente, en la sucesora de la DIRECON.

Al analizar la estructura institucional de Chile es posible identificar, por un lado, al Ministerio de Hacienda que tiene como uno de sus objetivos estimular la integración económica internacional, y que, bajo la órbita del Subsecretario de Hacienda se encuentra la Coordinación de Facilitación de Comercio y Política Comercial. Y, por otro, al Ministerio de Relaciones Exteriores, con un área -la Subsecretaría de Relaciones Económicas Internacionales- bajo cuya estructura se encuentra toda el área de inserción económica-comercial. Sin embargo, cuando se entra en detalle, quien predomina como autoridad principal o "líder" dentro del Poder Ejecutivo, para llevar adelante la implementación de la Política Comercial Externa, es la Subsecretaría de Relaciones Económicas Internacionales. 
En base a la propuesta metodológica de Bouzas, entendemos que se trata de un liderazgo de "competencia concentrada". Es cierto que la estructura establece claramente las instancias para la coordinación y el diálogo con los otros ministerios, con el poder legislativo y/o con otras agencias, pero en todos esos casos, se percibe que el organismo rector es el Ministerio de Relaciones Exteriores. En ese sentido, el nivel de compartimiento que se puede observar no implica una ineficacia de la estructura, sino un balance entre la especialización y la necesaria coordinación para poder cumplir los objetivos.

El otro punto que señala Bouzas dentro de la categoría del liderazgo de la política comercial externa, refiere a las agencias de promoción de las exportaciones y las inversiones. A diferencia de lo que sucede en otros países, por ejemplo, en Uruguay con la agencia Uruguay XXI, en Chile la función de promoción de exportación y la de promoción de la inversión extranjera directa están desagregadas. Existe un debate en la literatura sobre las ganancias potenciales de tener ambas tareas bajo una misma agencia o no. Chile ha optado por la especialización y diferenciación de las funciones. El punto de coincidencia entre las dos áreas es la "dependencia ministerial". En el caso de las inversiones, mediante el organismo InvestChile (que veremos en el apartado siguiente), dependiente del Ministerio de Economía, Fomento y Turismo. Y en el caso de la promoción de exportaciones -Prochile-, la Ley N²1.080, creó la Dirección General de Promoción de Exportaciones dentro del Ministerio de Relación Exteriores, en la órbita de la Subsecretaría de Relaciones Económicas Internacionales.

\section{Agencias públicas subsidiarias que participan en ese espacio de política, así como la modalidad predominante de coordinación/interacción}

El 10 de mayo de 1995, el Decreto No. 419 del Ministerio de Relaciones Exteriores había creado el Comité Interministerial de Relaciones Económicas Internacionales cuya función principal era asesorar y proponer al Presidente de la República las políticas específicas en materia de negociaciones económicas internacionales. El artículo 9 de la ley 21.080 dispone algunas modificaciones legales. Señala que el Ministro de Relaciones Exteriores:

constituirá un comité asesor, denominado Comité Interministerial de Negociaciones Económicas Internacionales, cuya función será apoyarlo en su misión de colaborar con el Presidente de la República en la planificación, conducción, coordinación, ejecución, control e información de la política exterior relativa a las negociaciones económicas internacionales y al cumplimiento de las obligaciones derivadas de éstas.

El Subsecretario de Relaciones Económicas Internacionales, actúa como Secretario Ejecutivo del Comité. A su vez, el Presidente del Comité tiene la facultad de invitar a funcionarios públicos, asesores, expertos, académicos o personas del sector privado o de la sociedad civil en función de las materias que se traten.

Por fuera de la órbita del Ministerio de Relaciones Exteriores, dentro del Ministerio de Hacienda, Chile cuenta con un Sistema Integrado de Comercio Exterior (SICEX). Una unidad cuyo objetivo es asesorar al Ministerio de esta cartera en el liderazgo, la coordinación y la gestión de las diversas iniciativas públicas y/o privadas que estén orientadas a facilitar el comercio exterior del país, potenciando la capacidad exportadora y fortaleciendo la integración comercial del país. 
A partir de lo estudiado, entendemos que la modalidad que mejor representa el caso de Chile es la que Peters (2018) ha dado en llamar modalidad "jerárquica". Como ya hemos señalado, la coordinación se produce en el Comité Interministerial de Negociaciones Económicas Internacionales. Esté Comité es presidido por el Ministro de Relaciones Exteriores y, cuyo Secretario Ejecutivo es el Subsecretario de Relaciones Económicas Internacionales.

La modalidad "jerárquica" señalada, en cierta medida, responde a la forma que Chile ha dado a su estructura institucional en materia de PCE y que ya hemos consignado. Más allá de esa modalidad, entendemos oportuno señalar que también observamos rasgos de la modalidad "colaborativa" que se ha ido construyendo a lo largo del tiempo, alineándose todas las partes atrás de una estrategia común de apertura comercial cuyos resultados favorables se han ido reconociendo negociación tras negociación, ayudando a fortalecer ese vínculo. Incluso, en esta modalidad de colaboración, las distintas partes, han acordado la forma en cómo resolver las situaciones en las que no hay acuerdo como hemos señalado. La ampliación de temas que hoy hacen a la política comercial en una negociación internacional necesariamente implica la colaboración y la incorporación de los conocimientos técnicos específicos. Vemos que Chile, combinando la modalidad "jerárquica" y la modalidad "colaborativa", ha logrado dar respuestas.

\section{Modalidad de participación/intervención de los actores privados relevantes en el proceso de formulación e implementación de la PCE, transparencia y mecanismos de consulta.}

El último punto que presenta Bouzas en su metodología es la modalidad de participación o intervención de los actores no-estatales, es decir, de las organizaciones empresariales, los sindicatos, las organizaciones de la sociedad civil, la academia. Bouzas propone la taxonomía prevista por Hocking, 2004. En base a ella, a nuestro criterio la PCE en Chile tiene una combinación del modelo de "club adaptado" y el modelo "multistakeholders". Como hemos visto, existen numerosos mecanismos de participación ciudadana previstos en la Subsecretaría de Relaciones Económicas Internacionales. A su vez, es potestad del Presidente del Comité Interministerial de "invitar a funcionarios públicos, asesores, expertos, académicos o personeros del sector privado o de la sociedad civil de reconocida versación sobre las materias que se traten", como señala el artículo cuatro del Decreto 135 de agosto de 2019. Las múltiples partes interesadas tienen la posibilidad de participar y expresar sus intereses, sus preocupaciones, sus propuestas mediante mecanismos formales y debidamente institucionalizados. En cierta medida, esto ayuda a legitimar los procesos que hacen a la formulación e implementación de la política comercial externa. Por otra parte, el mecanismo del "Cuarto Adjunto", es un mecanismo considerado clave en Chile dentro de la etapa de negociación comercial. Con reuniones periódicas antes y después de cada ronda de negociación permite intercambiar la información y los distintos puntos de vista de los distintos actores no estatales. Responde a una política prioritaria de transparencia que permite la aclaración de dudas y la búsqueda, por parte de los negociadores, de incluir los aportes de los distintos actores. En la entrevista realizada al Dr. Heine, para esta investigación, nos señalaba precisamente, "la necesidad de buscar mecanismos más formales, amplios, democráticos y participativos en torno a la PCE." 


\title{
Capítulo 6. Conclusiones, recomendaciones y reflexiones finales
}

\author{
"Son tus decisiones, no tus condiciones, \\ las que determinan tu destino.'
}

Tony Robbins

Luego de varios meses de investigación, numerosas entrevistas a distintos actores de la realidad nacional e internacional, presentamos nuestras conclusiones buscando contribuir al desarrollo de la literatura existente en la materia y al debate nacional sobre la necesidad de una modernización institucional de la política comercial externa del Uruguay, que le permita llevar adelante una estrategia de inserción internacional dinámica, flexible y proactiva, en la búsqueda siempre de seguir avanzando al tan deseado desarrollo como nación.

\section{1 Conclusiones generales}

El objetivo general de esta investigación ha sido contribuir a la mejora de la estrategia de inserción internacional del Uruguay desde el punto de vista de su estructura institucional, buscando que la misma sea capaz de facilitar los procesos de integración comercial (acuerdos para el "desarrollo"), el acceso a mercados, y la atracción de flujos de inversión. Para poder cumplir con este objetivo general, nos planteamos una pregunta central de investigación: ¿existe hoy una estructura institucional abocada a la inserción económica-comercial internacional del Uruguay? De esta pregunta, se desprenden otras dos directamente relacionadas a su respuesta: En el caso de que exista una estructura institucional, ¿se adapta a los desafíos que el mundo actual le exige hoy a Uruguay? Y si no se adapta, ¿cuáles deberían ser los pilares centrales sobre los cuales diseñar estratégicamente dicha estructura?

En respuesta a la pregunta central de la investigación, efectivamente existe una estructura institucional abocada a la inserción económica-comercial del Uruguay. Dicha estructura es el resultado de un proceso constructivo que se ha ido desarrollando a lo largo de nuestra historia como nación. Existe una gran dificultad por introducir procesos de transformación a nivel de estructura general del funcionamiento del Estado. No existe una visión clara ni consensuada sobre la necesidad de una modernización institucional del Estado. Como resultado, se van introduciendo cambios parciales, sin una mirada integral de las necesidades del país en el presente y, sobre todo, en el futuro. La construcción del país que se quiere, implica una estrategia y unas decisiones hoy. Con la política comercial externa, desde el nacimiento del Mercosur se han ido realizando algunos cambios que estuvieron fuertemente condicionados por nuestra presencia en el bloque y, en cierta medida, siempre se trataron de cambios parciales, sin una mirada integral de la política comercial externa.

Siguiendo el modelo de Bouzas (2020) que hemos decidido aplicar como metodología de nuestra investigación, los arreglos institucionales de nuestra Política Comercial Externa son los siguientes: 
A. Distribución de competencias entre los distintos poderes del Estado

- La Constitución de la República le confiere potestades específicas tanto al Poder Ejecutivo como al Poder Legislativo en materia de política comercial externa. Sin embargo, es el Poder Ejecutivo quien tiene la primacía y mayor responsabilidad en la formulación e implementación de esta.

- El rol del Poder Legislativo, más allá de tener iniciativa parlamentaria para promover leyes referidas al comercio exterior (Art.85, numeral 3), está referido al poder de veto que le otorga la Constitución sobre los convenios internacionales, incluyendo los acuerdos comerciales.

- La relación entre el Poder Ejecutivo y el Poder Legislativo, puede darse mediante la solicitud de información, el llamado a Comisión de Asuntos Internacionales de ambas Cámaras o la interpelación, por parte del Poder Legislativo. De hecho, desde el retorno a la democracia hasta la fecha tanto el Ministro de Relaciones Exteriores como el Ministro de Economía y Finanzas han sido los más interpelados por el Parlamento Nacional.

B. Distribución de competencias a la interna del Poder Ejecutivo

- La política comercial externa del Uruguay presenta una fragmentación en su liderazgo, con una distribución de competencias modulares entre el Ministerio de Relaciones Exteriores y el Ministerio de Economía y Finanzas. Este liderazgo se ha visto variar en función del momento en que se esté del proceso, pero también en función de las personas, el relacionamiento personal de los ministros y el peso político interno que estos tengan dentro del gobierno de turno.

- Uruguay no cuenta con un Ministerio de Comercio Exterior como sucede en otros países. Esto no ha sido visto como una necesidad ni como un problema durante la investigación. La necesidad pasa por una mayor coordinación y trabajo en equipo, empoderando a los actores vigentes con estructuras sólidas, más que por la creación de burocracia adicional.

- La promoción de exportaciones y atracción de inversiones están concentradas en Uruguay XXI, más allá de que existen otros espacios que realizan esta tarea (la Dirección de Inteligencia y Promoción Comercial e Inversiones del Ministerio de Relaciones Exteriores o institutos sectoriales como en el caso de INAC, por ejemplo). A nuestro juicio, Uruguay XXI no representa 100\% ninguno de los tres modelos jurídicoadministrativos presentados por Bouzas. Tiene una combinación, mayoritariamente, de una agencia estatal autárquica y una agencia mixta público-privada.

C. Agencias públicas subsidiarias que participan en el espacio de la política comercial externa. Modalidad predominante de coordinación-interacción

- El creciente número de áreas y el enfoque multidimensional que han adquirido las relaciones internacionales, genera una necesidad de mayor grado de planificación, coordinación y articulación para poder ofrecer una gestión estratégica y eficiente. Hemos constatado la existencia de un número importante de actores gubernamentales y sectoriales.

- La Comisión Interministerial para Asuntos de Comercio Exterior (CIACEX) es, a nivel formal, la instancia de mayor importancia de coordinación a nivel ministerial. 
Decimos a nivel formal porque, al cierre de esta investigación (mayo 2021), no ha surgido información pública de que la misma haya sido convocada por la actual administración. Esto ha sido confirmado por algunos entrevistados.

- Otro espacio de coordinación identificado, aunque de menor nivel jerárquico y con un enfoque técnico, es la Sección Nacional del Mercosur, creada para abordar los asuntos comerciales del bloque.

- En la investigación también hemos podido constatar, instancias de coordinación interministerial ad-hoc y mesas sectoriales como puede ser el caso de Procarnes, por ejemplo.

- Concluimos, a partir de las entrevistas realizadas, que se hace particular hincapié en la escala de Uruguay ("país pequeño que nos conocemos todos") como argumento que facilita la interacción informal entre los actores involucrados, observándolo como una ventaja a la hora de coordinar. Sin embargo, esto va en contra, según lo consignaban algunos entrevistados, con la idea de crear una memoria institucional que facilite procesos de largo plazo que no estén arraigados en personas, sino en estructuras sólidas. A modo de ejemplo, la presencia del WhatsApp, como herramienta de coordinación y consulta, puede ser vista como un elemento positivo, ágil y facilitador, pero que, desde un enfoque institucionalista, genera cierto alarmismo.

- Entendemos que Uruguay se encuentra en un punto medio entre una modalidad "colaborativa" y una modalidad de "redes", de acuerdo a Bouzas, sobre todo si lo observamos en la relación de los dos ministerios líderes con otros ministerios o agencias.

D. Modalidad de participación de los actores privados relevantes en el proceso de formulación e implementación de la política comercial externa. Transparencia y mecanismos de consulta

- Existe una plétora de actores no estatales que, en mayor o menor medida, se ven afectados por la política comercial externa. En el capítulo anterior hemos citado solo algunos.

- No se identifica un espacio institucionalizado para la coordinación y articulación de los actores privados (organizaciones empresarias, sindicatos, organizaciones de la sociedad civil, academia) con el gobierno. Identificamos, como algo positivo, los Consejos de Dirección de Institutos como INAC, INALE o INAVI, en los que están todos los actores representados, tanto públicos como privados. Sin embargo, son espacios fragmentados a nivel sectorial que no permiten generar una mirada global sobre la política comercial externa del Uruguay.

- Cuando no hay diálogos institucionalizados no se dan garantías de estar interactuando con todos. No significa que no exista interacción con el sector productivo y sindical. De hecho, existe; pero no de manera formal y articulada. Muchas veces son por circunstancias coyunturales, respondiendo a situaciones concretas y no con una mirada de planificación y estrategia que marque la dirección sobre la cual se quiere transitar.

- En 2014 se creó el Sistema de Diálogo y Consulta, a nivel del Ministerio de Relaciones Exteriores. Sin embargo, desde diciembre de 2019 no se registra actividad 
alguna. También se considera insuficiente el intercambio con la academia. Existen diversas cátedras de Relaciones Internacionales en las principales universidades del Uruguay, pero, a nivel formal no se registran interacciones suficientes. Una vez más, figura aquí el elemento de cercanía y conocimiento de personas que desempeñan estas tareas que sustituyen los procedimientos formales.

- Por eso, siguiendo la taxonomía de Bouzas, concluimos que esta área, el grado de involucramiento de actores no estales en la formulación e implementación de la política comercial externa, responde a un "club adaptado".

Bouzas refiere en su modelo también al diagnóstico de recursos y capacidades, y a las fortalezas y debilidades del modelo de gestión de organización institucional y de gestión de la política comercial externa. Los diseños institucionales no son solo las descripciones de competencias, identificación de los actores involucrados y mecanismos de coordinación, participación y articulación. También, señala Bouzas, implica conocer los recursos disponibles y las capacidades que se tienen para poder moldear la política comercial externa. Nosotros no hemos puesto el foco en esta área; sin embargo, mediante un pedido de información pública al Ministerio de Relaciones Exteriores (ver Anexo) y en las numerosas entrevistas realizadas fueron surgiendo algunos elementos que nos parece oportuno reflejar en este momento. No nos atrevemos a señalar que sean conclusiones categóricas, pero sí indicativas del reflejo de la estructura institucional vigente.

A. Recursos y capacidades de los arreglos institucionales en la Política Comercial Externa

- Capacidad organizacional entendida como "la habilidad para promover la convocatoria, el diálogo y la persuasión, trayendo a la mesa a los jugadores relevantes y persuadiéndolos para trabajar en la dirección de los objetivos compartidos...la capacidad de convertirse en puntos focales creíbles y eficaces, lo que dependerá, entre otras cosas, de su habilidad para convocar a actores públicos y privados relevantes, de la credibilidad de sus iniciativas y programas, y de su capacidad para formular y diseminar estudios técnicos que avalen sus iniciativas y de la disponibilidad de recursos humanos competentes y calificados." (Bouzas, 2020, pp.16-17)

En base a lo observado:

- Tanto el Ministerio de Relaciones Exteriores como el Ministerio de Economía y Finanzas son reconocidos como agencias líderes con competencias definidas. Por su trayectoria reciente, y de larga data, cuentan con credibilidad y poder de convocatoria. Sin embargo, es menester dejar en claro que en los primeros 15 meses de esta administración de gobierno (mayo 2021) el MRREE, quien preside y debe convocar a la CIACEX, no lo ha hecho. De acuerdo con el Plan Estratégico de Política Exterior 2020-2025 presentado por el Ministerio de Relaciones Exteriores, al 31 de diciembre de 2020 se debería haber aprobado un Decreto que actualice la integración y funcionamiento de la CIACEX en materia económica-comercial (punto 2.8.2). Tampoco se ha reactivado el sistema de Diálogo y Consulta.

- En cuanto a Uruguay XXI, su rol como agencia de promoción de exportaciones y atracción de inversiones es reconocido tanto por actores públicos como privados. Se destaca la capacidad, experiencia e idoneidad de los recursos humanos. 
- Capacidades técnicas "supone la capacidad de formular diagnósticos prospectivos y planes estratégicos, evaluar el resultado de las políticas y ajustarlas oportunamente, comprender las implicaciones de las materias sujetas a negociación internacional y poder identificar intereses, costos y beneficios, vincular esos intereses y los instrumentos de política comercial con las políticas de desarrollo productivo y establecer una dinámica de aprendizaje institucional." (Bouzas, 2020, p.17).

En base a lo observado:

- La Asesoría de Política Comercial del Ministerio de Economía y Finanzas cuenta con un número adecuado de funcionarios a nivel técnico que permanecen en funciones más allá de los cambios de gobierno. En efecto, el Director -Juan Labraga- ocupa la dirección desde octubre de 2016 (previamente, desde 2005 se había desempeñado como Asesor de la Política Comercial).

- Las dificultades mayores se observan en el Ministerio de Relaciones Exteriores:

- Elevada rotación a nivel de Direcciones Generales;

- Brazo comercial del Ministerio fragmentado;

- Inactividad de la Unidad de Análisis Estratégico.

- Necesidad de formación permanente y especializada en temas comerciales.

- Tensión entre modelos de una cancillería con un perfil multidisciplinar y una que tienda a la especialización por áreas temáticas en sus funcionarios. Los pocos recursos humanos imposibilitan esto último.

- Por fuera del eje MRREE-MEF y, mitigando las dificultades encontradas a nivel del MRREE, los demás actores gubernamentales involucrados en la PCE siguen un patrón semejante al de la APC, contando con conocimientos especializados y continuidad en el tiempo.

- Capacidades políticas representan la habilidad para:

"conseguir el apoyo político necesario para alcanzar los objetivos propuestos y proteger el proceso de política de la captura; así como de acceder, involucrar, influir y asegurar el apoyo de las autoridades pertinentes para posibilitar un mandato estable, el entorno institucional apto para hacerlo y el apoyo institucional para abandonar, sobre bases puramente técnicas, aquellas iniciativas que fracasan en su implementación." (Bouzas, 2020, p.18)

En base a lo observado:

Como señalamos, la fragmentación en la autoridad líder-competencia modularentre el MRREE y el MEF genera que las capacidades políticas se vean sujetas a los liderazgos, pesos políticos, capacidad de articulación entre los ministros y grado de alineamiento con el Presidente de la República. En ese sentido, desde 2005 a la fecha, podemos observar diversos episodios donde esto se refleja con claridad. Un ejemplo podría ser cuando Uruguay discutió la posibilidad de la firma de un Tratado de Libre Comercio con Estados Unidos. 
- Capacidades presupuestarias es un indicador predominante cuantitativo que condiciona fuertemente las otras capacidades (Bouzas, 2020, p18).

En base a lo observado:

- Por el alcance de esta investigación, no estamos en condiciones de señalar si los recursos presupuestarios son adecuados o no. Sí sabemos que son recursos limitados y que es un área -sobre todo Cancillería- que no es priorizada a la hora de asignar recursos. Se nos ha señalado, en más de una oportunidad, el hecho de que han aumentado la cantidad y complejidad de eje temáticos en las relaciones internacionales y ha habido poca modificación en el número de recursos humanos.

- Asuntos presupuestarios han sido identificados por varios entrevistados como limitante, por ejemplo, a la hora de pensar en que funcionarios de carrera permanezcan por un período mayor a dos años en el Uruguay en tareas de Dirección General.

B. Fortalezas y debilidades de los arreglos institucionales de la política comercial externa.

Bouzas presenta el diagnóstico de las fortalezas y debilidades de la PCE siguiendo el modelo propuesto por Stein \& Tommasi (2006), que se basa en seis atributos: i) estabilidad de la política; ii) grado de adaptabilidad/flexibilidad; iii) cuán coherente y coordinada es su implementación; iv) calidad y grado de implementación de las decesiones; v) orientación de la política al interés público; vi) eficiencia en el uso de los recursos.

No contamos con elementos cuantitativos para dar respuesta a estos puntos porque no fueron parte del objeto de investigación. A título meramente cualitativo, y abordando algunos de los puntos mencionados, podemos identificar que la PCE del Uruguay: ha contado con estabilidad de larga trayectoria, reconocido tanto a nivel local como internacional; no ha contado con la adaptabilidad-flexibilidad necesaria para acoplarse a tendencias internacionales, limitada por el "corset" que ha significado el Mercosur; y cuenta con instancias formales de coordinación (más allá de su actual desuso) creadas a modo llevar adelante una política coherente y eficiente.

\section{Preguntas específicas de investigación}

Como acabamos de señalar en el apartado anterior, Uruguay cuenta con una estructura institucional para hacer frente a su estrategia de inserción económico-comercial. Sin embargo, en nuestro análisis no solo alcanzaba con saber si existía y cuál era el diseño institucional creado. Partiendo de una hipótesis inicial que nos llevó a formular que era necesario una modernización de la arquitectura institucional, nos preguntamos si la vigente estructura se adapta a los desafíos que el mundo actual le exige hoy a Uruguay.

Luego del proceso de investigación, concluimos que no podemos responder $100 \%$ afirmativamente ni 100\% negativamente a esta segunda pregunta de investigación. En efecto, la mejor respuesta que podemos dar es que la estructura institucional vigente se adapta a la realidad actual del Uruguay en materia de política comercial externa; pero no es adecuada para dar respuesta a los desafíos que hoy plantea el mundo, requiriendo de 
Uruguay la necesidad de tomar decisiones clave y estratégicas si pretende hacer frente a los mismos.

Cuando hace más de un año, al plantear en el programa analítico de tesis la identificación del tema, señalábamos que el futuro del Uruguay está inequívocamente vinculado a cómo logre insertarse en el mundo y que el comercio internacional es un elemento trascendental para el crecimiento económico de un país como Uruguay. Así ha quedado de manifiesto a lo largo de este trabajo, particularmente al haber realizado un breve repaso por lo que ha sido la historia de la Nación en esta materia. Se percibe cierta falta de confianza y optimismo sobre el destino como país, siendo estas bases necesarias para el progreso. Por lo tanto, prepararse para afrontar los nuevos desafíos que se presentan y construir un proyecto propio, resulta algo no solo pertinente, sino de enorme responsabilidad.

\subsection{Recomendaciones}

En virtud de que la pregunta dos no tiene una respuesta contundente afirmativa, en esta sección quisiéramos responder la tercera pregunta planteada - ¿cuáles deberían ser los pilares centrales sobre los cuales diseñar estratégicamente dicha estructura? ofreciendo algunas recomendaciones que entendemos clave a la hora de modernizar el diseño institucional. Lo hacemos desde una mirada global de la política comercial externa como política pública.

A. Distribución de competencias entre los distintos poderes del Estado

- Diálogo entre el Poder Ejecutivo y el Poder Legislativo

Las atribuciones de los distintos poderes del Estado se encuentran consagradas en la Constitución de la República, lo que asegura el principio de separación de poderes. Sin ánimo alguno de violentar esto, recomendamos la institucionalización de un diálogo formal periódico (semestral) entre el Ministerio de Relaciones Exteriores y los partidos políticos con representación parlamentaria.

El objetivo de estos encuentros debe ser la creación de un espacio -distinto a los mecanismos que tiene el Poder Legislativo para convocar a un Ministro a una comisión o a la respectiva Cámara- que permita una conversación abierta para explicar e intercambiar visiones sobre puntos específicos de la política comercial externa. No se trata de un espacio meramente informativo, sino abierto a la posibilidad de recibir aportes que favorezcan la construcción de la política. Hasta el momento el diálogo ha sido más bien reactivo, ocasionado por acontecimientos específicos. Creemos que hace falta una instancia proactiva y propositiva. No es este el momento de avanzar en un máximo grado de detalle, pero estas reuniones deberían tener una agenda de reunión conocida en forma previa por aquellos que integran la convocatoria.

- Estudios de impacto

Tomando en consideración una práctica utilizada en Nueva Zelanda, recomendamos que los acuerdos comerciales que lleguen al Parlamento Nacional para ser aprobados deban ser acompañados de un Análisis de Interés Nacional (AIN), es 
decir un estudio que detalle el potencial impacto que tendría el acuerdo para los distintos sectores de la economía nacional tratados. Contar con estos análisis, por un lado, obligará al Poder Ejecutivo a negociar buscando defender los intereses nacionales obteniendo el mayor beneficio posible, dando lo menos que se pueda. Pero también permitirá tener identificados los puntos fuertes y sensibles para tener en cuenta. Contar con estos estudios, ayudará al Poder Legislativo a tener una base sólida a la hora de votar.

Los análisis de impacto son un elemento trascendental del proceso de ratificación de un tratado y deberían ser un paso en sí del proceso de negociaciones y no una consecuencia de estas. Mirando el pasado reciente, para el caso de la actualización del tratado con Chile no hubo un análisis de impacto hasta después de su presentación ante el Poder Legislativo. Pensando en un futuro, con una política comercial externa con mayor proactividad y dinamismo, mandatar la presentación de un informe de este tipo será una señal de seriedad y transparencia.

B. Distribución de competencias a la interna del Poder Ejecutivo

- Liderazgo

Tanto a partir de la literatura existente como las entrevistas realizadas durante el proceso de estudio, se confirma la existencia de un liderazgo netamente compartido entre el Ministerio de Relaciones Exteriores y el Ministerio de Economía y Finanzas respecto a la política comercial externa. Esta característica de liderazgo compartido, en sí, no es un hecho negativo, siempre y cuando exista articulación entre las autoridades y coherencia en las decisiones realizadas. En este sentido, entendemos perjudicial para los intereses nacionales que uno $\mathrm{u}$ otro ministerio ejerza mayor liderazgo dependiendo del ministro de turno. Por consiguiente, creemos fundamental que estas carteras deben ser integradas por un ministro político, idóneo en la materia, capaz de trabajar en equipo y coordinación entre sí y que tengan la confianza directa del presidente de la República. Más adelante, al abordar la reactivación de la CIACEX propondremos una solución a este liderazgo fragmentado.

- Área comercial del Ministerio de Relaciones Exteriores del Uruguay

Por las características de la inserción económica comercial de nuestro país, entendemos que es necesario unificar las áreas comerciales del Ministerio de Relaciones Exteriores, con un diseño más claro y bajo una única autoridad que le dé una mirada integral a este brazo de la política exterior cada vez más multidimensional y complejo. La Dirección de Asuntos Económicos Internacionales y la Dirección General de Integración y Mercosur, son caras de una misma moneda. Más allá de la posibilidad de coordinación que hoy puede existir, no siempre ha sido así. Durante la investigación, la tentación de mirar el modelo chileno de la Subsecretaría de Relaciones Económicas Internacionales está siempre presente, incluso en los entrevistados. Sin embargo, como tal, no es posible de ser aplicado hoy en el Uruguay por la limitante constitucional. Nuestra Constitución prevé la existencia de un solo Subsecretario (o viceministro) por cada cartera. Lo que no es una limitante -solo requiere voluntad política y técnica-, es la posibilidad de llevar adelante una reorganización y tratar de unir la fragmentación existente. No 
se trata de unir las dos direcciones, bajo una sola autoridad, sino de repensar el área en su conjunto.

A lo largo de la investigación hemos sido capaces de comprobar el deseo y la necesidad de lograr una resolución a este problema; pero también la advertencia de que es un tema sensible, que le ha costado a la Cancillería tratarlo porque ataca "chacras internas". En ese sentido, la primera recomendación que hacemos es pensar más allá de las personas para no limitar los avances posibles. Hay que analizar cuál es el arreglo institucional que le sirve al Uruguay para defender mejor sus intereses.

En segundo lugar, queremos ensayar una propuesta tentativa y general con algunos lineamientos sobre cómo entendemos se podría realizar la estructura.

- Ministro de Relaciones Exteriores: ministro político idóneo en la materia, de confianza del Presidente.

- Subsecretario de Relaciones Exteriores: recomendamos un perfil político o diplomático de carrera, pero con sensibilidad hacia los asuntos económicocomerciales.

- Dirección General del Ministerio de Relaciones Exteriores con un perfil capaz de articular, dialogar y capaz de ofrecer una mirada que integre el conjunto de la Cancillería.

- Dirección General de Relaciones Económicas Internacionales: esta sería la dirección que uniera todo el brazo comercial de la Cancillería. Esta dirección debe ser ocupada por una persona capaz, idónea en los temas económicocomerciales, con mirada global e integral. Sería sano que la Cancillería pudiese reconocer si hoy tiene entre sus funcionarios personal con este perfil. De no tenerlo, se recomienda iniciar un proceso de formación interno. Temporalmente, se sugiere poder ampliar la búsqueda más allá de Cancillería y realizar una designación política para esta posición. Para brindar continuidad a la política comercial externa, este cargo debería tener la menor rotación posible a lo largo de un período de gobierno. Implicará una erogación mayor a la común para funcionaros en Montevideo.

Esta Dirección General, creemos que podría tener una organización semejante a esta propuesta.

- Dirección de Asuntos Económicos Bilaterales:

- División América del Sur.

- División América del Norte, Central y Caribe.

- División Europa.

- División Asia y Oceanía.

- División África, Medio Oriente. 
Temas transversales a todas estas divisiones que podrían requerir de un departamento específico:

- Departamento de Acceso a Mercados

- Departamento de Aspectos Regulatorios del Comercio

- Departamento Cadenas Globales de Valor

- Departamento Implementación y Difusión de Acuerdos Comerciales (en conjunto con Uruguay XXI)

- Dirección de Asuntos Económicos Regionales y Multilaterales:

- División Mercosur

- División ALADI

- División OMC

- División Seguimiento Procesos de Integración (Ej. Alianza del Pacífico, ASEAN, Unión Europea)

Temas transversales a todas estas divisiones que podrían requerir de un departamento específico:

- Departamento de Propiedad Intelectual

- Departamento de Comercio y Desarrollo sustentable

- Departamento de Servicios, Inversiones y Economía Digital.

- Departamento de Solución de Controversias

- Dirección de Inteligencia y Promoción Comercial e Inversiones

- Departamento de Información Comercial (en conexión con Uruguay XXI para temas de promoción, inversión y análisis de mercado, aprovechando la estructura, experiencia y capacitación del staff de Uruguay XXI. No quitarle el estatus jurídico a Uruguay XXI, sino trabajar en conjunto)

- Departamento de Análisis de Datos

- Otras áreas para tener en cuenta:

- Unidad de Participación ciudadana

- Unidad de Comunicación y transparencia

- Unidad de Planificación, Acción y Evaluación 
Ilustración 2 - Propuesta de estructura de la institucionalidad del brazo comercial del Ministerio de Relaciones Exteriores del Uruguay (elaboración propia)

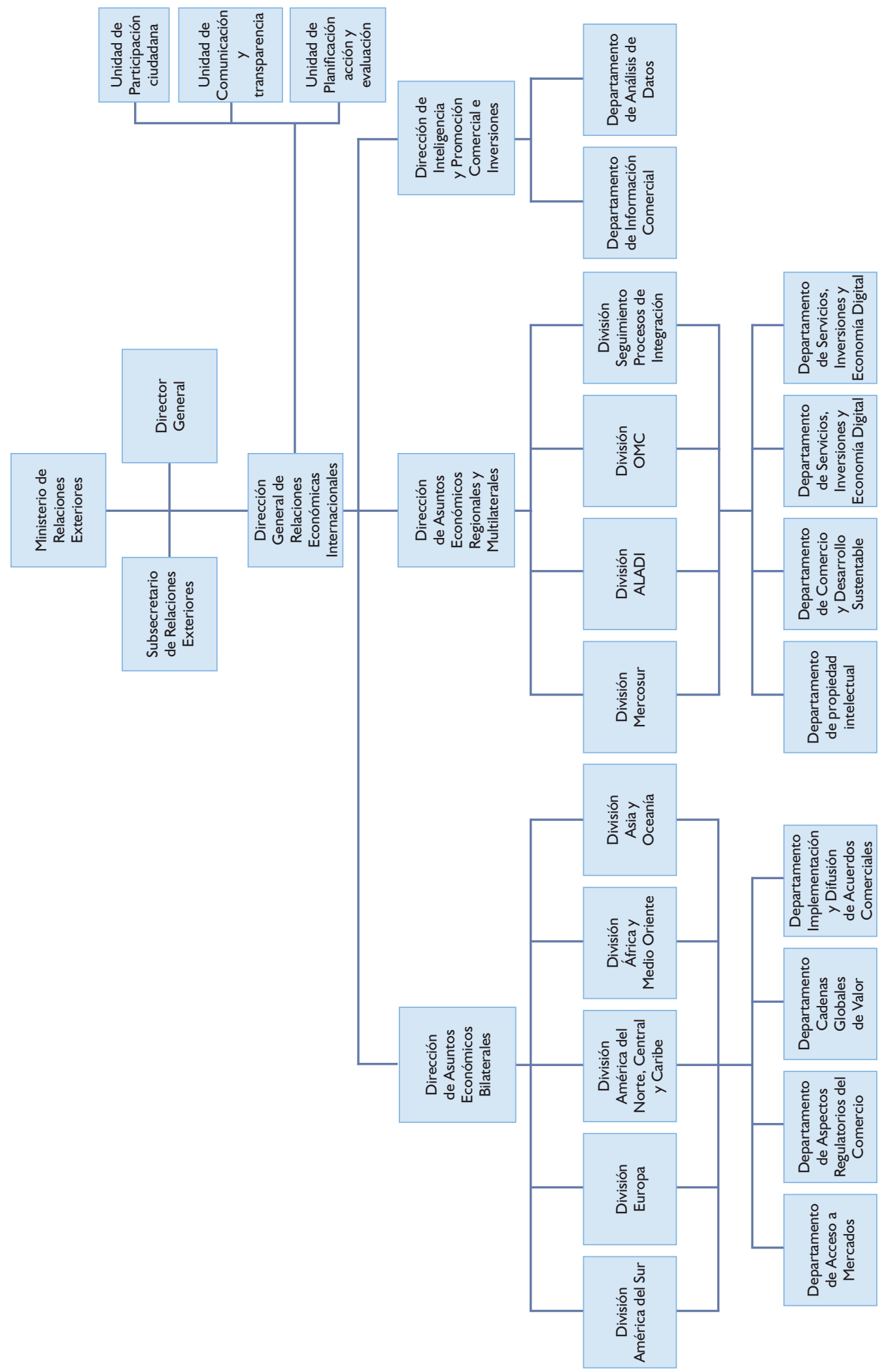


- Mecanismo "Desk Officers".

A partir de algunas conversaciones que tuvimos, recomendamos realizar un plan piloto de trabajo bajo el mecanismo "Desk Officers". Es decir, seleccionar 5 países que para Uruguay hoy sean relevantes desde una mirada integral: política, económica-comercia, de cooperación, consular, cultural. Seguramente cada país tendrá un énfasis distinto, pero lo que se pretende con este mecanismo que es un grupo de funcionarios este focalizado en un único país y cobra todos los ángulos de la relación de Uruguay con ese país. Jerarquizará el país-mercado y a su vez permitirá a Uruguay tener una visión integral de la relación bilateral.

- Rotación de funcionarios

Un asunto levantado en varias entrevistas fue la rotación constante en la que están involucrados los funcionarios del servicio exterior, alternando períodos de cinco años en el exterior con dos años en Uruguay. En la medida de que exista una memoria institucional, léase constancias de reuniones, actas de instancias de coordinación, manuales de procedimiento, y descripciones de cargo actualizadas, esto no debería presentar un problema; sin embargo, observamos que, nuevamente amparándose en la escala del país, la informalidad en los procedimientos, junto con la falta de una estrategia consensuada con un plan de acción definido, afecta el seguimiento de temas a lo largo de un período determinado, y, sobre todo, al momento de traspasar responsabilidades entre funcionarios.

Contar con estructuras sólidas, que ofrezcan la posibilidad de desarrollar ejes estratégicos en una línea de continuidad (de acuerdo con el Plan Estratégico base), hará que la rotación sea vista desde una perspectiva positiva (y no como un problema, como se visualiza hoy), es decir, buscando sacar ventaja de los conocimientos y experiencias que traer el funcionario que estuvo cinco años en el exterior y viene dos años a trabajar a Uruguay. Ese aprendizaje que trae puede ser volcado en la estructura.

- Formación de funcionarios

Otro asunto vinculado a la rotación de los funcionarios hace referencia a los ejes temáticos de la Cancillería. Es decir, funcionarios que en un período trabajan en el área consular, pero al regresar al país -luego de su pasaje por el exteriorson designados a trabar en el área económica o de cooperación, por ejemplo. El presupuesto con el que cuenta el Ministerio de Relaciones Exteriores, alejado del presupuesto de su homónimo en Nueva Zelanda o Chile, lleva a que los funcionarios no puedan desarrollar avances en las especializaciones temáticas.

Recomendaos la creación de un plan de formación con una mirada a largo plazo que permita iniciar un período de transición-transformación para lograr un mejor aprovechamiento de los recursos humanos. El Instituto Artigas del Servicio Exterior debería trabajar en estrecha vinculación con las diversas cátedras de Relaciones Internacionales, Comercio Internacional, Derecho Internacional. Asimismo, sería beneficioso aprovechar el conocimiento y la experiencia existente en las áreas de comercio exterior de las distintas Cámaras sectoriales o bilaterales. Estas interacciones permitirían crear una formación con una base común para luego 
desarrollar canales de especialización que permitan conjugar elementos teóricos con la práctica que da la experiencia. Uno de esos ejes debería ser la formación en negociación, particularmente, con un énfasis en negociación comercial. Esto permitirá generar cuadros interinstitucionales de negociadores (MRREE, MEF, MGAP, MIEM, por citar las áreas más sensibles de la política comercial externa).

Por otra parte, la formación permitirá fortalecer la capacidad de los equipos del Servicio Exterior y dotar a las misiones diplomáticas con recursos humanos que puedan responder más fielmente a los objetivos que el Uruguay persigue en cada uno de los destinos. Con esto se pretende lograr acompañar y enfrentar los múltiples desafíos que hoy tiene Uruguay: hay más temas que deben ser abordados y requieren de un enfoque profesional, más demandas a las cuales deben hacer frente el personal diplomático y más retos globas que, como Cancillería, requieren darle seguimiento.

- Análisis Estratégico

Contar con un Ministerio de Relaciones Exteriores que sea capaz de generar y mantener activo un espacio de análisis, reflexión y consulta permanente se ha convertido en una necesidad para un país como Uruguay. En línea con lo establecido en el Plan Estratégico en el inciso 3.1, en el entendido de que la Unidad de Análisis Estratégico ya existe en la órbita de Cancillería, recomendamos fervientemente su reactivación para analizar, desde un punto de vista geopolítico y económicocomercial, la realidad internacional, visualizando las oportunidades y amenazas que podemos tener en determinados mercados o regiones.

A nuestro entender, esta Unidad de Análisis Estratégico, debería trabajar, en primer término, en tres áreas prioritarias:

- La creación de un Mapa de Mercados que identifica países o regiones con las que se quiere negociar. Categorizarlos por nivel de complementariedad (muchamedia-baja) y estudiar los acuerdos comerciales que esos países o regiones ya han firmado. Una posible línea de análisis que sugerimos es: conocer las concesiones que ese mercado dio para los productos que son de nuestro interés exportar; prestar atención a las condiciones que exigió para los productos que son de su interés y tienen sensibilidad en Uruguay; identificar cuál fue la posición respecto a temas como propiedad intelectual, subsidios.

- Una segunda área de trabajo, una vez creado el Mapa de Mercados, es la definición de prioridades y definir la estrategia a seguir para cada uno de esos países o regiones. Para esto, tener en cuenta la cantidad de recursos disponibles, los pasos que son necesario dar y los plazos que pueden requerir. Por ejemplo, en materia carnes, una estrategia a seguir para la apertura de mercados es la priorización de aquellos donde el precio de importación es más alto y la brecha arancelaria no es un obstáculo (Ejemplo: Indonesia, Filipinas o Vietnam). Para el caso de la búsqueda de acuerdos comerciales, se debería tener en cuenta, además, la habilitación sanitaria, el vínculo comercial y un arancel que no sea un impedimento. 
- Es importante la comparación arancelaria que pagan los exportadores que abastecen tal mercado y los que paga (pagaría) Uruguay por exportar a ese mercado.

- Finalmente, una tercera tarea prioritaria, es la creación de un manual de práctica con criterios comunes para que todo departamento comercial de una representación diplomática uruguaya en misión en el exterior pueda llevar adelante. El objetivo es poder tener un modo de proceder común, conocido por quienes desempañan las tareas comerciales que permita el seguimiento.

Sabemos que el tema recursos humanos es escaso y que las tareas de pensamiento estratégico y planificación no suelen ser las prioritarias. Sin embargo, estamos convencidos de su importancia y necesidad. Hemos notado, además, que existen varios diplomáticos que una vez se jubilan, siguen activos enseñando en universidades $\mathrm{o}$, incluso a veces, en el IASE. Proponemos que esta Unidad, sea integrada por 4 Embajadores (Senior Ambassadors) que haya tenido al menos 2 destinos como Jefe de Misión, que tengan distintas experiencias y perfiles. Además, debería ser integrado por 3 Embajadores (Senior Ambassadors) en actividad, el Director General del Ministerio de Relaciones Exteriores y el Director General de Relaciones Económicas Internacionales (de acuerdo al nombre propuesto en este trabajo el director del brazo comercial).

C. Agencias públicas subsidiarias que participan en el espacio de la política comercial externa. Modalidad predominante de coordinación-interacción

- Reactivación de la CIACEX

Desde un punto de vista normativo, y en base a lo investigado, existen pocas objeciones respecto a la normativa existente en torno a la CIACEX y su Secretaría Ejecutiva. Tanto las estipulaciones en cuanto a sus reuniones mensuales a nivel de ministros, como la instancia técnica que la debe preceder, se tratan de espacios fundamentales para la generación de consensos en materia de inserción internacional, negociaciones comerciales, promoción comercial y, atracción de inversiones. Sin embargo, si esta institucionalidad no es aprovechada, de nada sirve.

Al cierre de esta investigación, nos encontramos ante una CIACEX que, en 15 meses de gobierno, aún no ha sido convocada y que su Secretario Ejecutivo no ha sido designado; es más, desde el 2015 este cargo ha estado vacante por lo que el letargo de la comisión trasciende fronteras políticas. La no convocatoria de la CIACEX no implica que la política comercial externa esté en un punto muerto, pero sí lo está su abordaje desde una perspectiva multidimensional de máxima jerarquía gubernamental. Ha habido avances a nivel de articulación, pero siempre en instancias bilaterales o trilaterales entre ministros, enfocadas en aspectos sectoriales como la creación de Procarnes y Prolácteos, o vía canales informales como ya hemos mencionado anteriormente.

La CIACEX debería tratarse de un ámbito horizontal, eficiente, activo, fluido y empoderado, sobre todo si en el mediano y largo plazo se quiere contar con una PCE proactiva, dinámica y alineada a las exigencias del comercio del siglo XXI. 
Asimismo, es menester destacar que está estipulado que desde la CIACEX deben nacer los lineamientos quinquenales para Uruguay XXI, cosa que desde el cambio de gobierno no han sido aprobados ni comunicados.

En línea con el Plan Estratégico del MRREE, se coincide que la CIACEX debe reactivarse y actualizarse su integración (inciso 2.8.1). Respecto a su reactivación, entendemos que en este proceso es crucial el establecimiento de la frecuencia de reuniones -con agendas claras-, coordinación de grupos de trabajo, y establecimiento de ejes estratégicos con objetivos y metas a cumplir. Para ello, la Secretaría Ejecutiva debe cumplir un rol más protagónico, como articulador y facilitador de que esto ocurra.

Hasta el momento, la Secretaría Ejecutiva ha estado en la órbita del Ministerio de Relaciones Exteriores, siendo el secretario ejecutivo designado por el Poder Ejecutivo a instancias de la CIACEX. Recomendamos que, con el objetivo de jerarquizar tanto la CIACEX como su Secretaría -y por tanto a la política comercial externa-, ésta debería funcionar en la órbita de Presidencia de la República. Como ya hemos mencionado, en Uruguay el liderazgo de la PCE está fragmentado entre el MRREE y el MEF, siendo variable la relevancia de uno u otro ministerio dependiendo de quién está a cargo de estos. Al quitar la secretaría de este eje creemos que se posibilita un liderazgo de la PCE con mayor autonomía e independencia de las personas. Se le quita la potestad de convocatoria a los ministerios líderes y se busca garantizar periodicidad en el abordaje de la PCE. Sintéticamente, debe existir un "relanzamiento" de la CIACEX que permita reintroducir el espíritu del decreto de su creación en el funcionamiento efectivo de la misma.

En cuanto a su integración, para acercarnos a las tendencias mundiales, y reafirmando la existencia de múltiples dimensionas a la hora de abordar la política comercial externa, creemos pertinente incluir al recientemente creado Ministerio de Ambiente.

D. Modalidad de participación de los actores privados relevantes en el proceso de formulación e implementación de la política comercial externa, transparencia y mecanismos de consulta

- Articulación con el sector privado

En el análisis realizado sobre la estructura institucional no se detectaron instancias formales donde el sector privado, en un mismo lugar, pudiera plantear preocupaciones o necesidades a ser abordadas por parte del sector público. Lo que sí se identificaron fueron espacios como los Consejos de Dirección de Institutos sectoriales donde existe representación del sector productivo, pero se trata de instancias alejadas de los tomadores de decisiones por la existencia de distintas capas burocráticas.

Más allá de que los entrevistados han recalcado la escala de nuestro país como un facilitador de la cercanía entre públicos y privados, es de orden contar con un espacio formalmente establecido, con reuniones periódicas, donde el sector privado pueda exponer su visión acerca del rumbo de la política comercial externa y compartir la información que poseen (muchas veces mayor a la que tiene el 
sector público). Una CIACEX ampliada, con participación de privados y en el que tanto exportadores de bienes como de servicios puedan exponer su postura sería beneficioso para dirigirnos hacia una política comercial externa consensuada e inclusiva, capaz de ser sostenible en el tiempo. También concebimos dentro del sector privado al PIT-CNT. Por su peso, su aporte y contribución al momento de consensuar una PCE es importante.

Hasta la Ley de Presupuesto del gobierno actual, el Consejo de Dirección de Uruguay XXI poseía un formato semejante, con la integración de públicos y privados por igual, sin embargo, abordaba una instancia muy específica de la política comercial externa: la promoción comercial y la atracción de inversiones. Quedando por fuera una plétora de dimensiones.

A nuestro criterio, dos elementos importantes que debería desarrollar esta CIACEX ampliada, en sus primeras reuniones, es, por un lado, la definición de la oferta exportable del Uruguay. Es decir, conocer qué es lo que tenemos para ofrecer al mundo, con qué calidad y en qué cantidad; y cuáles son las posibilidades de ampliar esa oferta exportable en el futuro. Estos insumos deben ser tenidos en cuenta a la hora de desarrollar el mapa estratégico de mercados que expresamos anteriormente. Y, en segundo lugar, es importante que esta CIACEX ampliada, establezca un subgrupo de trabajo que se dedique al tema de la competitividad interna. Como vimos, la política comercial externa, también tiene un pie puesto en la economía nacional. No se trata solo de abrir mercados, sino de poder llegar a ellos de manera competitiva, de ahí la importancia por revisar también los primeros eslabones de la larga cadena.

- Articulación con la sociedad civil

A diferencia de la articulación con el sector privado, para la cual no existe instancia creada, para el diálogo entre el Ministerio de Relaciones Exteriores y la sociedad civil en general ya existe el Sistema de Diálogo y Consulta creado en el año 2014 y que funcionó hasta finales del 2019. Existe normativa, ámbitos de consulta previstos, $y$, sobre todo, periodicidad en por lo menos una de las modalidades de participación ciudadana: plenarios anuales.

Por la naturaleza compleja y demandante de discreción que tiene la política exterior, este tipo de ámbitos son cruciales para que la sociedad civil en general cuente con la posibilidad de acercar planteos, evacuar preocupaciones, y, sobre todo, como estipula su decreto creador "ejercer una supervisión responsable de la política exterior". Mirando el ejemplo de Nueva Zelanda, contando ya con un acervo importante de tratados de libre comercio, en el año 2018 comisionó la Trade for All Advisory Board, ya abordada, cuya finalidad era hacer más accesible e inclusiva la política comercial. Nueva Zelanda vio nítidamente las nacientes tendencias nacionalistas y anti-globalistas y tomó acción para evitar que éstas pudieran afectar lo logrado hasta el momento, así como buscar aprovechar la instancia para generar mayor confianza por parte de toda la población en cuanto a su política comercial externa. 
La ciudadanía debe tener la posibilidad de expresarse acerca de la política comercial externa. Debe poder hacerlo por escrito, de manera formal y sobre temas que son de dominio de esta política. Por ejemplo, el Ministerio de Relaciones Exteriores puede anunciar el inicio de conversaciones con determinado país y abrir un período ventana para recibir consultas, propuestas, inquietudes.

- Articulación con la academia

Habiendo presentado la necesidad por incorporar análisis de impacto a cualquier tratado comercial presentado ante el Poder Legislativo, una manera de aprovechar las distintas cátedras existentes en economía, comercio y relaciones internacionales es mediante la licitación de estos informes. Tercerizando la elaboración de estos uno fortalece su objetividad -al no ser confeccionado por actores involucrados en la negociación-, y a la vez, permite aprovechar y especializar recursos existentes en la academia.

Una segunda oportunidad de involucrar a universidades y académicos en general es fortaleciendo la interacción entre Universidades, Cámaras Empresariales y el Instituto Artigas del Servicio Exterior (IASE). A modo de ejemplo, vimos como la CUTI nos manifestó que ha estado trabajando con el IASE en la capacitación para lograr vender servicios tecnológicos. Recomendamos, además, que esta forma de trabajo no sea unidireccional, sino justamente sea una articulación. En tal sentido, puede resultar importante que las Cámaras Empresariales, los distintos Ministerios e incluso actores relevantes de la sociedad civil puedan verse beneficiados mediante el asesoramiento de diplomáticos experimentados. De la misma manera en que hoy, algunas cátedras de universidades son dictadas por diplomáticos con vocación académica, brindando su experiencia y conocimientos a los estudiantes, recomendamos que el IASE pueda nutrirse de académicos formados para fortalecer los recursos humanos que luego representarán al país en distintas misiones diplomáticas.

En línea con los incisos 2.7.1 y 2.7.3 del Plan Estratégico, debe procurarse aprovechar el conocimiento existente para elaborar las mejores y más actualizadas curriculas si nuestro país quiere acoplarse a las tendencias de negociaciones del siglo XXI.

\section{- Transparencia. Rendición de Cuentas}

Durante la investigación llamó la atención el profesionalismo, dedicación y grado de atención que Chile le asigna al tema de la transparencia y la rendición de cuentas públicas, en este caso en materia de política comercial externa. Somos conscientes de que hay un tema de recursos, pero solo basta con ingresar al sitio web de la Subsecretaría de Relaciones Económicas Internacionales y al del Ministerio de Relaciones Exteriores del Uruguay y notar la abismal diferencia. Creer que estos puntos no son importantes, es un error. La buena comunicación de los resultados que se obtienen es fundamental, no solo para mostrar logros a nivel gubernamental, sino también para hacerlos accesibles a la población en general y a quienes pueden verse directamente beneficiados.

Recomendamos, por lo tanto, que la CIACEX pueda realizar un Balance de Gestión Integral. Un documento anual con los principales resultados de su 
gestión. Es deseable que sea presentado de forma sencilla, visualmente agradable de leer y utilizando diversas estrategias de comunicación, un documento escrito acompañando un video, por ejemplo. La comunicación es un área que exige cada vez mayor profesionalismo, por lo que se recomienda contar con un equipo destinado a desarrollar estrategias en ese sentido.

\subsection{Reflexiones finales}

Un buen diseño institucional es muy importante para el éxito de una política comercial externa. No lo garantiza, pero lo hace viable. La cantidad de entrevistas realizadas nos hizo notar que es un tema difícil de manejar. Hablar de transformaciones a nivel público -aunque también privado- cuesta. Sin embargo, al menos a nivel de las entrevistas realizadas, notamos una inclinación sobre la necesidad que tenemos como país de realizarlas. Una sensación de estar discutiendo siempre los mismos temas genera un desgaste difícil de sostener en el tiempo.

Hay momentos en la vida de una persona, de una familia, de una empresa, de un país, que requiere movimientos de timón bruscos para dirigirse a nuevos rumbos. No se puede negar que esos movimientos traen coletazos, pero también nuevas oportunidades. Uruguay debe romper, en ciertos ámbitos, el complejo de país chico situado entre dos grandes. Eso no puede ser una excusa que lo condicione a pensar lo que quiere ser, recuperar soberanía comercial y definir su estrategia. Siempre puede ser un buen momento para generar esos cambios, pero quizá este tiempo sea aún más propicio.

Uruguay cuenta con recursos humanos capacitados, una oferta exportable de calidad demanda por el mundo y una tradición histórica -al menos hasta los primeros años del este siglo- de apertura al mundo, de "estar en el barrio, pero mirando al mundo". Lo que hoy estamos necesitando es dar un paso más y respaldar todo esto con un Ministerio de Relaciones Exteriores del siglo XXI. Un Ministerio con estructuras claras, sólidas, pero modernas, flexibles y eficientes. La construcción y propagación de mitos no ayuda. El papel de la diplomacia orientada a promover el crecimiento y el bienestar del país debe fortalecerse y, a la vez, trabajar con una actitud de equipo, coordinando constantemente para generar los consensos necesarios, alineando a todos los actores involucrados hacia la concreción de los objetivos comunes. Se necesita pasar a una lógica del "nosotros" y dejar de pensar tanto en el "yo".

La importancia de la construcción de equipos sólidos ha sido una de las grandes enseñanzas de esta investigación. No se logran de un momento a otro, requiere perseverancia, esfuerzo, superar obstáculos. "Las personas ganan partidos, los equipos ganan campeonatos" (Gonzalo Noya)

Presentar una propuesta de transformación o una nueva política pública debe basarse en la cuádruple idea que requiere. Debe ser: políticamente viable, socialmente aceptada, legalmente aplicable, y técnicamente eficiente (Luis Aguiar). Nosotros agregamos audaz, creativa y que nos mueva del status quo. Al presentar nuestras recomendaciones no queremos pecar de ingenuos o voluntaristas. Ciertamente, no tenemos limitantes más allá del rigor académico, pero nos interesaba dejar claro que construir alternativas es posible. Quizá sea tiempo de creer más en nosotros mismos. 
“Los países no pueden ser mejores que su gente.

Cuando un país decae es porque su gente decae, cuando un país mejora es cuando su gente mejora.

Me refiero a personas que poseen actitudes que favorecen a que las cosas salgan bien y constantemente intentan mejorar y aprender."

Enrique Baliño

\section{Referencias bibliográficas}

Aguilar, J.L. (2012) Política Pública. Una visión panorámica. Programa de las Naciones Unidas para el Desarrollo en Bolivia (PNUD-Bolivia). Último acceso el 15 de mayo de 2021: https://www.bo.undp.org/content/bolivia/es/home/library/democratic_governance/politica-publica--una-vision-panoramica.html

Albertoni, N. (2019). Uruguay como solución. Su inserción internacional: cuando lo importante se transforma en urgente. Penguin Random House Grupo Editorial.

Álvarez, J., Bértola, L. (2010), «So similar, so different: New Zealand and Uruguay in the world economy», en C. Lloyd, M. Jacob, R. Sutch (eds.), Settler Economies in World History, Leiden, Brill Publishers. Series on Global Economic History.

Arteaga, J.J. (2018). Historia Contemporánea del Uruguay. Ediciones Cruz del Sur.

Bartesaghi, I (2020). Los desafíos del Mercosur en un nuevo contexto internacional. El Observador. http://acadeco.com.uy/files/2020_elobservador_desafios_mercosur_Bartesaghi.pdf

BID - INTAL. 2020. Informe Mercosul 2020: sob a presao da agenda externa. https:/ / downloadapi.paperflite.com/api/2.0/shared_url/5fce6b69b7444125162dc45e/ asset/5fce6b69b7444125162dc45d/download

Bitar, S. (2016). Las tendencias mundiales y el futuro de América Latina. Naciones Unidas. CEPAL https://www.cepal.org/es/publicaciones/40788-tendencias-mundiales-futuro-america-latina-edicion-2016

Borchet, I. Magntorn, J. (2018). What can the UK learn from existing customs unions? UK Trade Policy Observatory. https://blogs.sussex.ac.uk/uktpo/2018/03/29/whatcan-the-uk-learn-from-existing-customs-unions /

Bouzas, R. (2020) Evaluación Institucional de la Politica Comercial Externa. Banco Interamericano de Desarrollo. Instituto para la Integración de América Latina y el Caribe (INTAL). Sector de Integración y Comercio. Nota Técnica N'IDB-TN-2014. Septiembre 2020. https: / / conexionintal.iadb.org/2020/11/04/evaluacion-institucional-dela-politica-comercial-externa/

CEPAL -Comisión Económica para América Latina y el Caribe- (1994). El regionalismo abierto en América Latina y el Caribe: La integración económica al servicio de la transformación productiva con equidad. Naciones Unidas 1994. https://www. 
cepal.org/es/publicaciones/2140-regionalismo-abierto-america-latina-caribe-laintegracion-economica-al-servicio

Clemente, I. (2005). Politica Exterior de Uruguay, 1830-1985. Tendencias, problemas, actores y agenda. Unidad Multidisciplinaria - Programa de Población. Facultad de Ciencias Sociales. Documentos de Trabajo Nº69.

Cohen, S., Blecker, R. \& Whitney, P. (2003). Fundamentals of US Foreign Trade Policy: Economics, Politics, Laws, and Issues (2nd Edition) Boulder: Westview Press.

Díaz, R. (2003) Historia Económica de Uruguay. Edición actualizada a 2018. Montevideo: Fundación de Cultura.

EN PERSPECTIVA. Tratado de Libre Comercio Uruguay-México: ¿Qué cambios habrá en el acuerdo tras la visita del presidente Vázquez? - Entrevista a Pablo Rosselli. https://www.enperspectiva.net/deloitte/tratado-de-libre-comercio-uruguaymexico-que-cambios-habra-en-el-acuerdo-tras-la-visita-del-presidente-vazquez/

Ehrlich, S. (2007). Access to Protection: Domestic Institutions and Trade Policy in Democracies. https://www.cambridge.org/core/journals/international-organization/ article/abs/access-to-protection-domestic-institutions-and-trade-policy-in-democracies/B4DA7F1C290B7C74220C67D49F218D55

Fernández Luzuriaga, W. (1998) Los inicios de la política exterior en la actual administración. Unidad Multidisciplinaria. Programa de Población. Facultad de Ciencias Sociales. Serie Documentos de Trabajo No37.

Fernández Luzuriaga, W. y Ferro Clérico, L. (2004) La agenda de la política exterior uruguaya 1985-2000. Una visión académica. Unidad Multidisciplinaria. Programa de Estudios Internacionales. Facultad de Ciencias Sociales. Serie Documentos de Trabajo $\mathrm{N}^{\circ} 64$.

Fernández Reyes, J. (2013). Curso de Derecho de la Integración. Tomo I. Montevideo: Universidad de Montevideo.

Garzón, J. y Prieto, G. (2017). Estrategias de inserción económica internacional de Colombia y Brasil: regionalismo cruzado y estrategia de tamaño. https:/ / www.researchgate.net/ publication/324992244_Estrategias_de_insercion_economica_internacional_de_ Colombia_y_Brasil_regionalismo_cruzado_y_estrategia_de_tamano

González Parias C. (2019). La diplomacia digital: factor de cambio en la diplomacia tradicional. Institución Universitaria Esumer. Editorial Revista Mercatc 55.

Grugel, J. y Hout, W. (1999). Regions, regionalism and the South. En J. Grugel y W. Hout (eds.), Regionalism across the North-South divide: State strategies and globalization (pp. 3-13). Londres y Nueva York: Routledge.

Herrera, L.A. (1912) El Uruguay Internacional. Ediciones Cruz del Sur. Instituto Manuel Oribe

Jordana, J. y Ramió, C. (2002). Diseños Institucionales y Gestión de la Política Comercial Externa en América Latina. Banco Interamericano de Desarrollo. INTAL. ITD. STA. Documento de Divulgación 15. https://publications.iadb.org/publications/ 
spanish/document/Dise \%C3\%B1os-institucionales-y-gesti\%C3\%B3n-de-lapol\%C3\%ADtica-comercial-exterior-en-Am\%C3\%A9rica-Latina.pdf

Labraga, J (2014). Reflexiones sobre la Inserción Internacional de Uruguay. Letras Internacionales, Segunda Época, Año 8, N 181 y N 182, Revista Digital del Departamento de Estudios Internacionales de la Universidad ORT. https:/ / revistas.ort.edu.uy/letrasinternacionales

Manfredi, J.L. (2014). Taxonomía de la diplomacia digital en la agenda de las nuevas relaciones internacionales. Historia y Comunicación Social, 341-354. Visto en: https:/ / dialnet.unirioja.es/servlet/articulo?codigo $=4935938$

Mansfield, E. D., Milner, H. V., \& Pevehouse, J. C. (2007). Vetoing Co-operation: The Impact of Veto Players on Preferential Trading Arrangements. British Journal of Political Science, 37(3), 403-432. https:/ / doi.org/10.1017/S0007123407000221

Ministerio de Relaciones Exteriores de Chile. Subsecretaría de Relaciones Económicas Internacionales. https://minrel.gob.cl/minrel/ministerio/subsecretario-de-relaciones-economicas-internacionales

Ministerio de Economía y Finanzas (2019). Asesoría de Política Comercial. Acuerdo Mercosur-Unión Europea. http://apc.mef.gub.uy/innovaportal/file/27369/1/ acuerdo-mercosur---ue-28-de-agosto.pdf

Ministerio de Relaciones Exteriores del Uruguay (2020). El retiro de Argentina de las negociaciones comerciales del MERCOSUR no afectara acuerdos concluidos ni agenda 2020. https://www.gub.uy/ministerio-relaciones-exteriores/comunicacion/noticias/retiro-argentina-negociaciones-comerciales-del-mercosur-afectaraacuerdos

- (2021) Plan Estratégico de Política Exterior 2020-2025. https:/ /www.gub.uy/ministerio-relaciones-exteriores/institucional/plan-estrategico

MINISTERIO de Relaciones Exteriores del Paraguay (2020). Mercosur: Argentina informó que dejará de participar de las negociaciones externas en curso. https://www. mre.gov.py/index.php/noticias-de-embajadas-y-consulados/argentina-decide-retirarse-de-las-negociaciones-externas-que-emprende-el-mercosur

Ministry of Business, Innovation and Employment (New Zeland). Trade agreements and partnerships. https://www.mbie.govt.nz/business-and-employment/business/trade-and-tariffs/trade-agreements-and-partnerships /

Ministry of Foreign Affairs and Trade (2020). New Zeland. Briefing to incoming Minister for Trade and Export Growth. https://www.mfat.govt.nz/assets/About-usCorporate/MFAT-corporate-publications/Briefings-to-incoming-Ministers/Briefing-for-incoming-Minister-for-Trade-and-Export-Growth-2020.pdf

- (2020) International Treaty Making - Guidance for government agencies on practice and procedures for concluding international treaties and arrangements. https:// www.mfat.govt.nz/assets/About-us-Corporate/Treaties-Model-instruments/International-Treaty-Making-Guide-2020.pdf

Naray, O. (2008), "Commercial diplomacy: a conceptual overview", Conference Paper, 7th World Conference of TPOs, La Haya. 
North, D. (1990) Institutions, Institutional Change and Economic Performance (Political Economy of Institutions and Decisions). Cambridge: Cambridge University Press.

OMC -Organización Mundial del Comercio-. (2020). Trade Policy 2020. Uruguay. https://www.wto.org/english/res_e/statis_e/daily_update_e/trade_profiles/ UY_e.pdf

- (2015) Examen de las Políticas Comerciales: Nueva Zelanda. Informe de la Secretaría. https://docs.wto.org/dol2fe/Pages/SS/directdoc.aspx?filename=s:/WT / TPR/S316R1.pdf\&Open=True

Palumbo, I. (3 de junio 2020). Uruguay debe abrirse al mundo, desarrollar su estrategia de inserción internacional y "deshacerse del corset" del MERCOSUR. Crónicas. http://www.cronicas.com.uy/sociedad/uruguay-debe-abrirse-al-mundo-desarrollar-su-estrategia-de-insercion-internacional-y-deshacerse-del-corset-del-mercosur/

Peters, B.G. (2018), “The Challenge of Policy Coordination”, Policy Design and Practice, vol. 1 núm 1.

Rebolledo, A., M. Montt, N. Albertoni y F. Muñoz (2019). "The Political Economy of Chile's Trade Policy." Banco Interamericano de Desarrollo, Washington, DC. Documento no publicado.

Sáez, S. (2005). Trade Policy Making in Latin America: A compared Analysis. Naciones Unidas. CEPAL. Division of International Trade and Integration. Serie Comercio Internacional No55. Santiago de Chile. https://repositorio.cepal.org/handle $/ 11362 / 4397$

UNCTAD (2018). Trade Policy Frameworks for Developing Countries: A Manual of Best Practices. Organización de Naciones Unidas.

URUGUAY XXI (2021), Informe Anual Comercio Exterior 2020. https://www.uruguayxxi.gub.uy/es/centro-informacion/articulo/informe-de-comercio-exterior-de-uruguay-2020/

- (2020) Informe de Comercio Exterior. Julio 2020. https://www.uruguayxxi.gub. uy/es/centro-informacion/articulo/informe-mensual-de-comercio-exterior-julio-2020/

- (2020) Informe Sectorial. Servicios Globales. Noviembre 2020. https://www.uruguayxxi.gub.uy/uploads/informacion/7cbf5241a54e71102be3ff9be689e12f0d6a fd11.pdf

- (2019). Informe de Comercio Exterior de Uruguay 2019. https://www.uruguayxxi. gub.uy/es/centro-informacion/articulo/informe-de-comercio-exterior-de-uruguay-2019

- (2017) Servicios Globales de Exportación en Uruguay. https://www.uruguayxxi. gub.uy/uploads/informacion/Informe\%20Servicios\%20Globales\%20-\%20Uruguay $\% 20 X X I \% 20-\% 20 F e b r e r o \% 202017-8 . p d f$

- (2017) Oportunidades de Inversión. Turismo. Marzo 2017. https://www.uruguayxxi.gub.uy/uploads/informacion/Informe\%20Turismo\%20Marzo\%20-\%20 2017\%20-\%20Uruguay\%20XXI_ES-4.pdf 
- Exportaciones por Destinos 2001-2020. https://www.uruguayxxi.gub.uy/es/centro-informacion/articulo/exportaciones-por-destinos/

Vachino, M. (1989). Esquemas Latinoamericanos de Integración-Problemas y desarrollos-. Pensamiento Iberoamericano, №15. Enero-Junio 1989.

Zelicovich, J. (2020). Anatomía de las instituciones de la Política Comercial Externa: Estudio de casos. Instituto para la Integración de América Latina y el Caribe (INTAL). Sector de Integración y Comercio (INT). Nota técnica N IDB-TN-1851. https:/ /publications.iadb.org/publications/spanish/document/Anatom\%C3\%ADa_de_las_ instituciones_de_la_pol\%C3\%ADtica_comercial_externa_Estudio_de_casos_es.pdf

Otros organismos consultados

- PARLAMENTO DE LA REPÚBLICA ORIENTAL DEL URUGUAY.

- ministerio DE GANADERÍA, AGRICULTURA y PESCA (MGAP)

- MINISTERIO DE INDUSTRIA, ENERGÍA Y MINERÍA (MIEM)

- MINISTERIO DE TURISMO (MINTUR)

- MINISTERIO DE AMBIENTE

- INSTITUTO NACIONAL DE LA CARNE (INAC)

- INSTITUTO NACIONAL DE LA LECHE (INALE)

- CÁMARA DE INDUSTRIAS DEL URUGUA (CIU)

- cámara nacional de COMERCIO y SERVICIOS (CNCS)

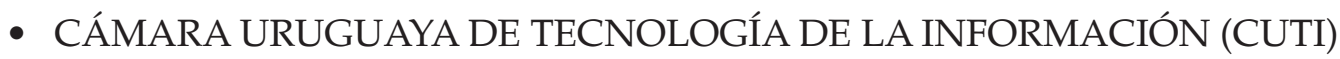

- ASOCIACIÓN RURAL DEL URUGAY (ARU)

- UNIÓN DE EXPORTADORES DEL URUGUAY (UEU)

- DIRECCIÓN NACIONAL DE IMPRESIONES Y PUBLICACIONES OFICIALES (IMPO)

- DIRECCIÓN NACIONAL DE ADUANAS

- OFICINA DE PLANEAMIENTO Y PRESUPUESTO (OPP)

Entrevistas realizadas

El trabajo de campo realizado pretendió incluir distintos actores de la actualidad o que, en el pasado, hayan ocupado posiciones clave dentro de la estructura de la política comercial. La cantidad de entrevistas y diversidad de las mismas han sido un elemento fundamental que nos ha permitido completar el estudio de la literatura existente con la experiencia práctica.

\section{- MINISTERIO DE RELACIONES EXTERIORES DEL URUGUAY}

- Embajadora Victoria Francolino - Directora General de Asuntos Económicos Internacionales

- Embajadora Valeria Csukasi - Directora Dirección Regional Asia, África y Oceanía

- Embajador Nelson Chaben - Embajador designado ante el Reino de Arabia Saudita

- Embajador Guillermo Valles - Embajador ante la República Federativa del Brasil 
- Embajador Fernando Lugris - Embajador ante la República Popular de China

- MINISTERIO DE ECONOMÍA Y FINANZAS

- Economista Juan Labraga - Director de la Asesoría de Política Comercial

- MINISTERIO DE GANADERÍA, AGRICULTURA Y PESCA

- Licenciada Adriana Lupinaci - Directora de Asuntos Internacionales

- MINISTERIO DE INDUSTRIA, ENERGÍA Y MINERÍA

- INSTITUTO NACIONAL DE LA CARNE

- Economista Alvaro Pereira Ramela - Jefe de Acceso e Inteligencia de Mercados (en coordinación con el Presidente de INAC, Ing. Agr. Fernando Mattos)

- INSTITUTO NACIONAL DE LA LECHE

- Economista Mercedes Baraibar - Información de Estudios Económicos

- CÁMARA DE INDUSTRIAS DEL URUGUAY

- UNIÓN DE EXPORTADORES

- Licenciada Andrea Roth - Presidente de la Unión de Exportadores

- URUGUAY XXI

- PIT-CNT

- Economista Pablo Da Rocha - Asesor del Departamento de Relaciones Internacionales.

- OTROS

- Embajador (retirado) - Elbio Roselli

- Economista Isidoro Hodara

- Doctor Andrés Rebolledo (Chile)

- Embajador Dr. Jorge Heine (Chile)

- Doctor en Ciencias Políticas y Relaciones Internacionales Nicolás Albertoni Investigador Académico y Prosecretario de Relaciones Internacionales del Partido Colorado

- Doctor en Economía Marcel Vaillant - Investigador Académico y asesor del Partido Independiente

- Economista Alvaro Ons - Ex Director de la APC del MEF, de la Dirección de Integración y Mercosur del MRREE

- Economista Mario Bergara - Senador del Frente Amplio 